\title{
Phylogeny of the Lobariaceae (lichenized Ascomycota: Peltigerales), with a reappraisal of the genus Lobariella
}

\author{
Bibiana MONCADA, Robert LÜCKING and Luisa BETANCOURT-MACUASE
}

\begin{abstract}
The generic classification of Lobariaceae based on a three-gene phylogeny of mtSSU, nuLSU and ITS data, with special reference to the genus Lobariella, is reassessed. Twelve wellsupported clades are recognized within Lobariaceae, which correlate with morpho-chemical and ecological features and are suggested to represent distinct generic lineages within the family. Lobaria s. lat. forms at least six lineages: Lobaria s. str. (type L. pulmonaria), the Pseudocyphellaria anomala group, for which the genus Anomalobaria is introduced (type A. anomala), Lobarina (type L. scrobiculata), Ricasolia (type R. amplissima; syn.: Dendriscocaulon), the Sticta wrightii group, for which the genus Dendriscosticta is introduced (type D. wrightii), the Lobaria peltigera group, for which the genus Yoshimuriella is introduced (type Y. fendleri), and Lobariella (type L. crenulata; syn: Durietzia nom. illeg.). Pseudocyphellaria s. lat. comprises four lineages, each of which having genus-level names available: Crocodia (type C. aurata), Parmostictina (type P. hirsuta), Podostictina (type P. endochrysoides), and Pseudocyphellaria (type $P$. crocata). The Pseudocyphellaria anomala group (Anomalobaria) comes out sister to Lobaria s. str., whereas Sticta s. lat. forms two unrelated lineages, Sticta s. str. (type $S$. sylvatica) and the $S$. wrightii group (Dendriscosticta), which is closely related to Lobariella and the Lobaria peltigera group (Yoshimuriella). Although these twelve clades can be organized into three larger clades that largely correspond to the traditional genera Lobaria, Pseudocyphellaria, and Sticta, the clade support for Pseudocyphellaria s. lat., as well as the distribution of morpho-chemical characters over the topology, does not favour such a conclusion. In particular, the most relevant characters traditionally used to separate these genera, pseudocyphellae and/or cyphellae, are found in at least two of the three larger clades (some species of Sticta having pseudocyphellae rather than cyphellae). The strongly supported Lobaria s. lat. clade includes species with and without cyphellae and pseudocyphellae (both on the lower side), which defies the traditional classification using these characters. Based on an expanded ITS phylogeny, Lobariella itself is emended to include 26 species, and a key is presented to all species. The following three genera and 19 species are described as new: Anomalobaria B. Moncada \& Lücking gen. nov., Dendriscosticta B. Moncada \& Lücking gen. nov., Yoshimuriella B. Moncada \& Lücking gen. nov., Lobariella angustata B. Moncada \& Lücking sp. nov., L. auriculata B. Moncada \& Lücking sp. nov., L. ecorticata B. Moncada \& Lücking sp. nov., $L$. flavomedullosa B. Moncada, Betancourt-Macuase \& Lücking sp. nov., L. isidiata B. Moncada \& Lücking sp. nov., L. nashii B. Moncada \& Lücking sp. nov., L. olivascens B. Moncada \& Lücking sp. nov., L. pallidocrenulata B. Moncada \& Lücking sp. nov., L. papillifera B. Moncada \& Lücking sp. nov., L. parmelioides B. Moncada \& Lücking sp. nov., L. peltata B. Moncada \& Lücking sp. nov., L. pseudocrenulata B. Moncada \& Lücking sp. nov., L. reticulata B. Moncada \& Lücking sp. nov., L. rugulosa B. Moncada \& Lücking sp. nov., L. soredians B. Moncada, Betancourt-Macuase \& Lücking sp. nov., L. spathulifera B. Moncada \& Lücking sp. nov., L. stenroosiae B. Moncada \& Lücking sp. nov., L. subcorallophora B. Moncada \& Lücking sp. nov., and L. subcrenulata B. Moncada \& Lücking sp. nov. Further, the following 15 new combinations are proposed: Anomalobaria anomala (Brodo \& Ahti) B. Moncada \& Lücking comb. nov. [Pseudocyphellaria anomala Brodo \& Ahti], A. anthraspis (Ach.) B. Moncada \& Lücking comb. nov. [Sticta anthraspis Ach.; Pseudocyphellaria anthraspis (Ach.) H. Magn.], Dendriscosticta platyphylla (Trevis.) B. Moncada \& Lücking comb. nov. [Lobaria platyphylla Trevis.; Sticta nylanderiana Zahlbr.], D. platyphylloides (Nyl.) B. Moncada \& Lücking comb. nov. [Sticta platyphylloides Nyl.], D. oroborealis (Goward \& Tønsberg) B. Moncada \& Lücking comb. nov. [Sticta oroborealis Goward \& Tønsberg], D. praetextata (Räsänen) B. Moncada \& Lücking comb. nov. [Sticta platyphylla var. praetextata Räsänen; S. praetextata (Räsänen) D. D. Awasthi], D. wrightii (Tuck.) B. Moncada \& Lücking comb. nov. [Sticta wrightii Tuck.], Lobariella corallophora (Yoshim.) B. Moncada \& Lücking comb. et stat. nov. [Lobaria exornata var. corallophora
\end{abstract}

B. Moncada and L. Betancourt-Macuase: Licenciatura en Biología, Universidad Distrital Francisco José de Caldas, Cra. 4 No. 26B-54, Torre de Laboratorios, Herbario, Bogotá, Colombia.

R. Lücking (corresponding author): Department of Botany, The Field Museum, 1400 South Lake Shore Drive, Chicago, Illinois 60605-2496, USA. Email: rlucking@fieldmuseum.org 
Yoshim.], Yoshimuriella carassensis (Vain.) B. Moncada \& Lücking comb. nov. [Lobaria carassensis Vain.], Y. corrosa (Ach.) B. Moncada \& Lücking comb. nov. [Sticta dissecta var. corrosa Ach.; Lobaria corrosa (Ach.) Vain.], Y. deplanata (Nyl.) B. Moncada \& Lücking comb. nov. [Ricasolia subdissecta $\mathrm{f}$. deplanata Nyl.; Lobaria deplanata (Nyl.) Yoshim.], Y. dissecta (Sw.) B. Moncada \& Lücking comb. nov. [Lichen dissectus Sw.; Lobaria dissecta (Sw.) Raeusch], Y. fendleri (Tuck. \& Mont.) B. Moncada \& Lücking comb. nov. [Sticta fendleri Tuck. \& Mont.; Lobaria fendleri (Tuck. \& Mont.) Lindau], Y. subcorrosa (Nyl.) B. Moncada \& Lücking comb. nov. [Ricasolia subcorrosa Nyl.; Lobaria subcorrosa (Nyl.) Vain.], and Y. subdissecta (Nyl.) B. Moncada \& Lücking comb. nov. [Ricasolia subdissecta Nyl.; Lobaria subdissecta (Nyl.) Vain.].

Key words: Brazil, Costa Rica, Colombia, Ecuador, faveolate, foveolate, isidia, lichen, phyllidia, scrobiculate, taxonomy

Accepted for publication 17 November 2012

\section{Introduction}

Lobariaceae is the second largest family of macrolichens in the Ascomycota, with close to 400 species currently accepted (Cannon \& Kirk 2007; Kirk et al. 2008). Recent molecular studies suggest that the family might contain a much larger number of species, probably close to 800 (Moncada \& Lücking 2012). Lobariaceae includes some of the most conspicuous macrolichens, with thalli up to $50 \mathrm{~cm}$ or more in diameter. Most workers divide the family into three large genera (Cannon \& Kirk 2007; Galloway 2007; Kirk et al. 2008): Sticta (with cyphellae on the lower side), Pseudocyphellaria (with pseudocyphellae on the lower side), and Lobaria (lacking cyphellae and pseudocyphellae on the lower side).

Attempts have been made to split these genera into smaller, more natural entities, among them the genus Lobariella, characterized by a maculate to pseudocyphellate upper surface and a lower tomentum composed of hyphae with rounded cells (Yoshimura 1971, 1984, 1998a, b, 2002; Yoshimura \& Arvidsson 1994). This genus was first segregated from Lobaria under the name Durietzia (Yoshimura 1998a, b); however, Durietzia is an illegitimate later homonym of Durietzia Gyeln. (Gyelnik 1935), a synonym of Ionaspis Th. Fr. in the Hymeneliaceae, and therefore the genus name was replaced with Lobariella (Yoshimura 2002). Another reinstated segregate genus is Lobarina Nyl. ex Cromb. (Yoshimura 1998a, b), which comprises the Lobaria scrobiculata group and is characterized by scrobiculate lobes with reduced lower cortex, and an unusual chemistry of usnic acid in the cortex and the stictic and norstictic acid chemosyndrome in the medulla (Yoshimura $1998 a$, 2004). Furthermore, Jørgensen \& Galloway (2011) and J. A. Elix \& D. J. Galloway (unpublished data) have suggested splitting Pseudocyphellaria into at least two genera, proposing to conserve Pseudocyphellaria for the larger $P$. crocata clade (with a conserved type) and to use Crocodia for the small $P$. aurata clade. The few molecular phylogenetic studies available for this family did not provide conclusive evidence for either maintaining three large or accepting several smaller genera, although there was some indication that Lobaria s. lat., Pseudocyphellaria s. lat., and Sticta s. lat. are all, to some extent, para- or polyphyletic (Miądlikowska et al. 2002; Thomas et al. 2002; Stenroos et al. 2003; Wiklund \& Wedin 2003; Miądlikowska \& Lutzoni 2004; Takahashi et al. 2006; Högnabba et al. 2009).

Lobariella itself, comprising the Lobaria crenulata group, until recently included five species, distinguished by the nature of the photobiont, the reproductive mode, and the development of the upper surface maculae and/or pseudocyphellae (Yoshimura 1984, 1998a, b, 2002; Yoshimura \& Arvidsson 1994): L. crenulata (Hook.) Yoshim. (green algae, apothecia, pseudocyphellae), L. pallida (Hook.) Moncada \& Lücking (green algae, apothecia, maculae), L. exornata (Zahlbr.) Yoshim. (green algae, cylindrical isidia, pseudocyphellae), L. subexornata (Yoshim.) 
Yoshim. (green algae, applanate isidia, pseudocyphellae), and L. botryoides (Yoshim. \& Arv.) Moncada \& Lücking (cyanobacteria, dactyliform soralia, maculae). A sixth species, L. sipmanii Moncada et al., was described from Colombia, characterized by a cyanobacterial photobiont, apothecia, and reticulate maculae (Lumbsch et al. 2011). Yet Lobariella continued to be considered a small genus within the family. In contrast to the large genera Lobaria, Pseudocyphellaria and Sticta, Lobariella appears to have a restricted, neotropical distribution, being known from Mexico to southern Brazil, although L. crenulata has been reported from as far as Hawaii (Yoshimura 1984, 1998a, b, 2002; Yoshimura \& Arvidsson 1994).

In this study, we re-examined the molecular phylogeny of the family Lobariaceae, in order to test the taxonomic status of Lobariella and other potential segregate genera of Lobaria s. lat., Pseudocyphellaria s. lat., and Sticta s. lat. We also examined a fairly large number of new Lobariella collections, focusing on Colombia and Costa Rica, and generated ITS sequences for selected specimens. Our results suggest that Lobariaceae can be divided into 12 genera, each delimited by a combination of morphological and chemical features, and that the genus Lobariella is more highly speciose than previously thought, with 19 new species described herein and a total of 26 species accepted.

\section{Material and Methods}

Fresh material for this study was collected by us during fieldwork in Colombia, Costa Rica, Ecuador and Brazil, mostly within the framework of a systematic revision of the lichen genus Sticta in Colombia by BM, a neotropical workshop project by RL, and an ecological study of Colombian páramos by LB. In addition, we revised herbarium specimens housed at the Universidad Distrital Francisco José Caldas (UDBC), the national herbarium of Colombia at the Universidad Nacional (COL), the collection at the Instituto Nacional de Biodiversidad in Costa Rica (INB), and collections from several parts of the Neotropics at Arizona State University (ASU) and the Field Museum of Natural History (F). We also examined voucher specimens of sequences deposited in GenBank (mostly from $\mathrm{H}$ ), as well as type material of most of the species.
The specimens were studied at the Universidad Distrital Francisco José de Caldas and at The Field Museum using standard techniques of light microscopy and thinlayer chromatography (Orange et al. 2001; Lumbsch 2002). For TLC, we used solvent C (170 ml toluene, $30 \mathrm{ml}$ glacial acetic acid), following Yoshimura (1984) and Yoshimura \& Arvidsson (1994). We used the term chemosyndrome to classify different sets of chemical substances occurring together, following the definition in the LIAS glossary [http://glossary.lias.net/wiki/ Chemosyndrome]: "chemosyndrome (noun, pl. chemosyndromes) - a biogenetically meaningful set of major and minor natural metabolic products produced by a species".

A standardized protocol of morphological, anatomical, and chemical characters was used to describe each specimen, adapted from a larger protocol to study phenotypic variation in the genus Sticta (Moncada 2012). Among these characters, we define the uneven lobe surface structure found in many Lobariaceae as follows (see also Harris 1979; http://ants.csiro.au/Surface_ Sculpturing):

- faveolate: with large, deep depressions narrowly separated by sharp ridges, as for example in Lobaria pulmonaria;

- foveolate (pitted): with small, deep depressions widely separated by otherwise even thallus, as for example in Sticta kunthii;

- scrobiculate: with large, shallow depressions narrowly separated by rounded ridges, as for example in Lobaria scrobiculata.

These terms have been used interchangeably in the literature and are often confused, especially the very similar-sounding terms faveolate and foveolate, but the definition above follows that proposed by Galloway (1988, 1992, 1997, 2007) and other workers. We also defined vegetative propagules as follows:

- isidia: cylindrical or flattened but then with both sides similar;

- phyllidia: flattened with both sides differentiated.

DNA extraction and sequencing was performed by $\mathrm{BM}$ at the Pritzker Laboratory for Molecular Systematics and Evolution at the Field Museum of Natural History. Sequences of the internal transcribed spacer (ITS), the mitochondrial small subunit rDNA (mtSSU), and the nuclear large subunit rDNA (nuLSU) were targeted for selected specimens of Lobariella, Lobaria, Pseudocyphellaria, and Sticta, and a total of 57 new sequences were generated for this study (Table 1). DNA was extracted using the QIAGEN DNeasy Plant Mini Kit. Dilutions of 10:1 up to 10:2 were used for PCR amplifications, with the primer pairs ITS1F and ITS4 for the ITS (White et al. 1990; Gardes \& Bruns 1993), mrSSU1 and MSU7 for the mtSSU (Zoller et al. 1999; Zhou \& Stanosz 2001), and AL2R and LR6 for the nuLSU (Vilgalys \& Hester 1990; Mangold et al. 2008). The 25 $\mu 1$ PCR reactions contained $2.5 \mu \mathrm{l}$ buffer, $2.5 \mu \mathrm{dNTP}$ mix, $1 \mu \mathrm{l}$ of each primer $(10 \mu \mathrm{M}), 5 \mu \mathrm{l}$ BSA, $2 \mu \mathrm{l}$ Taq, $2 \mu \mathrm{l}$ genomic DNA extract and $9 \mu \mathrm{l}$ distilled water. The 
TABLE 1. Genbank numbers of specimens and sequences used in the phylogenetic analyses. All corresponding sequences were used in the individual gene tree analyses (mtSSU, nuLSU, ITS) and sequences marked with an asterisk* were used in the combined analysis. All Lobariella ITS sequences were used in the Lobariella ITS analysis. Sequences marked with two asterisks** were excluded from the analysis due to quality problems. Voucher information is given for all newly generated sequences and for all Lobariella samples.

\begin{tabular}{|c|c|c|c|c|c|c|}
\hline Species & $\mathrm{mtSSU}$ & nuLSU & ITS & Country & Collector & Number \\
\hline Nephroma antarcticum* & EU558818 & EU558743 & & & & \\
\hline N. arcticum 1 & & AF286828 & & & & \\
\hline N. arcticum 2 & AY124171 & & & & & \\
\hline N. arcticum 3 & AY124172 & & & & & \\
\hline N. $\operatorname{arcticum} 4^{*}$ & DQ972989 & DQ973040 & & & & \\
\hline N. arcticum 5 & EU558819 & & & & & \\
\hline N. bellum $1^{*}$ & AY 124177 & AY424211 & & & & \\
\hline N. bellum 2 & AY124178 & & & & & \\
\hline N. bellum 3 & AY300895 & & & & & \\
\hline N. bellum 4 & EU558820 & EU360859 & & & & \\
\hline N. bellum 5 & & EU558744 & & & & \\
\hline N. cellulosum & AY124173 & & & & & \\
\hline N. expallidum 1 & AY124179 & & & & & \\
\hline N. expallidum 2 & AY124180 & & & & & \\
\hline N. helveticum $1 *$ & AY124174 & & AY124123 & & & \\
\hline N. helveticum 2 & AY124175 & & & & & \\
\hline N. helveticum 3 & AY124176 & & & & & \\
\hline N. laevigatum 1 & AY124181 & & & & & \\
\hline N. laevigatum 2 & AY124182 & & & & & \\
\hline N. parile $1^{*}$ & AY124183 & AY340557 & & & & \\
\hline N. parile 2 & AY124184 & & & & & \\
\hline N. parile 3 & AY340512 & & & & & \\
\hline N. parile 4 & AY584625 & & & & & \\
\hline N. resupinatum 1 & & AF286829 & & & & \\
\hline N. resupinatum 2 & & AF286830 & & & & \\
\hline N. resupinatum 3 & AY124168 & & & & & \\
\hline N. resupinatum 4 & AY124169 & & & & & \\
\hline N. resupinatum 5 & AY124170 & & & & & \\
\hline$N$. tangeriense & AY124185 & & & & & \\
\hline Dendriscocaulon sp. & & & AB239337 & & & \\
\hline D. sp.* & AY124158 & & AB239338 & & & \\
\hline D. sp. & & & AB239340 & & & \\
\hline Lobaria adscripta* & & & AF350296 & & & \\
\hline L. amplissima $1 *$ & AY340500 & AY340546 & AF524923 & & & \\
\hline L. amplissima 2 & AY340501 & AY340547 & & & & \\
\hline L. amplissima 3 & & AY424206 & & & & \\
\hline L. amplissima 4 & & EU360856 & & & & \\
\hline L. amplissima 5 & EU558805 & EU558748 & & & & \\
\hline L. amplissima 6 & EU558806 & EU558749 & & & & \\
\hline
\end{tabular}


TABle 1. Continued

\begin{tabular}{|c|c|c|c|c|c|c|}
\hline Species & $\mathrm{mtSSU}$ & nuLSU & ITS & Country & Collector & Number \\
\hline Lobaria amplissima 7 & EU558807 & EU558750 & & & & \\
\hline L. dissecta* & EU558808 & EU558746 & AF524920 & & & \\
\hline L. hallii 1 & AY340502 & AY424204 & & & & \\
\hline L. hallii 2 & GQ259034 & GQ259004 & & & & \\
\hline L. immixta* & & & FJ649580 & & & \\
\hline L. isidiosa* & & & EU627000 & & & \\
\hline L. kurokawae 2 & & DQ448649 & & & & \\
\hline L. kurokawae 3 & & DQ448651 & & & & \\
\hline L. kurokawae 4 & & DQ448654 & & & & \\
\hline L. kurokawae 5 & & DQ448655 & & & & \\
\hline L. linita $1^{*}$ & EU558809 & EU558800 & AB239702 & & & \\
\hline L. linita 2 & GQ259035 & GQ259005 & & & & \\
\hline L. macaronesica* & & & FJ649596 & & & \\
\hline L. oregana 1 & & AY424203 & & & & \\
\hline L. oregana $2^{*}$ & & $\mathrm{EF} 605271$ & EF605270 & & & \\
\hline L. orientalis* & EU558810 & EU558796 & DQ001290 & & & \\
\hline L. pseudopulmonaria $1^{*}$ & & DQ448646 & DQ419925 & & & \\
\hline L. pseudopulmonaria 2 & & DQ448647 & & & & \\
\hline L. pulmonaria $1^{*}$ & AF069541 & AF183934 & AF129284 & & & \\
\hline L. pulmonaria 2 & & AF401965 & & & & \\
\hline L. pulmonaria 3 & & $\mathrm{AF} 401965$ & & & & \\
\hline L. pulmonaria 4 & AY340503 & AY340548 & & & & \\
\hline L. pulmonaria 5 & AY340504 & AY340549 & & & & \\
\hline L. pulmonaria 6 & EU558811 & EU558797 & & & & \\
\hline L. pulmonaria 7 & EU558812 & EU558798 & & & & \\
\hline L. pulmonaria 8 & EU558813 & EU558799 & & & & \\
\hline L. quercizans $1^{*}$ & AY584710 & AF279397 & AF524921 & & & \\
\hline L. quercizans 2 & EU558814 & EU558747 & & & & \\
\hline L. retigera $1^{*}$ & AY124159 & AY340550 & AY124094 & & & \\
\hline L. retigera 2 & AY 124160 & & & & & \\
\hline L. retigera 3 & AY340505 & & & & & \\
\hline L. retigera 4 & & DQ448644 & & & & \\
\hline L. retigera 5 & & DQ448648 & & & & \\
\hline L. retigera 6 & & DQ448650 & & & & \\
\hline L. retigera 7 & & DQ448652 & & & & \\
\hline
\end{tabular}




\begin{tabular}{|c|c|c|c|c|c|c|}
\hline Species & $\mathrm{mtSSU}$ & nuLSU & ITS & Country & Collector & Number \\
\hline Lobaria scrobiculata 2 & AY340507 & AY340552 & & & & \\
\hline L. scrobiculata 3 & AY584621 & AY424205 & & & & \\
\hline L. scrobiculata 4 & & EU360857 & & & & \\
\hline L. scrobiculata 5 & EU558816 & EU558787 & & & & \\
\hline L. silvaeveteris* & & & AF014110 & & & \\
\hline L. spathulata* & & & DQ394371 & & & \\
\hline L. subdissecta* & KC011073 & KC011022 & KC011029 & Colombia & Moncada & 3152 \\
\hline L. virens* & AY340508 & AY340553 & & & & \\
\hline Lobariella angustata 1 & & & KC011030 & Colombia & Vargas $\mathcal{E}$ Herrera & $310 \mathrm{a}$ \\
\hline L. angustata 2 & & & KC011031 & Colombia & Vargas $\mathcal{E}$ Herrera & $281 \mathrm{a}$ \\
\hline L. auriculata* & & & KC011032 & Colombia & Moncada & 3075 \\
\hline L. botryoides* & & & KC011033 & Colombia & Moncada & s.n. \\
\hline L. crenulata & & & KC011034 & Colombia & Diáz E Soto & L9 \\
\hline L. ecorticata & & & KC011035 & Colombia & Moncada & 3156 \\
\hline L. exornata & & & KC011038 & Colombia & Diáz E্ Soto & L12 \\
\hline L. flavomedullosa $1^{*}$ & & & KC011036 & Colombia & Moncada & s.n. \\
\hline L. flavomedullosa 2 & & & KC011037 & Colombia & Moncada & s.n. \\
\hline L. flavomedullosa 3* & KC011074 & & & Colombia & Rodríguez E Zárate & 37 \\
\hline L. nashii & EU558804 & EU558770 & AF524902 & Mexico & Nash & 42486 \\
\hline L. pallida $1^{*}$ & DQ912296 & DQ883796 & HQ650695 & Costa Rica & Lutzoni et al. & s.n. \\
\hline L. pallida 2 & & & KC011043 & Colombia & Moncada & 5353 \\
\hline L. pallida 3 & & & KC011039 & Colombia & Lücking & 33379 \\
\hline L. pallida 4 & & & KC011044 & Colombia & Moncada & 5349 \\
\hline L. pallida 5 & & & KC011045 & Colombia & Moncada & 5352 \\
\hline L. pallida 6 & & & KC011046 & Colombia & Moncada & 5350 \\
\hline L. pallida 7 & & & KC011040 & Colombia & Lücking & $33311 b$ \\
\hline L. pallida 8 & & & KC011042 & Colombia & Moncada & 5354 \\
\hline L. pallidocrenulata $1^{*}$ & KC011075 & KC011023 & KC011051 & Colombia & Lücking & $33371 \mathrm{a}$ \\
\hline L. pallidocrenulata 2 & & & KC011055 & Colombia & Diáz É Soto & L10 \\
\hline L. pallidocrenulata 3 & & & KC011050 & Colombia & Moncada & 3164 \\
\hline L. pallidocrenulata 4 & & & KC011048 & Colombia & Moncada & 4078 \\
\hline L. pallidocrenulata 5 & & & KC011049 & Colombia & Moncada & 4709 \\
\hline L. pallidocrenulata 6 & & & KC011053 & Colombia & Lücking & $33354 a$ \\
\hline L. pallidocrenulata 7 & & & KC011047 & Colombia & Lücking & $33371 \mathrm{c}$ \\
\hline L. pallidocrenulata 8 & & & KC011052 & Colombia & Lücking & $33371 b$ \\
\hline L. pallidocrenulata 9 & & & KC011054 & Colombia & Lücking & $33354 b$ \\
\hline L. parmeloidides 1 & & & KC011056 & Colombia & Moncada & 5351 \\
\hline L. parmeloidides 2 & & & KC011057 & Colombia & Moncada & 5356 \\
\hline L. parmeloidides 3 & & & KC011058 & Colombia & Moncada & 5358 \\
\hline L. parmeloidides 4 & & & KC011059 & Colombia & Moncada & 5357 \\
\hline L. parmeloidides 5 & & & KC011060 & Colombia & Moncada & 5355 \\
\hline
\end{tabular}


TABle 1. Continued

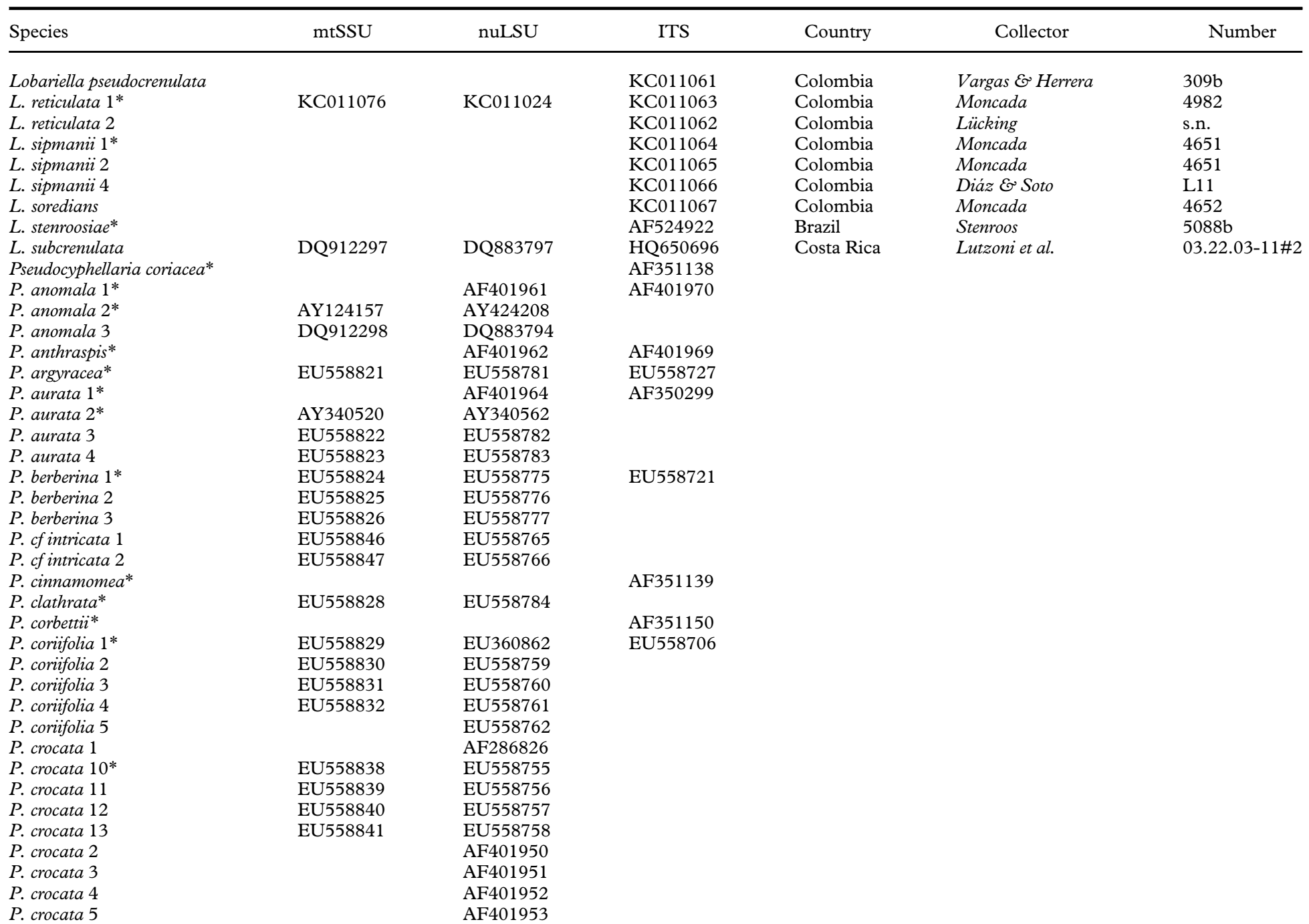




\begin{tabular}{|c|c|c|c|c|c|c|}
\hline Species & $\mathrm{mtSSU}$ & nuLSU & ITS & Country & Collector & Number \\
\hline Pseudocyphellaria crocata $6^{*}$ & AY340521 & AY340563 & AJ437682 & & & \\
\hline P. crocata 7 & EU558833 & EU558751 & & & & \\
\hline P. crocata 8 & EU558834 & EU558752 & & & & \\
\hline P. crocata 9 & EU558836 & EU558754 & & & & \\
\hline P. divulsa* & AY340522 & AY340564 & & & & \\
\hline P. dubia* & GQ259042 & & & & & \\
\hline P. endochrysa* & EU558842 & EU558779 & & & & \\
\hline P. episticta* & & & AF351152 & & & \\
\hline P. faveolata* & & & AF350311 & & & \\
\hline P. fimbriatoides* & & & AF351143 & & & \\
\hline P. freycinetii $1^{*}$ & EU558827 & EU360863 & EU558717 & & & \\
\hline P. freycinetii 2 & EU558843 & EU558771 & & & & \\
\hline P. freycinetii 3 & & EU558778 & & & & \\
\hline P. hirsuta $1^{*}$ & EU558844 & EU558763 & EU558710 & & & \\
\hline P. hirsuta 2 & EU558845 & EU558764 & & & & \\
\hline P. hookeri* & & & AF350315 & & & \\
\hline P. intricata* & EU558848 & EU558780 & AF351148 & & & \\
\hline P. lechleri* & EU558849 & EU558769 & EU558716 & & & \\
\hline P. mallota $1^{*}$ & EU558850 & EU558768 & & & & \\
\hline P. mallota 2 & EU558851 & EU558801 & & & & \\
\hline P. rufovirescens* & & & AF350316 & & & \\
\hline P. obvoluta $1^{*}$ & EU558852 & EU558785 & EU558730 & & & \\
\hline P. obvoluta 2 & EU558853 & EU558786 & & & & \\
\hline P. perpetua $1^{*}$ & & AF401954 & AF401971 & & & \\
\hline P. perpetua 2 & & AF401955 & & & & \\
\hline P. perpetua 3 & & AF401956 & & & & \\
\hline P. perpetua 4 & & AF401957 & & & & \\
\hline P. perpetua 5 & & AF401958 & & & & \\
\hline P. perpetua 6 & & AF401959 & & & & \\
\hline P. perpetua 7 & & AF401960 & & & & \\
\hline P. perpetua $8^{*}$ & EU558835 & EU558753 & & & & \\
\hline P. perpetua 9 & EU558837 & EU558803 & & & & \\
\hline P. pickeringii* & & & AF350301 & & & \\
\hline P. pilosella* & EU558854 & EU558802 & EU558740 & & & \\
\hline P. rainierensis* & & & AF401968 & & & \\
\hline P. scabrosa* & EU558855 & & EU558720 & & & \\
\hline P. sp. 1 & EU558856 & EU558772 & & & & \\
\hline P. sp. 2 & EU558857 & EU558773 & & & & \\
\hline Sticta beauvoisii* & DQ986867 & DQ986769 & & & & \\
\hline S. canariensis* & AY340527 & AY340570 & & & & \\
\hline S. carolinensis* & & & AY173379 & & & \\
\hline
\end{tabular}


TABle 1. Continued

\begin{tabular}{|c|c|c|c|c|c|c|}
\hline Species & $\mathrm{mtSSU}$ & nuLSU & ITS & Country & Collector & Number \\
\hline Sticta caulescens* & EU558858 & EU558793 & & & & \\
\hline S. cometiella* & KC011077 & KC011025 & KC011068 & Colombia & Moncada & 4152 \\
\hline S. damicornis* & EU558859 & & EU558731 & & & \\
\hline S. filix* & AY340528 & AY340571 & AF350304 & & & \\
\hline S. fuliginosa 1 & & AF286825 & & & & \\
\hline S. fuliginosa 2 & AY124161 & & & & & \\
\hline S. fuliginosa 3 & AY340529 & AY340572 & & & & \\
\hline S. fuliginosa 4 & AY340530 & AY340573 & & & & \\
\hline S. fuliginosa 5 & & DQ448656 & & & & \\
\hline S. fuliginosa $6^{*}$ & KC011078 & KC011026 & KC011069 & Wales & Chambers & s.n. \\
\hline S. gaudichaldia* & EU558860 & EU558792 & & & & \\
\hline S. gyalocarpa* & KC011079 & KC011027 & KC011070 & Colombia & Fonseca & 33 \\
\hline S. humboldti ${ }^{*}$ & & & KC011071 & Colombia & Moncada & 4614 \\
\hline S. hypochra 1 & & EU360864 & & & & \\
\hline S. hypochra 2 & & EU360865 & & & & \\
\hline S. hypochra 3 & & EU558767 & & & & \\
\hline S. hypochra 4 & EU558861 & EU558788 & & & & \\
\hline S. hypochra 5 & EU558862 & EU558789 & & & & \\
\hline S. hypochra 6 & EU558863 & EU558790 & & & & \\
\hline S. hypochra $7^{*}$ & EU558864 & EU558791 & EU558732 & & & \\
\hline S. impressula* & KC011080 & KC011028 & KC011072 & Colombia & Moncada & s.n. \\
\hline S. limbata $1^{*}$ & AY340531 & AY340574 & & & & \\
\hline S. limbata 2 & & AY424207 & & & & \\
\hline S. nylanderiana* & & & AB245121 & & & \\
\hline S. oroborealis* & & & AF208015 & & & \\
\hline S. praetextata* & & & AB245122 & & & \\
\hline S. weigelii* & EU558865 & EU558794 & $\mathrm{AB} 245124$ & & & \\
\hline S. wrightii & & & AB239339 & & & \\
\hline S. wrightii & & & AB239341 & & & \\
\hline S. wrightii & & & AB239342 & & & \\
\hline S. wrightii & & & AB329343 & & & \\
\hline S. wrightii* & & & AB239344 & & & \\
\hline S. wrightii & & & JQ673466 & & & \\
\hline
\end{tabular}


thermal cycling parameters were set as follows: initial denaturation for $3 \mathrm{~min}$ at $95^{\circ} \mathrm{C}$, followed by 30 cycles of $1 \mathrm{~min}$ at $95^{\circ} \mathrm{C}, 1 \mathrm{~min}$ at $52^{\circ} \mathrm{C}, 1 \mathrm{~min}$ at $73^{\circ} \mathrm{C}$, and final elongation for $7 \mathrm{~min}$ at $73^{\circ} \mathrm{C}$. Amplification products were mounted on $1 \%$ agarose gels stained with ethidium bromide and, after cutting of the target bands, purified using the QIAGEN QIAquick PCR Purification Kit or Nucleo Spin DNA purification kit (Macherey-Nagel). Fragments were sequenced using the Big Dye Terminator reaction kit (ABI PRISM, Applied Biosystems). Sequencing and PCR amplifications were performed using the same sets of primers. Cycle sequencing was executed with the following setting: 25 cycles of $95^{\circ} \mathrm{C}$ for $30 \mathrm{~s}, 48^{\circ} \mathrm{C}$ for $15 \mathrm{~s}, 60^{\circ} \mathrm{C}$ for $4 \mathrm{~min}$. Sequenced products were precipitated with $10 \mu \mathrm{l}$ of sterile $\mathrm{dH}_{2} \mathrm{O}$, $2 \mu \mathrm{l}$ of $3 \mathrm{M}$ Napa, and $50 \mu \mathrm{l}$ of $95 \% \mathrm{EtOH}$, and subsequently loaded on an ABI 3100 (Applied Biosystems) automatic sequencer. Sequence fragments obtained were assembled with DNASTAR SeqMan 4.03, manually inspected and adjusted, and submitted to GenBank (Table 1).

The sequences obtained for each gene were aligned with selected sequences of Lobariaceae from GenBank, using the genus Nephroma (Nephromataceae) as an outgroup (Table 1). We first downloaded all available sequences from GenBank for each gene and aligned and analyzed them separately to detect potentially inconsistent and problematic GenBank entries. From these, we selected one specimen per species that, if possible, had two or three genes available and was consistent in its phylogenetic placement in the separate gene trees. In two cases (Pseudocyphellaria crocata s. lat.), we included two samples per taxon in the final analysis to illustrate problems with inconsistent taxon identification in GenBank sequence entries. Alignments for each gene were assembled separately in BIOEDIT 7.0.9 (Hall 1999) and automatically pre-aligned using CLUSTALW2 (Thompson et al. 1994) to detect problematic sequences such as reverse complements. Final alignments were made with MAFFT $6.850 \mathrm{~b}$ (Katoh $e t$ al. 2002, 2009) using the -auto option. The alignments were submitted to the GUIDANCE server to delimit potential regions of alignment uncertainty (Penn et al. $2010 a, b$ ), and three ambiguously aligned regions of the mtSSU gene were removed and recoded with PICSORD (Lücking et al. 2011). The separate gene trees were tested for supported topological conflicts (MasonGamer \& Kellogg 1997; Miądlikowska \& Lutzoni 2000; Kauff \& Lutzoni 2002) and the three datasets were eventually combined into a single supermatrix of 2413 base lengths plus 50 PICS-Ord codes. The combined alignment included 91 terminal units, 28 of which were represented by three genes, 35 by two genes, and 28 by a single gene (Table 1). For the separate study of Lobariella, we assembled all available ITS sequences, using three species of the Lobaria peltigera group (sister group to Lobariella) as an outgroup (Table 1). The ITS alignment did not exhibit substantial ambiguously aligned regions and thus no portions were recoded or removed, other than gapped columns including single, non-parsimonious base insertions. We also computed a small tree including all available ITS sequences of Sticta wrightii s. lat., including its dendriscocauloid cyanomorphs (Table 1).

Phylogenetic analysis was performed on each gene and on the combined dataset using maximum likelihood in RAxML 7.2.6 (Stamatakis 2006; Stamatakis et al. 2008), applying the GTR-Gamma model and 500 bootstrap replicates. For the combined dataset including PICS-Ord codes, a mixed model was used with a general GTR model applied to the PICS-Ord code partition. All trees were visualized in FIGTREE 1.3.1. (Drummond \& Rambaut 2007).

\section{Results}

Phylogenetic analysis of the combined dataset resolved three large clades (Fig. 1A \& B): Lobaria s. lat., with strong support, Sticta s. str., with strong support, and Pseudocyphellaria s. lat., without support. Both Lobaria s. lat. (Fig. 1A) and Pseudocyphellaria s. lat. (Fig. 1B) comprise several well-supported subclades: Pseudocyphellaria s. lat. can be divided into the $P$. endochrysa, $P$. aurata, $P$. hirsuta, and P. crocata groups, whereas Lobaria s. lat. comprises the Pseudocyphellaria anomala group, Lobaria s. str., the L. scrobiculata, L. quercizans, and L. peltigera groups, as well as the Sticta wrightii group and Lobariella. Lobaria s. str. contains two larger subclades, the mostly Eastern Hemisphere L. retigera subclade and the mostly Western Hemisphere L. pulmonaria subclade. A similar topology is seen in the Sticta wrightii group, with the mostly Eastern Hemisphere $S$. nylanderiana and the mostly Western Hemisphere $S$. wrightii clade.

Analysis of the mtSSU dataset resulted in four clades within Lobariaceae (Fig. 2A): Sticta s. str., the Pseudocyphellaria endochrysa group, Lobaria s. lat. including the Sticta wrightii group, and the residual Pseudocyphellaria. In the nuLSU dataset (Fig. 2B), Lobaria s. str. and the Pseudocyphellaria anomala group form a basally diverging clade sister to two clades formed of Lobaria s. lat. (including the Sticta wrightii group) on one hand and Sticta s. str. and Pseudocyphellaria (excluding the $P$. anomala group) on the other. The ITS tree (Fig. 2C) looks similar to the $\mathrm{mtSSU}$ tree in the basally diverging Sticta s. str. and Pseudocyphellaria endochrysa groups, but Lobaria s. lat. is divided into Lobaria s. str. 


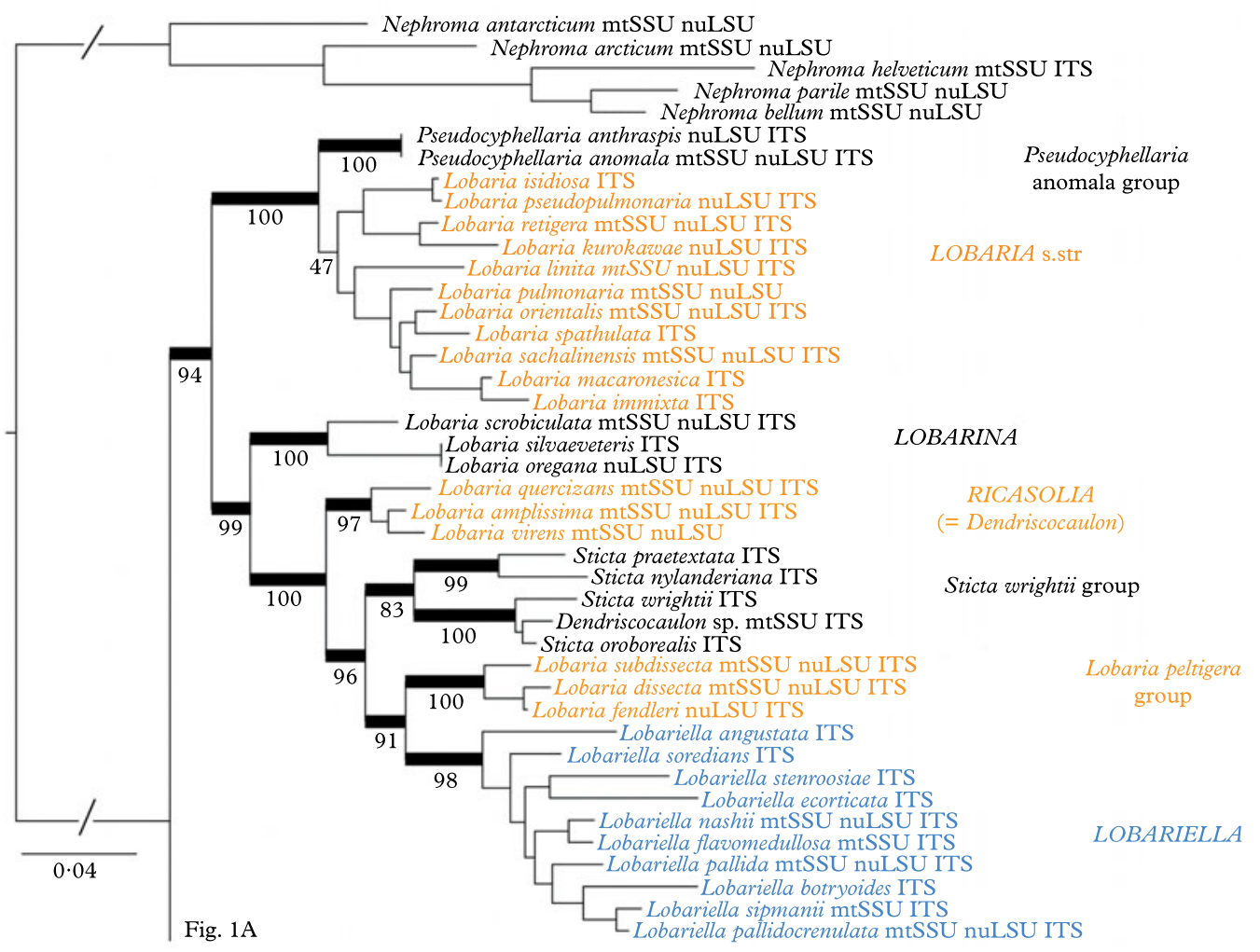

FIG. 1. Molecular 3-gene tree (mtSSU, nuLSU, ITS) of the lichen family Lobariaceae, reconstructed by means of a maximum likelihood approach in RAxML. Supported branches are indicated by thick lines and bootstrap support values are given. Putative genus-level clades are highlighted. In colour online.

plus the Pseudocyphellaria anomala group, sister to the $P$. crocata group, and the residual Lobaria s. lat. including the $S$. wrightii group, sister to the residual Pseudocyphellaria.

Separate analysis of the complete ITS data of 41 specimens of Lobariella, with the Lobaria peltigera group as outgroup, suggested the distinction of at least 17 species based on molecular data (Fig. 3). This was confirmed by morphological and ecological data, including thallus and lobe configuration, the morphology of the vegetative propagules, the lower tomentum, and secondary chemistry. The species are treated and discussed in detail below. There was no indication that species with similar gross morphology are closely related; on the contrary, certain characters appear to have evolved several times in parallel in the genus, such as flattened isidia and phyllidia in L. auriculata, L. ecorticata, L. nashii, and L. stenroosiae, or soralia in L. botryoides and L. soredians (Fig. 3). Both ecology and secondary chemistry appear to correlate well with major clades: the entire clade centred around L. pallida and L. sipmanii, although not supported, is characterized by gyrophoric acid as the major medullary substance (chemosyndrome A; see below), whereas most species outside this clade have an unidentified substance as the major compound (chemosyndrome B; see below). Also, the L. pallida clade is chiefly found in the páramo region, whereas most species outside this clade are more characteristic of montane to upper montane rain and cloud forest. 


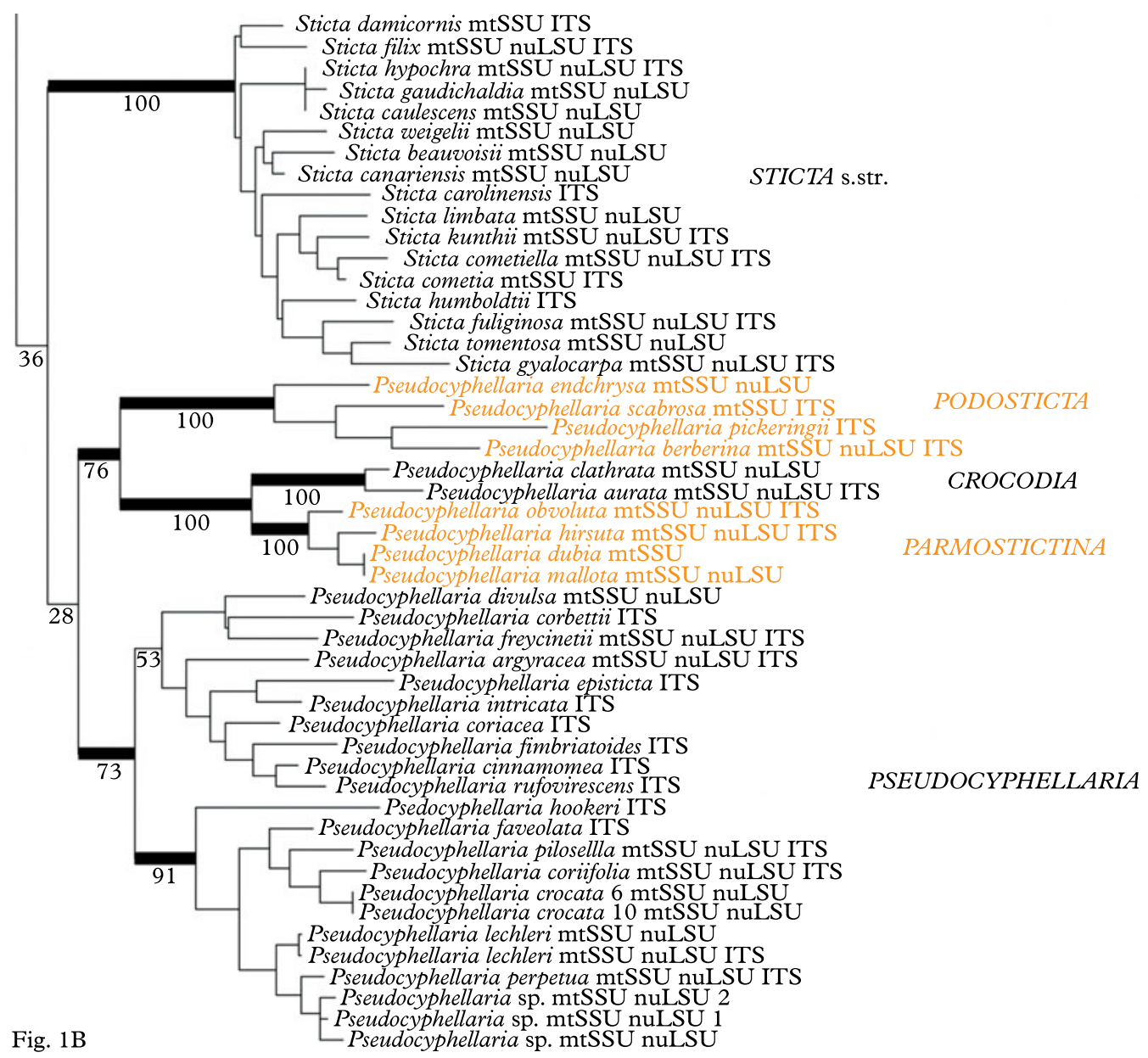

Fig. 1. Continued

\section{Discussion}

This study is the first comprehensive phylogenetic analysis of the Lobariaceae and the genus Lobariella using a combination of three genes and a robust phylogenetic maximum likelihood approach. Previous studies have used a smaller taxon sampling and/or fewer genes, such as either ITS or nuSSU plus nuLSU, or mtSSU plus nuLSU (Miądlikowska et al. 2002; Thomas et al. 2002; Stenroos et al. 2003; Wiklund \& Wedin 2003; Miadlikowska \& Lutzoni 2004; Cornejo \& Scheidegger 2010). Högnabba et al. (2009) used a dataset of similar size and with the same genes, but analyzed their data with direct optimization under a maximum parsimony model, which makes a direct comparison with our study difficult, particularly with regard to clade support. Nevertheless, many of the relationships found in our analysis agree with those recovered in previous studies, although better resolution and support was achieved with the maximum likelihood approach including ambiguous region coding employed here.

Whereas most previous studies suggested the traditional genera Lobaria s. lat., Pseudo- 

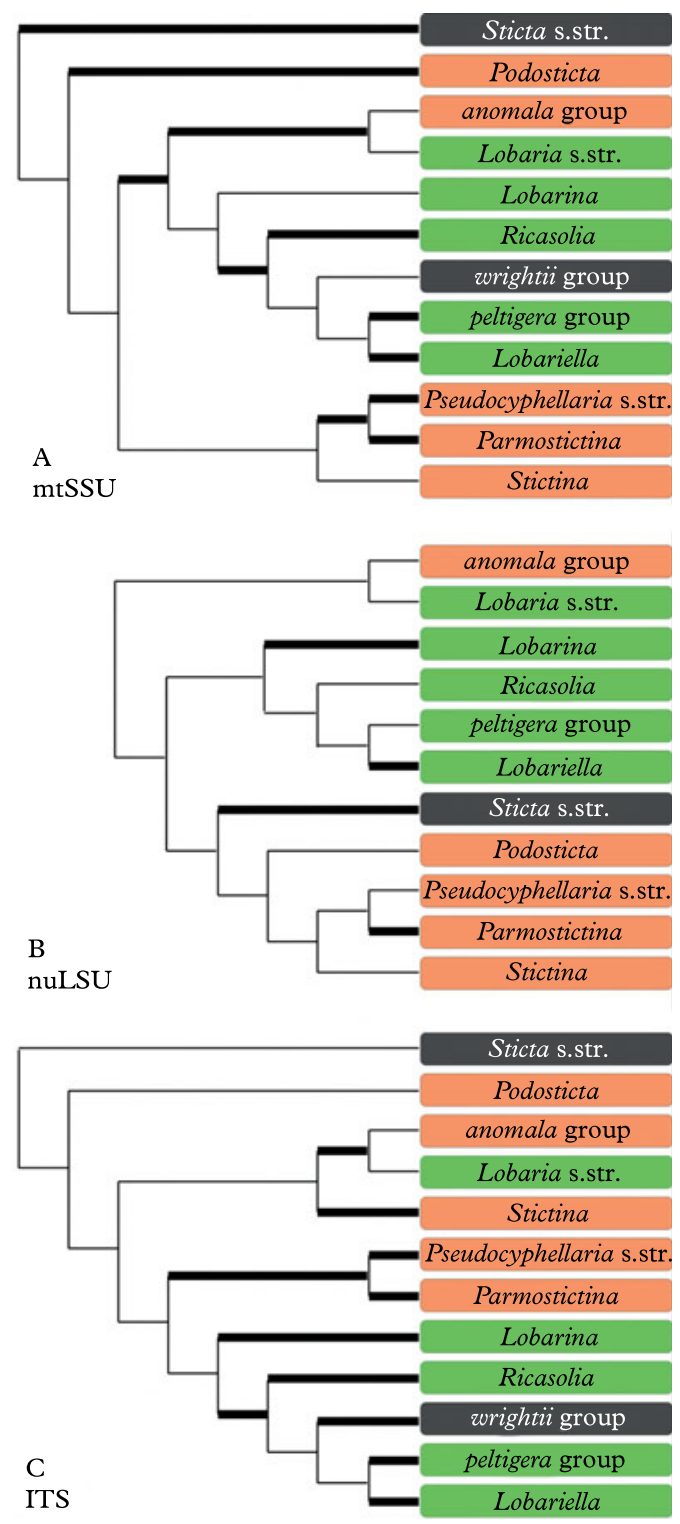

FIG. 2. Alternative clade topologies found in the individual $\mathrm{mtSSU}$, nuLSU, and ITS gene trees. Thick lines indicate clades with bootstrap support $70 \%$ or higher. In colour online.

cyphellaria s. lat., and Sticta s. lat. to be polyphyletic and splitting into several individual clades, the results of our study would at first glance indicate that all three genera could be maintained and only a few species would have to be transferred from Pseudocyphellaria
( $P$. anomala group) and Sticta ( $S$. wrightii group) into Lobaria. However, a closer look demonstrates that this would not be the appropriate solution. The retention of names for convenience does not have a scientific bearing, and neither does it have a rationale 

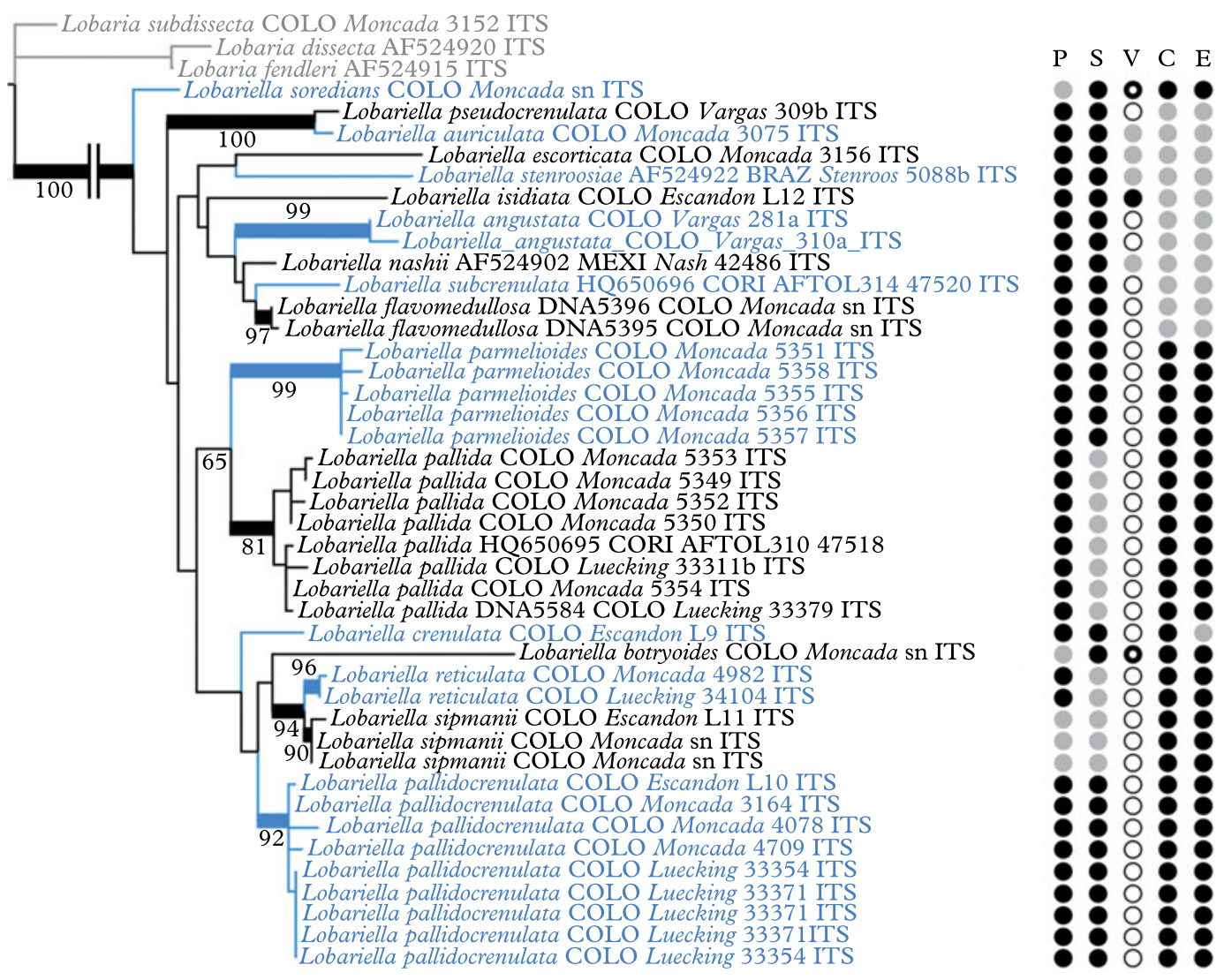

FIG. 3. Molecular ITS tree of the genus Lobariella, with the Lobaria peltigera group as outgroup, reconstructed by means of a maximum likelihood approach in RAxML. Supported branches are indicated by thick lines and bootstrap support values are given. Species-level clades are highlighted. Characters are indicated as follows: $\mathrm{P}=$ photobiont (black $=$ green, grey $=$ blue-green), $\mathrm{S}=$ surface $($ black $=$ pseudocyphellae, grey = maculae), $\mathrm{V}=$ reproductive mode $($ white $=$ apothecia, grey $=$ flattened isidia or phyllidia, black = cylindrical isidia, black ring $=$ soredia), $\mathrm{C}=$ chemistry $($ black $=$ chemosyndrome $\mathrm{A}$, grey = chemosyndrome $\mathrm{B}), \mathrm{E}=$ ecology $($ black $=$ páramo, grey = montane forest). In colour online.

in this case, since the reason to separate three large genera was the absence (Lobaria) or presence of pseudocyphellae (Pseudocyphellaria) or cyphellae (Sticta). The strong support for Lobaria s. lat. including species with pseudocyphellae on the lower side (Pseudocyphellaria anomala group) and on the upper side (Lobariella), and cyphellae-like pores (Sticta wrightii group) on the underside, as well as a complete lack thereof in all other species of the clade, makes this traditional distinction obsolete, since it would then recognize one genus (Lobaria) that encompasses the entire range of variation found in the family. Thus, maintaining the three large clades at the genus level would be a mere attempt to maintain historical nomenclature, but would contribute little to defining natural genus-level taxa and to our understanding of their evolution. Other evidence suggesting that the three large genera should be split up into smaller entities is the lack of support for the Pseudocyphellaria s. lat. clade and the inconsistent placement of the smaller clades in the individual gene trees, which is consistent with earlier studies where this genus was 
split into several clades (Miądlikowska et al. 2002; Högnabba et al. 2009).

Whereas Sticta s. str. is rather homogeneous, both phylogenetically and in its principal morphological and chemical characters (mostly uniform lower tomentum, mostly no substances or rarely unidentified pigments), splitting Lobaria s. lat. and Pseudocyphellaria s. lat. would result in more natural entities with distinct morphodemes and chemosyndromes, even if some variation is still maintained in such smaller genera (Table 2). Thus, Lobaria s. str. is typically characterized by faveolate thalli with a lower tomentum forming veins immersed between the bulges formed of the faveolate surface, short, broadly fusiform ascospores, and a diverse chemistry of depsidones (stictic and norstictic acid and satellite substances), didepsides (tenuiorin), tridepsides (gyrophoric acid and satellite substances), and triterpenes such as retigeric acids A and B (Yoshimura 1971; Culberson et al. 1977; Schumm 2003; Yamamoto et al. 2005; Elix \& Tønsberg 2006; Galloway 2007; Cornejo \& Scheidegger 2010; Sato et al. 2011). The immediate sister clade, the Pseudocyphellaria anomala group, is recognized here at the genus level; the two species closely resemble Lobaria s. str. in morphology and chemistry but have distinct pseudocyphellae on the lower surface and produce hopane terpenes in addition to stictic acid and satellite substances (Kondratyuk \& Galloway 1995; Ryan \& Galloway 2002).

The Lobaria scrobiculata group (Lobarina) is similar to Lobaria s. str. in lobe configuration and medullary chemistry, producing stictic acid and satellite substances (but also the didepsides meta- and para-scrobiculin; Culberson et al. 1977; Goffinet \& Goward 1998; Schumm 2003; Elix \& Tønsberg 2006). However, it has a much denser lower tomentum leaving white, rounded areas that do not correspond to the bulges formed of the faveolate thallus. Another difference is the presence of usnic acid in the cortex, a substance otherwise unknown in the family (Culberson et al. 1977; Yoshimura 1998a). Furthermore, the ascospores are narrowly fusiform to acicular and much longer (Schumm 2003). The chemistry of meta- and para- scrobiculin and the long ascospores are, with the exception of L. virens, shared with the L. amplissima group (Ricasolia; Culberson et al. 1977; Schumm 2003; Elix \& Tønsberg 2006), which has a plane lobe surface and a uniform lower tomentum not forming veins or holes, and at least some species produce atranorin in the cortex, whereas medullary substances also include gyrophoric acid and associated metabolites (Culberson et al. 1977; Yoshimura 1998a, b, 2002). A gyrophoric acid medullary chemistry is found in the L. peltigera and L. crenulata groups (Lobariella), which are otherwise distinguished by the prominent, dark veins formed of the lower tomentum in the L. peltigera group, and the distinct pseudocyphellae or maculae formed on the upper surface in the L. crenulata group (Lobariella); the latter also has a pale lower tomentum composed of hyphae with rounded cells. The importance of medullary chemistry for predicting phylogenetic relationships is seen in the fact that these three groups form a strongly supported clade, which also includes the $S$. wrightii group, in which most species produce gyrophoric acid (Culberson et al. 1977; Chen 1993; Chen et al. 1994; Awasthi 2007).

The Sticta wrightii group is similar to Lobariella in the nature of the lower tomentum, but lacks pseudocyphellae on the upper side and instead has cyphellae-like pores on the lower side. However, these are different in morphology and anatomy from the cyphellae found in Sticta s. str. (see below). This group was already recognized in previous studies (Tønsberg \& Goward 2001; Takahashi et al. 2006; Högnabba et al. 2009) as not belonging in Sticta s. str. but this was not discussed further in detail, although Högnabba et al. (2009) found similar support for a relationship with the two aforementioned Lobaria s. lat. clades. Here, for the first time, we found not only a well-supported sister group relationship with the Lobaria peltigera and $L$. crenulata groups, but also a supported relationship with the L. amplissima group, a sister to these clades. Thus, the Sticta wrightii group is firmly nested within Lobaria s. lat., and we introduce below the new genus Dendriscosticta for this group, with five new 
TABLE 2. Principal characteristics of typical representatives of the subclades of Lobaria s. lat., Pseudocyphellaria s. lat., and Sticta s. lat.

\begin{tabular}{|c|c|c|c|c|c|}
\hline Clade/Group & Available genus name & Cyphellae / Pseudocyphellae & Lower tomentum & Surface structure & Secondary chemistry \\
\hline \multicolumn{6}{|l|}{ Lobaria } \\
\hline Lobaria s. str. & Lobaria & - & dark veins (immersed) & faveolate & (nor)stictic acid aggr. \\
\hline $\begin{array}{l}\text { Pseudocyphellaria } \\
\text { anomala group }\end{array}$ & [none] & pseudocyphellae (lower side) & dark veins (immersed) & faveolate & (nor)stictic acid aggr. \\
\hline $\begin{array}{l}\text { Lobaria } \\
\quad \text { scrobiculata group }\end{array}$ & Lobarina & - & dark, with wholes & scrobiculate & $\begin{array}{l}\text { usnic acid, } \\
\text { (nor)stictic acid aggr. }\end{array}$ \\
\hline $\begin{array}{l}\text { Lobaria } \\
\quad \text { quercizans group }\end{array}$ & $\begin{array}{c}\text { Ricasolia } \\
(=\text { Dendriscocaulon })\end{array}$ & - & dark, uniform & plane & $\begin{array}{l}\text { atranorin, } \\
\text { gyrophoric acid agg. }\end{array}$ \\
\hline $\begin{array}{l}\text { Sticta } \\
\quad \text { wrightii group }\end{array}$ & [none] & cyphelloid pores (lower side) & pale, uniform & plane & gyrophoric acid agg. \\
\hline $\begin{array}{l}\text { Lobaria } \\
\quad \text { peltigera group }\end{array}$ & [none] & - & dark veins (prominent) & plane & gyrophoric acid agg. \\
\hline $\begin{array}{l}\text { Lobaria } \\
\quad \text { crenulata group }\end{array}$ & $\begin{array}{l}\text { Lobariella } \\
(\equiv \text { Durietzia })\end{array}$ & pseudocyphellae (upper side) & pale, uniform & plane & gyrophoric acid agg. \\
\hline \multicolumn{6}{|l|}{ Sticta } \\
\hline Sticta s. str. & Sticta & cyphellae (lower side) & pale to dark (uniform) & $\begin{array}{l}\text { plane to } \\
\text { faveolate }\end{array}$ & $\begin{array}{l}\text { nil } \\
\text { white to yellow medulla }\end{array}$ \\
\hline \multicolumn{6}{|l|}{ Pseudocyphellaria } \\
\hline $\begin{array}{l}\text { Pseudocyphellaria } \\
\text { endochrysea group }\end{array}$ & Podostictina & pseudocyphellae (lower side) & dark, uniform & plane & $\begin{array}{l}\text { stictane triterpenoids, } \\
\text { yellow medulla }\end{array}$ \\
\hline Pseudocyphellaria s. str. & $\begin{aligned} & \text { Crocodia } \\
(= & \text { Parmosticta })\end{aligned}$ & pseudocyphellae (lower side) & dark, uniform & plane & $\begin{array}{l}\text { fernene triterpenoids, } \\
\text { yellow medulla }\end{array}$ \\
\hline P. hirsuta group & Parmostictina & pseudocyphellae (lower side) & dark, uniform & plane & $\begin{array}{c}\text { nil, } \\
\text { white medulla }\end{array}$ \\
\hline P. crocata group & Pseudocyphellaria & pseudocyphellae (lower side) & dark, uniform & $\begin{array}{c}\text { plane to } \\
\text { scrobiculate }\end{array}$ & $\begin{array}{l}\text { hopane triterpenoids, } \\
\text { white medulla }\end{array}$ \\
\hline
\end{tabular}


combinations. The new genus can be divided into the Eastern Hemisphere $S$. nylanderiana clade, including species with a gyrophoric acid medullary chemistry (Chen 1993; Chen et al. 1994), and the mostly Western Hemisphere $S$. wrightii clade, including species lacking medullary substances (Tønsberg \& Goward 2001). One could argue that these two clades deserve formal subgeneric status.

The four clades that can be distinguished within Pseudocyphellaria s. lat., in addition to the $P$. anomala group, are largely differentiated by their medullary chemistry, but also have some morphological characteristics (Galloway et al. 1983; Galloway 1988, 1992, 1994, 2007; Wilkins 1993; Kondratyuk \& Galloway 1995). The P. aurata group has a yellow medulla from pulvinic acid derivates, together with fernene triterpenoides, whereas the closely related $P$. hirsuta group has no medullary substances but usually a tomentose upper surface. Both groups have more or less stipitate apothecia with thalline margin, and they are phylogenetically closely related. The $P$. endochrysa group also has a yellow medulla, but differs from the $P$. aurata group in producing stictane triterpenoids and is also genetically more distant. The latter seems to include very few species, whereas the $P$. crocata group, which is characterized by a mostly white medulla and hopane triterpenoids, is the largest group. Both the $P$. crocata and $P$. endochrysa groups have sessile apothecia with a proper excipulum lacking photobiont cells.

For most of the clades suggested here to form well-delimited genera, names already exist that can be used at the genus level, such as Lobarina for the Lobaria scrobiculata group (Yoshimura 1998a; Högnabba et al. 2009) and Ricasolia for the Lobaria amplissima group. New names are required for the Pseudocyphellaria anomala group and for the Lobaria peltigera group. The first is named Anomalobaria below, whereas for the second, which is most speciose in the Neotropics, we introduce the new genus Yoshimuriella, with eight new combinations, honouring the work of Isao Yoshimura with regard to our knowledge of Lobaria s. lat. For the clades within Pseudocyphellaria s. lat., the following names can be used if future workers decide to accept these clades at genus level: Crocodia Link (Link 1833; see Jørgensen \& Galloway 2011; J. A. Elix \& D. J. Galloway, unpublished data) for the $P$. aurata group [type: Crocodia aurata (Ach.) Link]; Podostictina Clem. (Clements 1909) for the P. endochrysa group [type: Podostictina endochrysoides (Müll. Arg.) Clem. = Pseudocyphellaria compar (Nyl.) H. Magn.]; Parmostictina Nyl. (Nylander 1875) for the P. hirstuta group [type: Sticta hirsuta Nyl. $\equiv$ Pseudocyphellaria hirsuta (Mont.) Malme]; and Pseudocyphellaria Vain. (Vainio 1890; see Jørgensen \& Galloway 2011) for the $P$. crocata group [type: $P$. crocata (L.) Vain.].

The application of the names Crocodia and Pseudocyphellaria depends on whether a recent proposal to keep the latter with a conserved type by Jørgensen \& Galloway (2011) is eventually accepted. Pseudocyphellaria is already a conserved name (Galloway \& Laundon 1988) and currently listed with $P$. aurata as the type. However, Jørgensen \& Galloway (2011) rightfully argued that the $P$. aurata group contains only a small number of species, whereas the bulk of species currently classified as Pseudocyphellaria s. lat. belong to the $P$. crocata group. We agree that, in order to avoid a large number of name changes, conservation of Pseudocyphellaria with $P$. crocata as type would therefore be the preferred solution, then adopting the name Crocodia for the $P$. aurata group (Jørgensen \& Galloway 2011; J. A. Elix \& D. J. Galloway, unpublished data).

The richness of species of Lobariella, as indicated by our expanded ITS analysis, was entirely unexpected. Although we had already described a new species with unique morphology, L. sipmanii (Lumbsch et al. 2011), and two further putative new species awaited description (Moncada et al. 2012a), our first estimate of the total species number for this genus was not more than ten taxa. Yet even with the limited sampling, focusing on Andean montane forests and páramos, we can already distinguish 26 species, supported by either molecular or morphological data or a combination of both, even if some species are known from few or single collections 
only. These 'singletons' are either phylogenetically distinct or feature unique characters: L. ecorticata (unique kind of phyllidia with ecorticate underside, confirmed by ITS data), L. papillifera (unique kind of isidia with papillate surface), L. peltata (only species with peltate phyllidia and only one of two species with lecanoric acid as major medullary substance), L. pseudocrenulata (phylogenetically and chemically distinct), and $L$. spathulifera (with a unique combination of morphological and chemical features).

These results underline the necessity to study even supposedly well-known foliose macrolichens in detail, rather than labelling them when collecting in the field with the aid of only a hand-lens. An even more dramatic increase in species that are supported by molecular ITS data but that can also be recognized morphologically has been found in the genus Sticta, with so far nearly 150 species distinguished in Colombia and taxa such as $S$. fuliginosa divided into more than ten different, partially unrelated species (Moncada \& Lücking 2012; Moncada et al. $2012 b$; Suárez \& Lücking 2013). Surprisingly, this 'hidden' diversity is not cryptic, since species of Lobariella are distinguished by a combination of morphological and chemical characters, albeit sometimes the differences are rather subtle, as for example in $L$. crenulata versus $L$. parmelioides, or $L$. reticulata versus $L$. pallida (see below).

Our findings parallel those found in other groups of related and unrelated lichens, such as the Parmeliaceae (Crespo et al. 2002; Divakar et al. 2005; Argüello et al. 2007; Crespo \& Pérez-Ortega 2009; Crespo \& Lumbsch 2010), and demonstrate that the concept of variation applied to lichenized fungi has to be reconsidered. Before the advent of molecular methods, infraspecific variation was 'defined' by giving a set of individuals the same species name, which is a subjective approach prone to circular conclusions. Molecular phylogeny provides a means to delimit species independent of their morphological characters and, therefore, morphological variation can be objectively assessed. The variation of shapes of flattened isidia and phyllidia found in $\mathrm{Lo}-$ bariella provides an excellent example. Yoshimura (1984: fig. 2) and Yoshimura \& Arvidsson (1994) assumed these to belong to a single species, L. subexornata. The molecular data, however, show that the different kinds of isidia and phyllidia represent separate, in part only distantly related, specieslevel lineages. In general, for the species of Lobariella represented by several samples in the phylogenetic analysis, such as L. pallida, L. pallidocrenulata and L. parmelioides, the morphological and chemical variation was found to be very narrow.

Similar findings are also expected for the large genus Pseudocyphellaria. In our study, we found that sequences identified as Pseudocyphellaria crocata and $P$. perpetua deposited in GenBank represent several distinct, partly unrelated species. We included six sequences labelled $P$. crocata in our combined analysis to show their placement on separate clades. Based on our results, we suspect that several sequences labelled $P$. crocata in GenBank (EU558755, EU558756, EU558757, EU558758, EU558834, EU558839, EU558840, EU558841) represent $P$. lechleri, whereas two further samples from the Paleotropics, together with a sequence labelled $P$. intricata not included in the combined analysis (EU558751, EU558752, EU558780, EU558833, EU558834, EU558848), are phylogenetically distinct from neotropical specimens. Since $P$. crocata has been described from the Palaeotropics (India), it is likely that the neotropical material represents separate, undescribed species. Our experience with $P$. crocata in the Neotropics suggests that at least two distinct taxa are present: one with mostly marginal soralia (resembling $P$. perpetua but with a white medulla) and the other with predominantly laminal soralia. We have not revised any voucher material of the $P$. crocata sequences in Genbank, and therefore cannot state at present whether and which of these correspond to the different morphodemes, but it appears that concepts of the name $P$. crocata representing several species (Magnusson 1940; Galloway 1988, 1992, 1994; Galloway \& Arvidsson 1990; Miądlikowska et al. 2002) are correct. 
We also found that nuLSU sequences of Pseudocyphellaria rainieriensis (AF401963) and P. scabrosa (EU558774) had numerous apparent reading errors, evident from comparison with all other sequences in highly conserved regions. Initial analysis placed these sequences in odd relationships, which would explain why $P$. rainieriensis clustered with Lobaria s. lat. in the analysis of Högnabba et al. (2009). ITS data placed the same specimens within Pseudocyphellaria s. lat. in our initial analyses, but the ITS sequence of $P$. rainieriensis (AF401968) is also of limited quality and therefore we excluded the species from this study. We further excluded Lobaria hallii, since the mtSSU sequence (AY424248) clustered within Lobaria s. lat., whereas the nuLSU sequence (AY424204) came out close to Pseudocyphellaria berberina.

\section{Taxonomic Treatment}

\section{Anomalobaria B. Moncada \& Lücking gen. nov.}

\section{MycoBank No.: MB801853}

Differing from Lobaria s. str. in the presence of pseudocyphellae on the lobe underside.

Type species: Anomalobaria anomala (Brodo \& Ahti) B. Moncada \& Lücking.

Thallus macrofoliose, growing epiphytically or very rarely on mossy rocks or logs, loosely to very loosely attached, often between bryophytes and other lichens; photobiont cyanobacterial (Nostoc). Individual lobes with irregular to nearly rounded apices and irregular to crenate margins, irregularly branched, forming irregular thallus rosettes. Upper surface olive-brown to red-brown when hydrated, brownish grey when dry and becoming yellowish grey to yellowish brown in the herbarium, foveolate to distinctly scrobiculate; pseudocyphellae absent. Isidia absent but brown-black isidia-like structures developing into soredia present in an undescribed species from California. Soredia often present, white, maculate to linear, forming on the ridges and along the margins. Lower surface pale to mid grey-brown or yellowish brown, with a short, dense, fuzzy-arachnoid tomentum; pseudocyphellae present, abundant, white, strongly protruding, without discernible margin, surface farinose-granular, resembling soralia. Medulla white. Apothecia cup-shaped, biatorine. Ascospores broadly fusiform, septate, hyaline.

Pycnidia immersed, with black ostiole. Conidia bifusiform.

Secondary chemistry. Stictic acid and satellite substances, hopane terpenes (7ß-acetoxyhopane-22-ol and hopane-15 $\alpha, 22$-diol in $A$. anthraspis; Kondratyuk \& Galloway 1995).

Notes. This genus is introduced here for the Pseudocyphellaria anomala group, which is sister to Lobaria s. str. but differs in the pseudocyphellae formed on the lobe underside. It shares the stictic acid medullary chemistry with most species of Lobaria s. str. (Culberson et al. 1977; Kondratyuk \& Galloway 1995; Elix \& Tønsberg 2006). The genus name is a combination of Lobaria and the epithet of the type species, anomala. Thus far, two species are known, but material from California producing coralloid, isidialike structures (e.g. Richards $\mathcal{E}$ Drouet 1314 in F) might represent a further taxon. A rare sorediate form otherwise similar to $A$. anthraspis has been reported from Canada (Goward et al. 1994).

\section{Anomalobaria anomala (Brodo \& Ahti) B. Moncada \& Lücking comb. nov.}

\author{
MycoBank No.: MB801856
}

Pseudocyphellaria anomala Brodo \& Ahti in Ahti et al., Mycotaxon 28: 95 (1987).- -Sticta limbata var. anomala G. Merr., Lich. Exs. 1: no. 25 (1909) [nom. nud.].Pseudocyphellaria anomala G. Merr. ex H. Magn., Acta Horti Gothoburgensis 13: 248 (1939) [nom. inval.]; type: USA, Washington, Foster s.n. (CANL-holotype, not seen; H-isotype!; Merrill, Lich. Exs. 1, no. 25).

\section{Anomalobaria anthraspis (Ach.) B. Moncada \& Lücking comb. nov.}

\section{MycoBank No.: MB801857}

Sticta anthraspis Ach., Methodus Lichenum: 280 (1803),Cyanisticta anthraspis (Ach.) Gyeln., Lichenotheca parva, Fasc. 1, No. 8 (1937).-Pseudocyphellaria anthraspis (Ach.) H. Magn., Acta Horti Gothoburgensis 13: 248 (1939); type: North America (unknown locality), Menzies s.n. (E-lectotype, not seen; BM, LINN-SM 1705.14 pr.p., LINN-SM 1705.15-isolectotypes!; Galloway 1995: 118). 


\section{Dendriscosticta B. Moncada \& Lücking gen. nov.}

\section{MycoBank No.: MB801854}

Differing from Sticta s. str. in the morphology of the cyphelloid pores on the underside and the often isidiatephyllidiate chloromorphs.

Type species: Dendriscosticta wrightii (Tuck.) B. Moncada \& Lücking.

Thallus macrofoliose, growing epiphytically or very rarely on mossy rocks or logs, loosely to very loosely attached, often between bryophytes and other lichens; primary photobiont green (Dictyochloropsis), but dendriscocauloid cyanomorph with cyanobacterial photobiont (Nostoc) often present. Individual lobes with irregular to rounded apices and irregular to sinuose margins, irregularly branched, forming irregular to rounded thallus rosettes. Upper surface pale grey-green when hydrated, whitish grey when dry and becoming pale yellowish grey in the herbarium, smooth but especially when young often scabrose-tomentose; pseudocyphellae absent. Isidia sometimes present, sparse, globose to cylindrical. Soredia absent. Lower surface pale brown, glabrous to thinly tomentose; cyphellae-like pores present, abundant, white, flat, with differentiated margin but not smooth and regular and overarching as in Sticta s. str. Medulla white. Apothecia cupshaped, lecanorine. Ascospores narrowly fusiform to acicular, septate, hyaline.

Pycnidia immersed, with black ostiole. Conidia bifusiform.

Secondary chemistry. Pseudocyphellarin A, gyrophoric acid, and methyl-gyrophorate in most Eastern Hemisphere species (Chen 1993; Chen et al. 1994; Awasthi 2007) and lacking substances in Western Hemisphere species (Tønsberg \& Goward 2001).

Notes. This genus is introduced here for the Sticta wrightii group, a well-supported, more or less Northern Hemisphere clade nested within the Lobaria s. lat. clade and sister to Yoshimuriella plus Lobariella, but characterized by the formation of cyphellaelike pores on the underside. These are, however, morphologically and anatomically different from those in Sticta s. str., being intermediate between genuine cyphellae and pseudocyphellae, in having a distinct but not smooth and overarching margin, and lacking the distinct basal membrane characteristic of cyphellae. We introduce the term cyphelloids for these pores (not to be confused with the cyphelloid basidiocarps of Cyphella Fr. and other basidiomycetes). The species of this genus frequently produce Dendriscocaulonlike cyanomorphs as in the closely related Lobaria amplissima group (Ricasolia), but such cyanomorphs are also found in some species of Sticta s. str. (Tønsberg \& Goward 2001; Takahashi et al. 2006). Dendriscosticta has a chemistry similar to the related $\mathrm{Lo}$ bariella and Yoshimuriella (atranorin reported by Awasthi 2007 is actually pseudocyphellarin A), emphasizing the importance of secondary chemistry for systematic relationships. However, the mostly western species (although D. wrightii is known throughout the Northern Hemisphere) apparently lack lichen substances and in this feature correspond with Sticta s. str. It is therefore not surprising that the true relationships of this group were not recognized before.

The division of this group into the Eastern Hemisphere D. platyphylla clade and the mostly Western Hemisphere D. wrightii clade, with a different medullary chemistry, has to be studied further. Sticta wrightii appears to be a collective species. Analysis of nine available ITS sequences in GenBank, including dendriscocauloid cyanomorphs, suggests that up to five species can be distinguished, with one clade known from China and the other four from Japan, China, and Cameroon (Fig. 4).

\section{Dendriscosticta platyphylla (Trevis.) B. Moncada \& Lücking comb. nov.}

\section{MycoBank No.: MB801858}

Lobaria platyphylla Trevis., Lichenoth. Veneta: nos. 75, 76 (1869) [nom. nov.].-Sticta platyphylla Nyl., Syn. Meth. Lich. 1(2): 357 (1860) [nom. illeg., non S. platyphylla A. Massal.].-S. nylanderiana Zahlbr., Cat. Lich. Univ. 3: 356 (1925) [nom. nov.]; type: Nepal, Hooker f. E Thomson 1963 (H-NYL 37652-lectotype!).

Notes. The original epithet platyphylla instead of nylanderiana is to be taken up in 


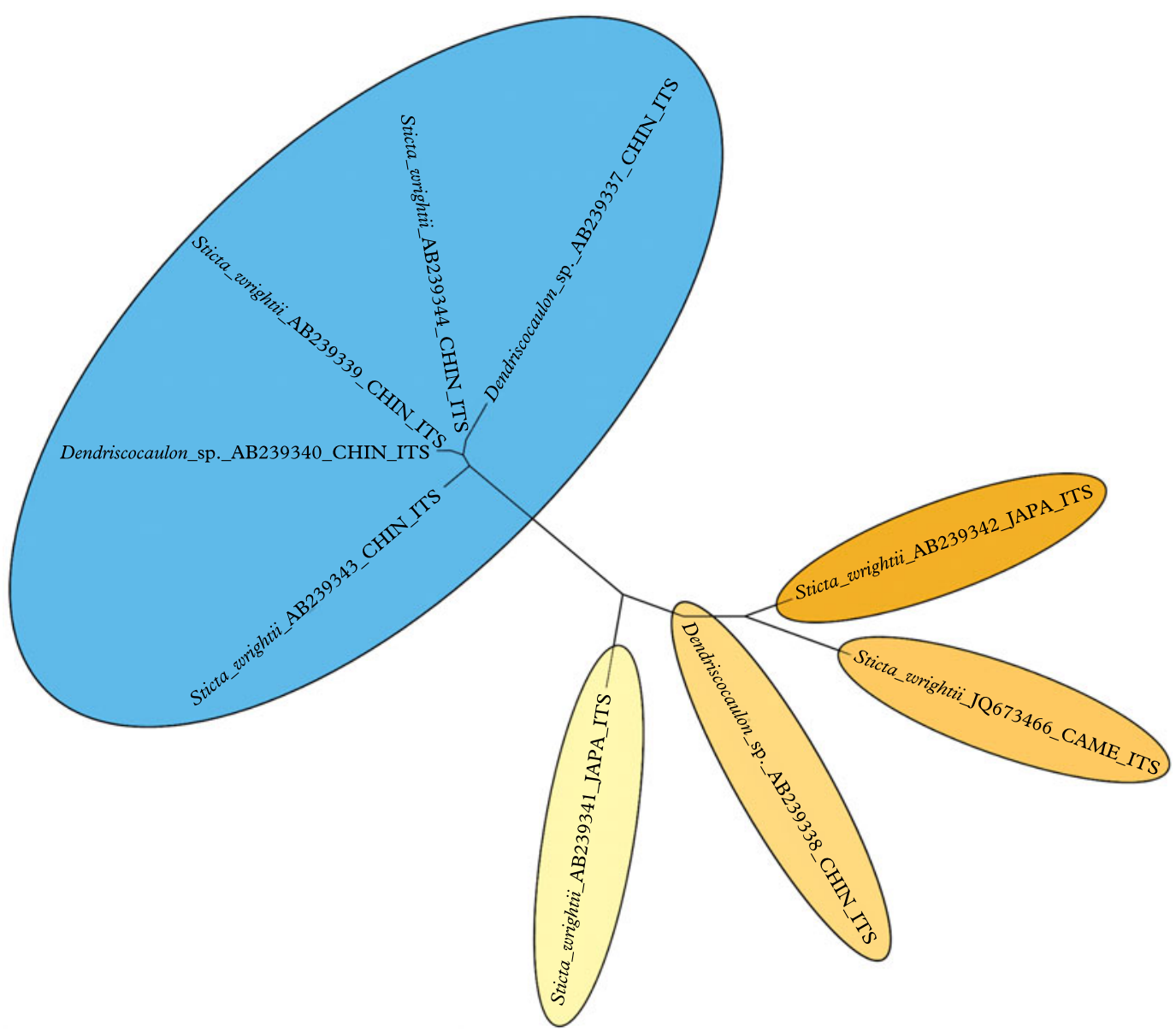

FIG. 4. Molecular ITS tree of the Sticta wrightii aggregate, suggesting that this name contains more than one species. In colour online.

a new genus combination, based on the replacement name Lobaria platyphylla Trevis., since the use of this epithet is only blocked in the genus Sticta, with S. platyphylla A. Massal. as the earlier homonym.

\section{Dendriscosticta platyphylloides (Nyl.) B. Moncada \& Lücking comb. nov.}

\section{MycoBank No.: MB801859}

Sticta platyphylloides Nyl., Bull. Soc. Bot. Fr. 34: 22 (1887); type: China (Yunnan), Delavay 107 (H-NYL 33665-lectotype!).

\section{Dendriscosticta oroborealis (Goward \& Tønsberg) B. Moncada \& Lücking comb. nov.}

MycoBank No.: MB801860

Sticta oroborealis Goward \& Tønsberg in Tønsberg \& Goward, Bryologist 104: 19 (2001); type: Canada, British Columbia, Tønsberg \& Goward 20665 (BG-holotype, not seen; CANL—isotype, not seen).

\section{Dendriscosticta praetextata (Räsänen) B. Moncada \& Lücking comb. nov.}

MycoBank No.: 801861

Sticta platyphylla var. praetextata Räsänen, Arch. Soc. Zool. Bot. Fenn. 6: 84 (1952).—S. praetextata (Räsänen) 
D. D. Awasthi in Joshi \& Awasthi, Biol. Mem. 7: 185 (1982); type: India, Awasthi $\mathcal{E}$ Awasthi 109 (H-holotype!; LWG-Awasthi-isotype, not seen).

\section{Dendriscosticta wrightii (Tuck.) B. Moncada \& Lücking comb. nov.}

MycoBank No.: MB801862

Sticta wrightii Tuck., Amer. F. Sci. Arts, Ser. 2, 28: 204 (1859); type: Japan, Wright s. n. (FH-holotype!).

\section{Yoshimuriella B. Moncada \& Lücking gen. nov.}

\section{MycoBank No.: MB801855}

Differing from Lobaria s. str. in the smooth, not faveolate, upper surface, the lower tomentum organized in more or less distinct veins, and the gyrophoric acid chemistry.

Type species: Yoshimuriella fendleri (Tuck. \& Mont.) B. Moncada \& Lücking.

Thallus macrofoliose, growing epiphytically or very rarely on mossy rocks or logs, loosely to very loosely attached, often between bryophytes and other lichens; photobiont green (Dictyochloropsis). Individual lobes with rounded apices and sinuose margins, irregularly to dichotomously branched, forming rounded to irregular thallus rosettes. Upper surface bright green when hydrated, pale grey when dry and becoming yellowish grey to pale yellowish brown in the herbarium, smooth or rarely canaliculate; pseudocyphellae absent. Isidia or more frequently phyllidia and lobules often present, usually marginal. Soredia absent. Lower surface white, short, dense, dark brown tomentum developed in more or less vein-like pattern; pseudocyphellae absent. Medulla white. Apothecia cup-shaped, lecanorine, usually with distinctly lobed thallus margins. Ascospores narrowly fusiform to acicular, septate, hyaline.

Pycnidia immersed, with black ostiole. Conidia oblong.

Secondary chemistry. Pseudocyphellarin A, gyrophoric and congyrophoric acids.

Notes. This genus is introduced here for the Lobaria peltigera group, a phylogenetically and morphologically well-supported, predominantly neotropical clade (with a few species in other regions) and the predominant group of Lobaria s. lat. in the Neotropics besides Lobariella (Yoshimura 1969,
$1998 a, b)$. In spite of its abundance, no generic name apparently exists for this group. The new genus is dedicated to Isao Yoshimura, who, with his studies, contributed substantially to our knowledge of the Lobariaceae, and particularly the genus Lobaria and its allies. In early treatments of this group, the $\mathrm{K}+$ yellow reaction of the cortex was interpreted as the presence of tannoids (Yoshimura 1969) but it is caused by the didepsid pseudocyphellarin A (Yoshimura $1998 a, b)$.

Since Yoshimura $(1998 a, b)$ named this group the Lobaria peltigera group, it would have been logical to choose L. peltigera (Delise) Vain. as the type species for Yoshimuriella. However, the basionym Sticta peltigera Delise is illegitimate, since Delise (1822) cited Sticta dissecta ("Ach. Lich. Univ. p. 451. Synops. Lich. p. 235") as synonym, deliberately changing the name for this species. Contrary to the entry in Index Fungorum, which cites Delise (1822) as the recombination author of Sticta dissecta, it was Acharius who recombined Lichen dissectus Sw. into Sticta (Acharius 1803: 279) and used this name in the work cited by Delise (Acharius 1810: 451). Therefore, the name Sticta peltigera Delise is automatically typified by the type of Lichen dissectus Sw. and a synonym of the latter, unless proposed for conservation with a different type. Unfortunately there appears to be no other name available for the species known as Lobaria peltigera, which for the time being must remain nameless until a conservation proposal with an appropriate type has been formulated.

\section{Yoshimuriella carassensis (Vain.) B. Moncada \& Lücking comb. nov.}

\section{MycoBank No.: MB801863}

Lobaria carassensis Vain., Acta Soc. Fauna Fl. Fenn. 7: 200 (1890); type: Brazil, Vainio s. n. (TUR-VAIN 10667-holotype!; FH, PC-isotypes!; Vainio, Lich. Bras. Exs. 1257).

\section{Yoshimuriella corrosa (Ach.) B. Moncada \& Lücking comb. nov.}

\section{MycoBank No.: MB801864}

Sticta dissecta var. corrosa Ach., Lichenogr. Universalis: 451 (1810).-Lobaria corrosa (Ach.) Vain., Étud. Lich. Brés.: 200 (1890); type: Peru, Cavanilles s.n. (H-ACH 1532A-holotype!). 


\section{Yoshimuriella deplanata (Nyl.) B. Moncada \& Lücking comb. nov.}

\section{MycoBank No.: MB801880}

Ricasolia subdissecta f. deplanata Nyl., Ann. Sci. Nat., Bot., Sér. 5, 7: 306 (1867) MycoBank No.: 801879.Lobaria deplanata (Nyl.) Yoshim., F. Hattori Bot. Lab. 32: 60 (1969); type: Colombia, Lindig 79 (H-NYL 33416-holotype!; FH-isotype!).

\section{Yoshimuriella dissecta (Sw.) B. Moncada \& Lücking comb. nov.}

\section{MycoBank No.: MB801869}

Lichen dissectus Sw., Prodr.: 147 (1788)._ Lobaria dissecta (Sw.) Räuschel, Acta Soc. Fauna Flora Fenn. 7: 199 (1890); type: Jamaica, Swartz s. n. (H-ACH 1532Bholotype!).

\section{Yoshimuriella fendleri (Tuck. \& Mont.) B. Moncada \& Lücking comb. nov.}

\section{MycoBank No.: MB801865}

Sticta fendleri Tuck. \& Mont., Ann. Sci. Nat., Bot., Sér. 4, 7: 144 (1857).- Lobaria fendleri (Tuck. \& Mont.) Lindau, Mém. Soc. Neuchatel Sci. Nat. 5: 62 (1912); type: Venezuela, Fendler 11 (PC-holotype!).

\section{Yoshimuriella subcorrosa (Nyl.) B. Moncada \& Lücking comb. nov.}

\section{MycoBank No.: MB801867}

Ricasolia subcorrosa Nyl., Flora 52: 314 (1869) [nom. nud.]; Nylander in Fournier, Mexicanas Pl. 1: 4 (1872).-Lobaria subcorrosa (Nyl.) Vain., Philipp. F. Sci. 8: 136 (1913); type: Mexico, Virlet d'Aout 94 (HNYL-holotype, not seen).

\section{Yoshimuriella subdissecta (Nyl.)}

\section{B. Moncada \& Lücking comb. nov.}

\section{MycoBank No.: MB801868}

Ricasolia subdissecta Nyl., Ann. Sci. Nat., Bot. Sér. 4, 11: 214 (1859).-Lobaria subdissecta (Nyl.) Vain., Hedwigia. 38: 124 (1899); type: Bolivia, Weddell s. n. (H-holotype!).

Notes. Yoshimura (1969) suggests a syntype of Ricasolia subdissecta originating from Colombia. However, Nylander (1860) mentions only a collection from Bolivia in the protologue, so this has to be considered the holotype.

\section{Lobariella Yoshim.}

in Nash et al., Lichen Flora of the Greater Sonoran Desert Region 1: 270 (2002).-Durietzia (C. W. Dodge)
Yoshim. in Marcelli \& Ahti, Recollecting Edvard August Vainio: 90 (1998) [nom. illeg., non Durietzia Gyeln.].Lobaria sect. Durietzia C. W. Dodge, Beih. Nova Hedwigia 12: 146 (1964).

Type species: Lobariella crenulata (Hook.) Yoshim.

Notes. This genus is recognized here as a well-supported clade, both phylogenetically and morphologically. Its apparently unique synapomorphy is the presence of distinct maculae and/or pseudocyphellae on the upper surface, which is otherwise smooth to sometimes ridged or scrobiculate in older thallus parts. The lower tomentum is generally pale (rarely dark) and uniform and not organized in veins. The genus is predominantly neotropical, but Lobariella crenulata has also been reported from Hawaii (Yoshimura 1984; Yoshimura \& Arvidsson 1998).

Yoshimura (1984) and Yoshimura \& Arvidsson (1994) provided a thorough treatment of secondary substances occurring in Lobariella, with nine compounds listed (including spot colour after charring and $\mathrm{Rf}$ value in solvent $C$, sorted by $R f$ value): unidentified substance US4 (yellow, 0.73); 4-O-methyl-gyrophoric acid (yellow, 0.46); methyl-gyrophorate (orange-yellow, 0.43); unidentified substance US3 (brownish, 0.42); methyl-lecanorate (orange-yellow, 0.39); gyrophoric acid (yellow, 0.27); lecanoric acid (yellow, 0.24); unidentified substance US1 (orange-red, 0.19); and unidentified substance US2 (brownish, 0-13). Using solvent $\mathrm{C}(170 \mathrm{ml}$ toluene, $30 \mathrm{ml}$ glacial acetic acid), we were able to reproduce these results and confirmed two distinctive chemosyndromes in the genus, dominated by either gyrophoric and lecanoric acid or by unidentified substance US3 (Fig. 5). The latter had unique spot characteristics: immediately after charring, the spot displayed a bright turquoise-green centre with a yellow-grey halo (Fig. 5), but after a few minutes the colour faded and changed to brown. The unidentified substance US4 (named tannoid in Yoshimura 1969 and substance A in Yoshimura 1984) is a cortical substance very similar to atranorin in $\mathrm{Rf}$ value, spot colour after charring, and cortical spot tests ( $\mathrm{K}+$ yellow), but differs in the microcrystal test (Yoshimura 1984; Yoshimura \& Arvidsson 1994). This substance represents pseudocyphellarin A, 


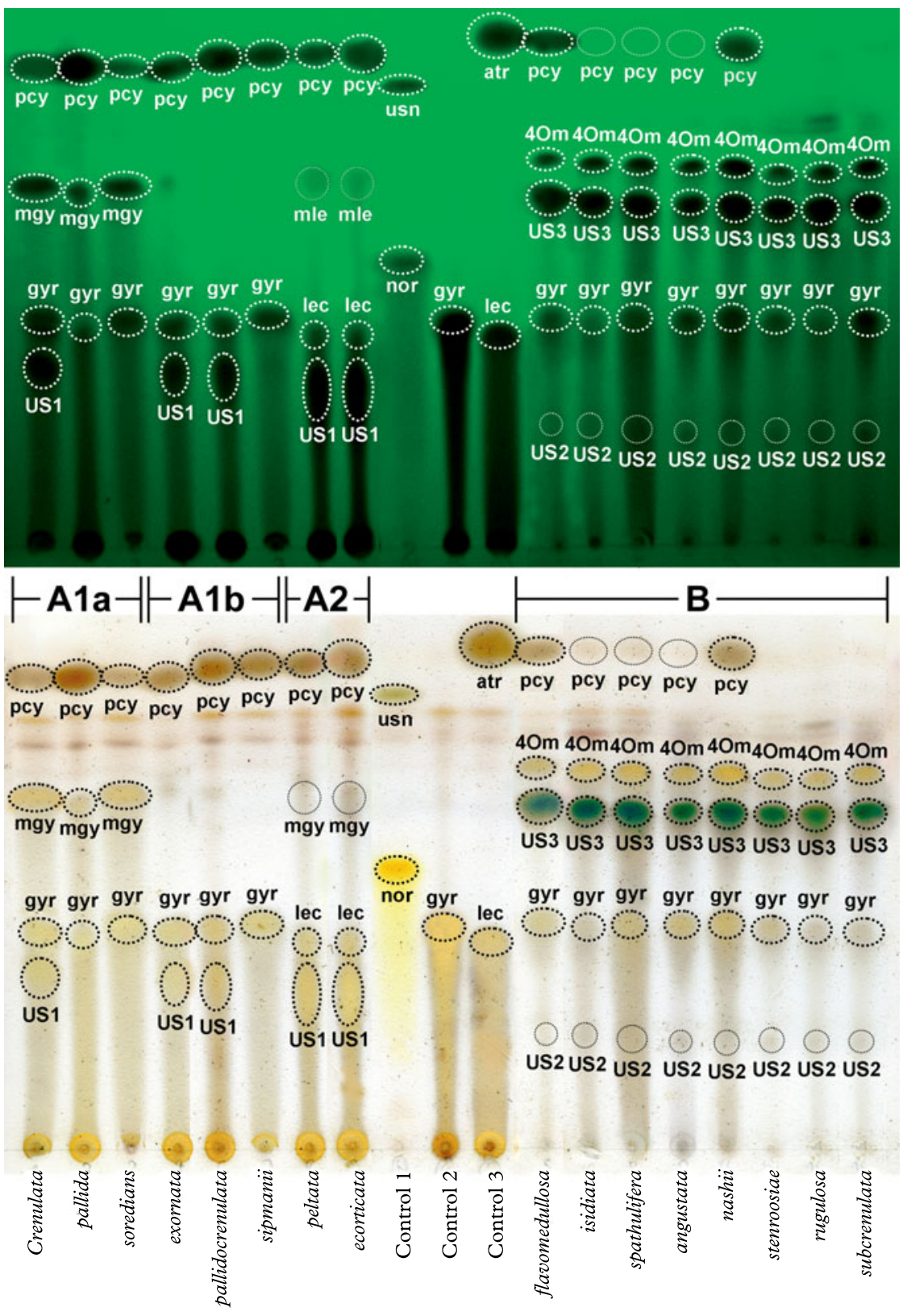

FIG. 5. Exemplar thin-layer chromatography plate of 16 selected species of Lobariella plus three control species, run in solvent C (toluene / glacial acetic acid). Upper portion shows plate before charring under short-wave UV light and lower portion immediately after charring with sulphuric acid (the aeruginous colour of US3 disappears after $c$. $5 \mathrm{~min}$ ). Substances in Lobariella are abbreviated as follows: pcy = pseudocyphellarin A; 4Om $=4-O$-methylgyrophoric acid; US3 = Lobariella unidentified 3; mgy = methyl-gyrophorate; mle = methyl-lecanorate; gyr = gyrophoric acid; lec = lecanoric acid; US1 = Lobariella unidentified 1; US2 = Lobariella unidentified 2. Controls were Usnea angulata (1), Cryptothecia striata (2), and Parmotrema austrosinense (3), with the following additional substance abbreviations: usn $=$ usnic acid; atr $=$ atranorin; nor $=$ norstictic acid. Chemosyndromes are indicated as $\mathrm{A} 1 \mathrm{a}, \mathrm{A} 1 \mathrm{~b}, \mathrm{~A} 2$, and $\mathrm{B}$. In colour online. 
which appears to be a widespread cortical substance in Lobariaceae with a green photobiont, known from several clades. We suspect that the reports of atranorin in this family might at least in part represent pseudocyphellarin A, although Elix \& Tønsberg (2006) reported both substances from $\mathrm{Lo}$ baria hallii. The unidentified substances US1, US2 and US3 are medullary compounds and are here named Lobariella unidentified 1, 2 and 3, the last representing US3 with the bright turquoise-green spot colour after charring in TLC.

Despite their thorough analysis using both TLC and HPLC, and in spite of finding two quite distinct chemical patterns, Yoshimura (1984) and Yoshimura \& Arvidsson (1994) did not consider secondary chemistry to be of any taxonomic value in Lobariella. Instead, the different chemosyndromes were merged within the common and supposedly variable species $L$. crenulata and L. exornata. Our phylogenetic analysis demonstrates that the two distinct chemosyndromes correlate well with major clades and hence clearly cannot be accepted as infraspecific variation; rather, we found that species with similar morphology but different chemistry are not closely related. The two main chemosyndromes differ as follows:

Chemosyndrome A has gyrophoric (A1) or lecanoric acid (A2) and pseudocyphellarin A as regularly major compounds, and methylgyrophorate (A1a, A1b) or methyl-lecanorate (A2) and Lobariella unidentified 1 as occasional major or minor substances. Lobariella unidentified 1 is a major substance in chemosyndrome A2 and occasionally present in chemosyndrome A1. Chemosyndrome A1 might also contain traces of lecanoric acid but these, if present, are masked by gyrophoric acid both in solvent $\mathrm{A}$ and solvent $\mathrm{C}$. The typical medullary spot reaction is $\mathrm{C}+$ pink-red. Chemosyndrome $\mathrm{A} 1$ is found in Lobariella crenulata and L. pallida and its allies, as well as in L. exornata, L. subexornata, and the cyanobacterial species $L$. botryoides, $L$. sipmanii, and L. soredians, whereas chemosyndrome A2 occurs in L. ecorticata and $L$. peltata.
Chemosyndrome $\mathrm{B}$ is characterized by the presence of Lobariella unidentified 3 (major), 4-O-methyl-gyrophoric acid (major), gyrophoric acid (minor, trace or absent), Lobariella unidentified 2 (minor or trace), and pseudocyphellarin A (major, minor, trace, or absent). For unknown reasons, the cortex always reacts $\mathrm{K}+$ yellow, even if pseudocyphellarin A is not detected by TLC. The typical medullary spot reaction is $\mathrm{C}-$ and $\mathrm{K}+$ emerald green (when gyrophoric acid is absent), or C+ sordid salmon-rose or brownish and $\mathrm{K}+$ sordid yellow-green (when gyrophoric acid is present in variable amounts). This chemosyndrome is characteristic of several newly recognized species morphologically similar to $L$. crenulata and $L$. subexornata, such as L. auriculata, L. flavomedullosa, L. stenroosiae, L. pseudocrenulata, L. rugulosa, and L. subcrenulata.

Apart from chemistry and photobiont, the main variation in the genus is found in lobe configuration, presence and arrangement of maculae and pseudocyphellae, the nature of vegetative propagules, apothecial margin morphology, and lower tomentum colour. Important species-specific characters could be found in the shape and colour of the vegetative propagules, representing cylindrical (L. exornata, L. isidiata) or (partially) flattened (L. auriculata, L. corallophora, L. spathulifera, L. subcorallophora, L. subexornata) isidia or dorsiventral phyllidia (L. ecorticata, L. nashii, L. peltata, L. stenroosiae). Also, while the lower tomentum is pale in most taxa, a few species have a characteristically dark lower tomentum (L. auriculata, L. ecorticata, L. peltata, L. subcorallophora). In contrast, the anatomy of thallus and apothecia is rather uniform, and while some quantitative variation exists with regard to internal apothecial measurements and ascospore size, these differences do not seem to be useful in the distinction of species, as long as no quantitative analysis of many samples is available.

The diversity of species found in Lobariella, based on either molecular or morphological and chemical characters, or a combination of both (Table 3), was unexpected. Yet, we have to emphasize that this study is not a 


\begin{tabular}{|c|c|c|c|c|c|c|c|c|c|c|c|c|c|c|c|c|c|c|c|c|c|c|}
\hline Species & PHO & REP & THA & WID & LOB & SUR & MAC & PSE & TOM & APOMAR & ISI & COR & BRA & $\mathrm{COL}$ & DEV & SOR & SHA & $\mathrm{CHE}$ & PIG & COR-K & MED-K & MED- \\
\hline pallida* & green & apot & very & $10-20$ & trun & smo & hyp & - & pale & lob $(7-15)$ & - & - & - & - & - & - & - & A1a & - & yellow & - & p-red \\
\hline reticulata* & green & apot & loose & $5-10$ & irre & smo & reti & - & pale & $\operatorname{cri}(15-30)$ & - & - & - & - & - & - & - & $\mathrm{A} 1 \mathrm{~b}$ & - & yellow & - & p-red \\
\hline pallidocrenulata* & green & apot & very & $10-20$ & trun & smo & irre & irre & pale & lob $(7-15)$ & - & - & - & - & - & - & - & $\mathrm{A} 1 \mathrm{~b}$ & - & yellow & - & p-red \\
\hline parmelioides* & green & apot & loose & $5-10$ & parm & ridg & - & irre & pale & lob $(10-20)$ & - & - & - & - & - & - & - & $\mathrm{A} 1 \mathrm{~b}$ & - & yellow & - & p-red \\
\hline crenulata* & green & apot & loose & $5-10$ & irre & smo & - & irre & pale & $\operatorname{cri}(15-30)$ & - & - & - & - & - & - & - & A1a & - & yellow & - & p-red \\
\hline xornata & green & isid & close & $5-10$ & parm & smo & - & irre & pale & - & cyli & cort & di-ba & conc & lam & - & - & $\mathrm{A} 1 \mathrm{~b}$ & - & $\mathrm{v}$ & - & red \\
\hline corallophora & green & isid & loose & $5-10$ & irre & smo & - & line & pale & - & bas & cort & di-po & apic & pse & - & - & $\mathrm{A} 1 \mathrm{~b}$ & - & ellow & - & p-red \\
\hline subexornata & green & isid & close & $7-15$ & irre & smo & - & irre & pale & - & flat & cort & di-ba & conc & lam & - & - & $\mathrm{A} 1 \mathrm{~b}$ & - & yellow & - & p-red \\
\hline ecorticata* & green & phyl & loose & $5-10$ & irre & smo & - & line & dark & - & dors & ecor & di-po & apic & pse & - & - & $\mathrm{A} 2$ & - & yellow & (yel-brown) & red \\
\hline peltata & green & phyl & loose & $3-7$ & irre & smo & - & irre & dark & - & pelt & cort & irre & conc & lam & - & - & A2 & - & yellow & (yel-brown) & red \\
\hline flavomedullosa* & green & apot & close & $1.5-3$ & parm & unev & - & irre & pale & lob $(7-15)$ & - & - & - & - & - & - & - & B & yellow & yellow & yellow-red & (s-rose) \\
\hline angustata* & green & apot & close & $5-10$ & irre & smo & irre & irre & pale & lob $(7-15)$ & - & - & - & - & - & - & - & B & - & yellow & emer-green & (s-rose) \\
\hline rugulosa & green & apot & close & $3-5$ & parm & rug & - & irre & pale & lob $(7-15)$ & - & - & - & - & - & - & - & B & - & yellow & emer-green & (s-rose) \\
\hline subcrenulata* & green & apot & close & $7-15$ & round & unev & - & irre & pale & lob $(7-15)$ & - & - & - & - & - & - & - & B & - & yellow & emer-green & (s-rose) \\
\hline olivascens & green & apot & asce & $7-15$ & irre & smo & irre & line & pale & lob $(7-15)$ & - & - & - & - & - & - & - & B & - & yellow & emer-green & (s-rose) \\
\hline pseudocrenulata* & green & apot & loose & $5-10$ & parm & smo & irre & irre & pale & lob $(7-15)$ & - & - & - & - & - & - & - & B & - & yellow & emer-green & (s-rose) \\
\hline isidiata* & green & isid & close & $3-6$ & parm & scro & - & line & pale & - & cyli & cort & di-ba & apic & pse & - & - & B & - & & emer-s & (s- \\
\hline subcorallophora & green & isid & loose & $7-15$ & irre & ridg & - & line & dark & - & bas & cort & di-po & apic & pse & - & - & B & - & yellow & emer-green & (s-rose) \\
\hline papillifera & green & isid & close & $5-10$ & parm & ridg & - & line & pale & - & flat & papi & di-ba & conc & pse & - & - & B & - & yellow & emer-green & (s-rose) \\
\hline auriculata* & green & isid & loose & $7-15$ & irre & ridg & - & line & dark & - & flat & cort & di-po & apic & pse & - & - & B & - & yellow & emer-green & (s-rose) \\
\hline spathulifera & green & isid & close & $7-15$ & round & ridg & - & irre & pale & - & flat & cort & di-po & apic & pse & - & - & B & - & yellow & emer-green & (s-rose) \\
\hline stenroosiae* & green & phyl & close & $7-15$ & irre & ridg & - & irre & pale & - & dors & cort & di-ba & conc & lam & - & - & B & - & yellow & emer-green & (s-rose) \\
\hline nashii* & green & phyl & close & $10-20$ & irre & unev & irre & irre & pale & - & dors & cort & di-po & conc & lam & - & - & B & - & yellow & emer-green & (s-rose) \\
\hline sipmanii* $^{*}$ & blue & apot & very & $5-15$ & irre & smo & reti & - & & - & - & - & - & - & - & - & - & A & - & & - & \\
\hline soredians* & blue & sore & asce & $5-8$ & round & unev & reti & reti & pale & - & - & - & - & - & - & mar & lin & Ala & - & ow & - & p-red \\
\hline botryoides* & blue & sore & asce & $5-8$ & round & ridg & reti & reti & pale & - & - & - & - & - & - & lam & dac & Ala & - & yellow & - & p-red \\
\hline
\end{tabular}

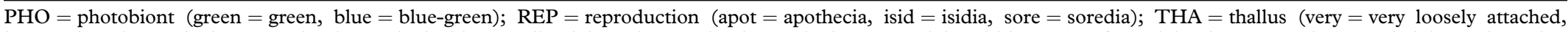

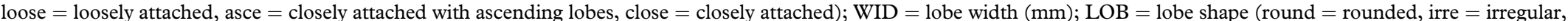

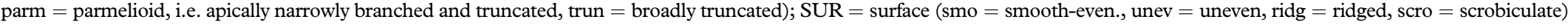

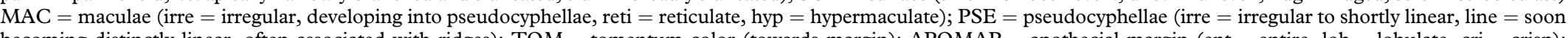

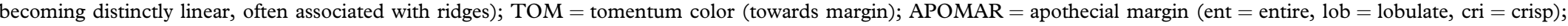

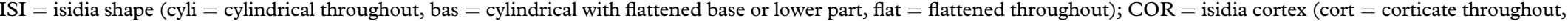

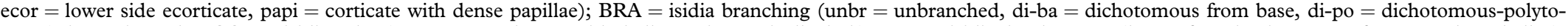

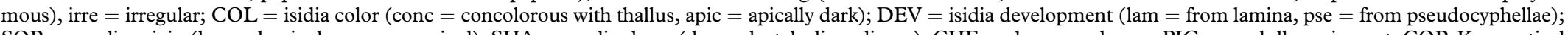

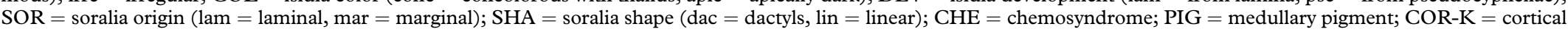

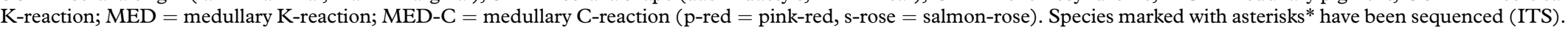


thorough revision of the genus Lobariella, but rather a first attempt at classifying the unexpected genetic, chemical and morphological diversity found in material studied from Costa Rica, Colombia and Brazil. Clearly, the variation described in material reported from throughout the Americas (Yoshimura 1984; Yoshimura \& Arvidsson 1994) and the occurrence of the genus in such remote geographical areas as Hawaii (Yoshimura 1984) suggest additional, unrecognized species to be present. Based on the results from our rather limited sampling, we predict that this genus may contain up to 50 species. It appears that Lobariella provides a good example of the degree to which species richness in foliose macrolichens is being underestimated, as compared with crustose microlichens which are commonly believed to har- bour most of the yet undescribed species (Lücking et al. 2009). Most of the species accepted below are readily recognized by a combination of morphological and chemical features, and only in a few instances, such as $L$. reticulata versus $L$. pallida, $L$. parmelioides versus $L$. crenulata, and $L$. nashii versus $L$. stenroosiae, would we have to label a species as (semi-)cryptic. The phylogenetic analysis, even if lacking backbone support, displays some notable correlations between clades, chemistry, and ecology. Thus, the clade including Lobariella pallida and several other species concentrates the taxa with chemosyndrome $A$, and these are mostly found in the páramo zone. In contrast, most of the species outside this clade have chemosyndrome $B$ and are found in montane to subandine rain and cloud forests.

\section{Key to the species of Lobariella}

1 Photobiont blue-green (Nostoc); secondary chemistry chemosyndrome A1 . . . 2 Photobiont green (Dictyochloropsis); secondary chemistry variable. . . . . . . . 4

2(1) Thallus with apothecia (apothecia with more or less entire margin, lacking lobules); maculae distinct, forming a strongly contrasting network; pseudocyphellae absent $\ldots \ldots \ldots \ldots \ldots \ldots \ldots \ldots \ldots \ldots \ldots \ldots \ldots \ldots \ldots \ldots$. sipmanii

Thallus with soralia or polyisidiangia; maculae indistinct; pseudocyphellae present

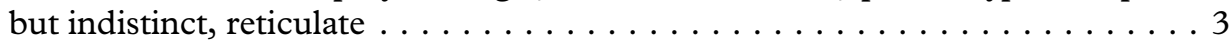

3(2) Soralia predominantly marginal, linear, finely granular; thallus surface more or

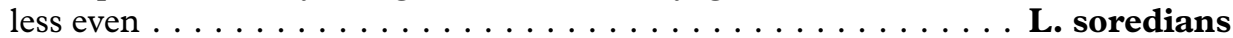

Soralia predominantly laminal, developing from weakly corticate polyisidiangia, coarsely granular; thallus surface shallowly to distinctly scrobiculate . . . . . . . . $\ldots \ldots \ldots \ldots \ldots \ldots \ldots \ldots \ldots \ldots \ldots \ldots \ldots \ldots \ldots \ldots \ldots$ botryoides

4(1) Thallus with apothecia, lacking isidia or phyllidia $\ldots \ldots \ldots \ldots \ldots \ldots \ldots$

Thallus with isidia or phyllidia, usually lacking apothecia. . . . . . . . . . 15

5(4) Chemosyndrome A1 (gyrophoric acid, methyl-gyrophorate, Lobariella unidentified 1, pseudocyphellarin A), medulla $\mathrm{K}$ - (or rarely $\mathrm{K}+$ yellow-brown), $\mathrm{C}+$ pink-red . 6

Chemosyndrome B (Lobariella unidentified 2 and 3, 4-O-methyl-gyrophoric acid, traces of gyrophoric acid, pseudocyphellarin $\mathrm{A}$ ), medulla $\mathrm{K}+$ emerald green to sordid yellow, $\mathrm{C}$ - or $\mathrm{C}+$ weakly or slowly salmon-rose . . . . . . . . . . 10

6(5) Pseudocyphellae absent; maculae present, forming a fine, reticulate network towards

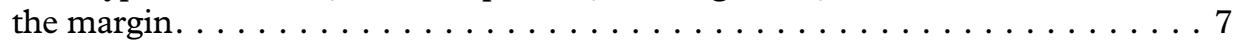

Pseudocyphellae present; maculae absent or only present at the margin, then discrete and conspicuous, not forming a reticulate network $\ldots \ldots \ldots \ldots$

7(6) Upper surface hypermaculate, especially towards the margin; lobes 10-20 mm wide, truncate; apothecial margin with 7-15 more or less regular lobules; thallus very loosely attached, growing in three dimensions and with the periphery distant from the substratum ('salad'-like); methyl-gyrophorate present . . . . . . . L. pallida 
Upper surface reticulate-maculate; lobes 5-10 mm wide, irregular; apothecial margin crisp, with 15-30 irregularly dissected lobules; thallus loosely attached, more or less following the substratum; methyl-gyrophorate absent . . . . . . L. reticulata

8(6) Lobes 10-20 mm wide; pseudocyphellae developing from marginal maculae; thallus loosely attached . . . . . . . . . . . . . . pallidocrenulata

Lobes 5-10 $\mathrm{mm}$ wide; pseudocyphellae present from the margin, with maculae absent; thallus more closely attached. . . . . . . . . . . . . . 9

9(8) Lobes regularly truncate, Parmelia-like; apothecial margin with 7-15 more or less regular lobules . . . . . . . . . . . . . . . . L. parmelioides

Lobes irregular; apothecial margin crisp, with 15-30 irregularly dissected lobules. . $\ldots \ldots \ldots \ldots \ldots \ldots \ldots \ldots \ldots \ldots \ldots \ldots \ldots \ldots \ldots$ crenulata

10(5) Medulla pale yellow, K+ yellow-orange to slowly red when drying; thallus delicate with lobes $1.5-3.0 \mathrm{~mm}$ wide; pseudocyphellae scattered, indistinct . . . . . . . .

$\ldots \ldots \ldots \ldots \ldots \ldots \ldots \ldots \ldots \ldots \ldots \ldots$. flavomedullosa

Medulla white but sometimes becoming pale yellow when exposed for prolonged time, $\mathrm{K}+$ emerald green to sordid yellow; thallus robust, with lobes $5-10(-20)$ $\mathrm{mm}$ wide; pseudocyphellae and/or maculae usually dense and distinct . . . . . 11

11(10) Lobes 3-5 mm wide, truncate, Parmelia-like . . . . . . . . . . . . . . . . 12

Lobes $5-15 \mathrm{~mm}$ wide, variously shaped . . . . . . . . . . . . . . 13

12(11) Upper surface smooth to uneven . . . . . . . . . . . . . L. angustata Upper surface distinctly rugulose-ridged . . . . . . . . . L. rugulosa

13(11) Pseudocyphellae present at margin, maculae absent; lobes rounded; thallus closely attached, more or less flat . . . . . . . . . . . . L. subcrenulata

Pseudocyphellae developing from marginal maculae; lobes irregular or truncate; thallus loosely attached or ascending. . . . . . . . . . . . . . 14

14(13) Lobes ascending, irregular, up to $15 \mathrm{~mm}$ wide, becoming olive in herbarium . . . . $\ldots \ldots \ldots \ldots \ldots \ldots \ldots \ldots \ldots \ldots \ldots \ldots$ olivascens

Lobes adnate, truncate, Parmelia-like, up to $10 \mathrm{~mm}$ wide, remaining yellow-grey in herbarium . . . . . . . . . . . . . . pseudocrenulata

15(4) Chemistry chemosyndrome A1 or A2 (gyrophoric and/or lecanoric acids, methylgyrophorate, Lobariella unidentified 1, pseudocyphellarin A), medulla K- (or rarely $\mathrm{K}+$ yellow-brown), $\mathrm{C}+$ pink-red; isidia or phyllidia usually concolourous

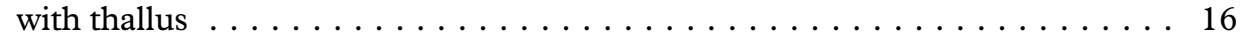

Chemosyndrome B (Lobariella unidentified 2 and 3, 4-O-methyl-gyrophoric acid, traces of gyrophoric acid, pseudocyphellarin $\mathrm{A}$ ), medulla $\mathrm{K}+$ emerald green to sordid yellow, C- or C+ weakly or slowly salmon-rose; isidia or phyllidia usually

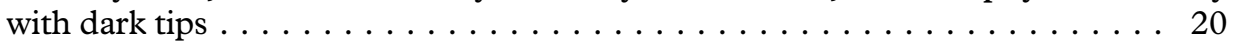

16 (15) Isidia cylindrical, at least the terminal branches . . . . . . . . . . . 17

Isidia flattened throughout or dorsiventral (phyllidia) $\ldots \ldots \ldots \ldots \ldots$

17(16) Isidia sparsely and dichotomously branched from the base, remaining more or less

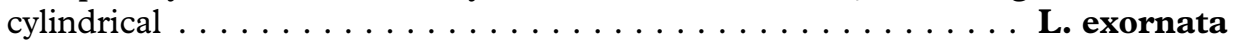

Isidia coralloid, with the lower portions flattened and only terminal branches cylindrical. . . . . . . . . . . . . . . . . . corallophora

18(16) Thallus with flattened isidia more or less equal on both sides; main medullary substance gyrophoric acid (chemosyndrome A1); lower tomentum pale brown . . . .

............................. . subexornata

Thallus with dorsiventral or peltate phyllidia; main medullary substance lecanoric acid (chemosyndrome A2); lower tomentum dark brown . . . . . . . . . . . 19 
19(18) Phyllidia erect to oblique, inserted at the base, with underside ecorticate. . . . . . . $\ldots \ldots \ldots \ldots \ldots \ldots \ldots \ldots \ldots \ldots \ldots \ldots \ldots \ldots \ldots$. ecorticata Phyllidia horizontal, peltate, attached by a central umbilicus, with underside corticate L. peltata

20(15) Isidia cylindrical or coralloid with flattened bases and cylindrical upper parts . . . 21

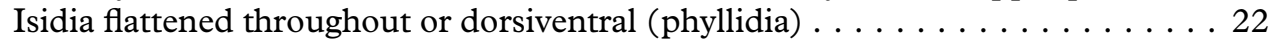

21(20) Isidia sparsely branched, entirely cylindrical; lobes 3-6 mm wide, truncate, Parmelialike; lower tomentum pale. . . . . . . . . . . . . . . . . L. isidiata

Isidia coralloid, base or lower part flattened but terminal branches remaining cylindrical; lobes 7-15 mm wide, irregular; lower tomentum dark.

L. subcorallophora

22(20) Isidia with fine papillae emerging from the cortical cells, therefore appearing velvetlike under the dissecting microscope; lobes truncate, Parmelia-like, 5-10 mm wide;

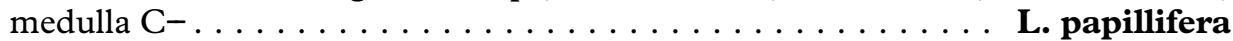

Isidia or phyllidia with smooth cortex; lobes rounded to irregular, 7-15 mm wide;

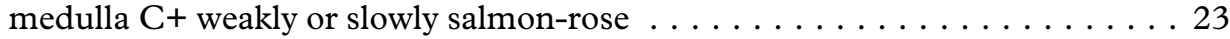

23(22) Thallus with dorsiventral phyllidia concolourous with thallus, lacking dark tips, usually emerging from the entire thallus surface and not restricted to pseudocyphellae, sparsely branched. . . . . . . . . . . . . . . . . . . . 24

Thallus with flattened isidia with dark tips, usually developing from pseudocyphellae or cracks derived from the latter; richly branched, in irregular groups . . . . . . 25

24(23) Isidia sparsely branched, sometimes becoming peltate, individual branches irregular in outline and up to $0.3 \mathrm{~mm}$ wide $\ldots \ldots \ldots \ldots \ldots$. $\ldots \ldots \ldots$ stenroosiae

Isidia richly branched, never peltate, individual branches linear and up to $0.2 \mathrm{~mm}$

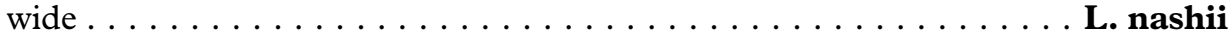

25(23) Lobes rounded; thallus underside pale; medulla C+ orange along pseudocyphellae,

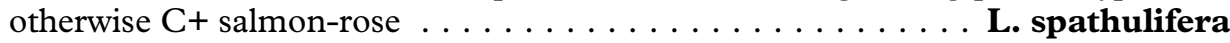

Lobes irregular; thallus underside dark; medulla $\mathrm{C}+$ weakly salmon-rose throughout

L. auriculata

\section{Lobariella angustata B. Moncada \& Lücking sp. nov.}

\section{MycoBank No.: MB801881}

Differing from Lobariella crenulata in the loosely attached rather than adnate thallus with narrow (3-5 $\mathrm{mm}$ vs $5-10$ mm wide) lobes, and the medullary chemistry, containing Lobariella unidentified 3 ( $\mathrm{K}+$ emerald green) instead of gyrophoric acid (C+ pink-red) as major compound.

Type: Colombia, Casanare, Chameza, eastern base of Cordillera Oriental, 600-800 m, 24-31 January 2012, Vargas $\&$ Herrera 310a (UDBC-holotype; F-isotype).

(Fig. 6A \& B)

Thallus growing on stems and branches of small trees, up to $5 \mathrm{~cm}$ diam., loosely attached between bryophytes and other lichens; photobiont green (Dictyochloropsis). In- dividual lobes up to $3 \mathrm{~cm}$ long, with rounded to irregular apices and sinuose margins, 3-5 $\mathrm{mm}$ wide, irregularly branched, forming irregular thallus rosettes. Upper surface greygreen when hydrated, pale grey when dry and becoming pale yellowish brown in the herbarium, smooth to slightly uneven towards the centre; maculae present in a very narrow zone $(1-2 \mathrm{~mm})$ along the lobe margins and apices, dense (about $10-15$ per $\mathrm{mm}^{2}$ ), irregular to elongate, $0 \cdot 1-0.5 \mathrm{~mm}$ long and $0.05-0.10 \mathrm{~mm}$ wide, soon developing into pseudocyphellae; pseudocyphellae developing from marginal maculae, dense (about 5-10 per $\mathrm{mm}^{2}$ ), visible as elongate to linear pores, $0 \cdot 2-1.0 \mathrm{~mm}$ long and $0 \cdot 1 \mathrm{~mm}$ wide, eventually forming fine cracks in the thallus surface. 

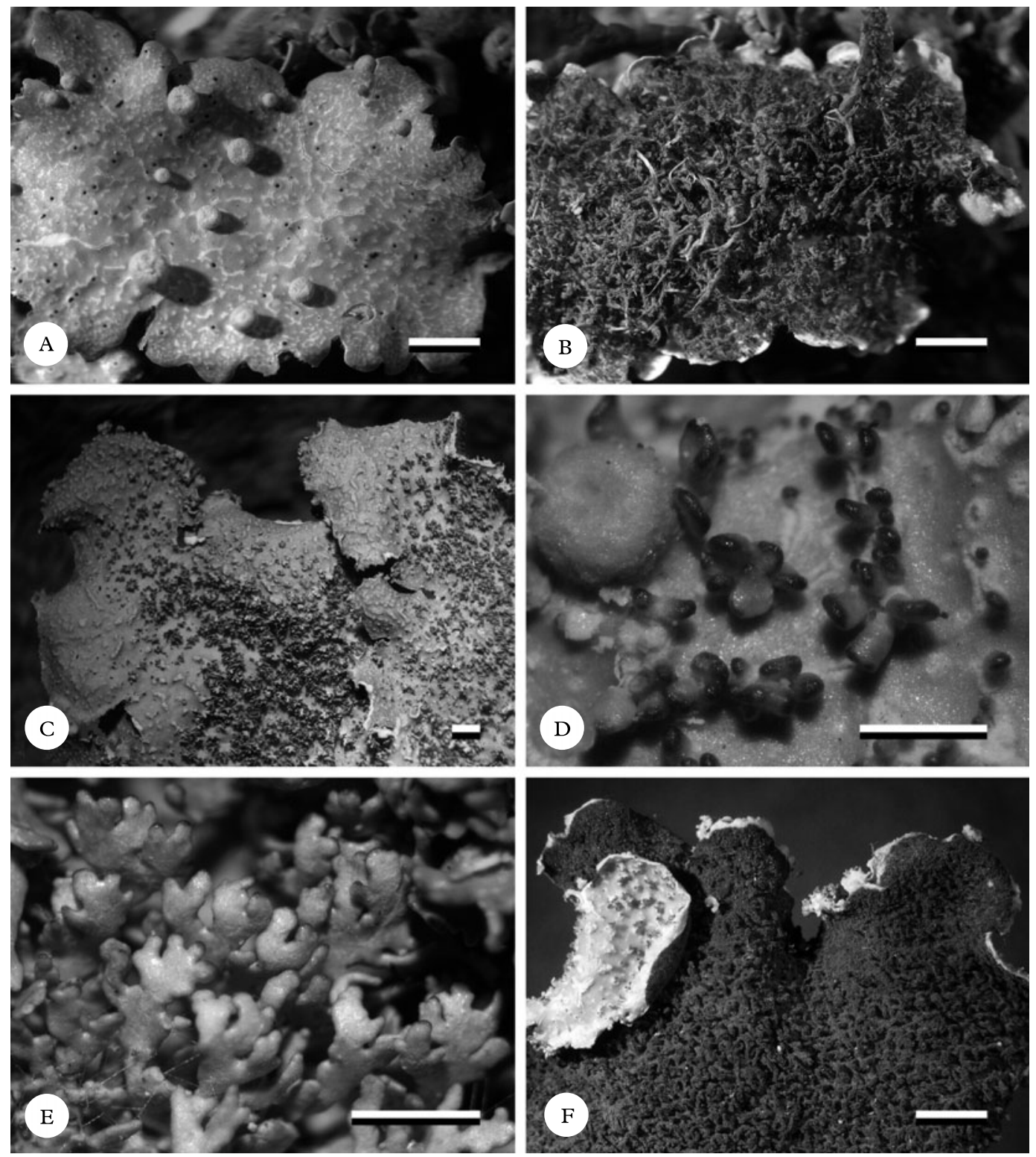

Fig. 6. Habit of Lobariella species. A \& B, L. angustata (holotype), showing upper side with pseudocyphellae (A) and lower side with dark rhizines (B); C-F, L. auriculata (C, F, holotype; D, E, Rodríguez E。 Zárate 32), showing upper side with pseudocyphellae (C), young (D) and fully developed isidia (E) and completely dark lower tomentum (F). Scale $=1 \mathrm{~mm}$.

Isidia absent. Lower surface cream-coloured, with a short, dense, cream-coloured tomentum formed of up to $30 \mu \mathrm{m}$ long hyphae composed of globose cells up to $5 \mu \mathrm{m}$ diam. and discrete, up to $2 \mathrm{~mm}$ long and $0.2 \mathrm{~mm}$ wide, grey-brown rhizines composed of strongly agglutinated, parallel hyphae; rhizines unbranched to sparsely branched at the tip and 
covered with tomentum. Upper cortex paraplectenchymatous, $15-25 \mu \mathrm{m}$ thick with 3-4 $\mu \mathrm{m}$ thick epicortex, formed of 3-4 cell layers; algal layer 15-25 $\mu \mathrm{m}$ thick; medulla $80-100$ $\mu \mathrm{m}$ thick; lower cortex paraplectenchymatous, 7-15 $\mu \mathrm{m}$ thick, formed of 2(-3) cell layers.

Apothecia abundant, cup-shaped, up to 3 $\mathrm{mm}$ diam., with thick, strongly prominent, lobulate, grey margins; lobules 7-15 per apothecium, more or less regular with rounded or rarely bifurcate tips; disc concave, orange-brown. Excipulum composed of more or less parallel, partly branched hyphae with wide lumina in part resembling a paraplectenchyma, 30-60 $\mu \mathrm{m}$ wide, hyaline; hypothecium formed of densely intricate, thin hyphae, $20-30 \mu \mathrm{m}$ high, pale yellowish. $\mathrm{Hy}$ menium 100-120 $\mu \mathrm{m}$ high, clear, with yelloworange, strongly conglutinated, 7-12 $\mu \mathrm{m}$ high epithecium; asci narrowly clavate, 90$100 \times 9-12 \mu \mathrm{m}$. Ascospores 8 per ascus, in a bundle, narrowly fusiform, $65-80 \times 3-4$ $\mu \mathrm{m}, 7$-septate, hyaline.

Pycnidia not observed.

Secondary chemistry. Chemosyndrome B: cortex with traces of pseudocyphellarin A, $\mathrm{K}+$ yellow; medulla with Lobariella unidentified 3 (major), 4-O-methyl-gyrophoric acid (major), gyrophoric acid (minor), and $\mathrm{Lo}$ bariella unidentified 2 (minor), $\mathrm{K}+$ emerald green to sordid yellow, C+ weakly salmonrose.

Ecology. In contrast to most other species of Lobariella, this new species appears to be a submontane to lower montane rainforest species, thus far known only by two collections from $600-800 \mathrm{~m}$ altitude, on branches of semi-shaded to semi-exposed trees.

Notes. This species was first identified as Lobariella crenulata (Yoshimura 1984, 1998; Yoshimura \& Arvidsson 1994), but the medullary chemistry is distinct, producing Lobariella unidentified 3 with $\mathrm{K}+$ emerald green medullary reaction as the major substance. Also, the pseudocyphellae develop from marginal maculae and are more delicate and dense than in L. crenulata (up to $1.0 \times 0.1$ vs $2.0 \times 0.2 \mathrm{~mm}$ ). The two known collections form a distinct, well-supported clade (Fig. 3). There are four other species with similar chemistry and apothecia, $L$. olivascens, L. pseudocrenulata, L. rugulosa and L. subcrenulata. These have broader lobes (5-20 mm) except for L. rugulosa which, however, differs in the rugulose-ridged upper surface. Thus far, L. angustata is known only from a small region in Colombia.

Additional specimen examined. Colombia: Casanare: Chameza, eastern base of Cordillera Oriental, 600800 m, 2012, Vargas $\mathcal{E}$ Herrera 281a (F, UDBC).

\section{Lobariella auriculata B. Moncada \& Lücking sp. nov.}

\section{MycoBank No.: MB801882}

Differing from Lobariella subexornata in the isidia arising predominantly from pseudocyphellae and forming irregular groups of flattened, apically darkened structures ('auriculae') when young, and in the medullary chemistry, with Lobariella unidentified 3 as the main substance.

Type: Colombia, Cundinamarca, Choachí, Vereda El Verjón, Parque Ecológico Matarredonda, trail to andine forest; $4^{\circ} 34^{\prime} \mathrm{N}, 74^{\circ} 00^{\prime} \mathrm{W}, 3000 \mathrm{~m}, 8$ May 2010 , Moncada 3075 (UDBC-holotype; F-isotype).

\section{(Fig. 6C-F)}

Thallus growing on trunks and stems, up to $10 \mathrm{~cm}$ diam., loosely attached; photobiont green (Dictyochloropsis). Individual lobes up to $5 \mathrm{~cm}$ long, with rounded to irregular apices and irregularly incised margins, 7-15 $\mathrm{mm}$ wide, irregularly branched, forming more or less irregular thallus rosettes. Upper surface bright green when hydrated, pale grey when dry and becoming pale yellowish brown in the herbarium, shallowly to distinctly ridged especially towards the centre; maculae absent; pseudocyphellae present from the lobe tips, usually on the ridges, moderately dense $\left(1-3\right.$ per $\left.\mathrm{mm}^{2}\right)$ starting out as irregular, white spots but soon becoming elongate-linear, up to $3 \mathrm{~mm}$ long and $0 \cdot 2-$ $0.3 \mathrm{~mm}$ wide and developing distinct linear cracks towards the centre. Isidia abundant, developing in groups on the pseudocyphellae or ridges, at first dark brown to brown-black and globose but soon becoming flattened with darkened tip, resembling the apothecial appendages of the crustose lichen Auriculora Kalb, then up to $0.07 \mathrm{~mm}$ thick and $0.2-$ $0.3 \mathrm{~mm}$ wide and high, eventually in older 
thallus parts up to $2 \mathrm{~mm}$ long and much branched, always remaining completely flattened and retaining the dark tips. Lower surface dark grey-brown, with a short, dense, dark grey-brown tomentum formed of up to $30 \mu \mathrm{m}$ long hyphae composed of globose cells up to $5 \mu \mathrm{m}$ diam. and discrete, up to $1 \mathrm{~mm}$ long and $0.15 \mathrm{~mm}$ wide, dark greybrown rhizines composed of strongly agglutinated, parallel hyphae; rhizines unbranched to sparsely branched at the tip and covered with tomentum towards the thallus centre. Upper cortex paraplectenchymatous, $20-30 \mu \mathrm{m}$ thick with 3-5 $\mu \mathrm{m}$ thick epicortex, formed of 3-5 cell layers; algal layer $15-25 \mu \mathrm{m}$ thick; medulla $80-130 \mu \mathrm{m}$ thick; lower cortex paraplectenchymatous, $7-15 \mu \mathrm{m}$ thick, formed of 2(-3) cell layers.

Apothecia and pycnidia not observed.

Secondary chemistry. Chemosyndrome B: cortex with pseudocyphellarin A, K+ yellow; medulla with Lobariella unidentified 3 (major), 4-O-methyl-gyrophoric acid (major), gyrophoric acid (minor), and Lobariella unidentified 2 (minor), $\mathrm{K}+$ emerald green to sordid yellow, $\mathrm{C}+$ weakly salmon-rose.

Ecology. This species is known from five collections in Colombia and Peru, and is probably widespread in the Andes. It grows mostly in the subandine zone close to the tree line, on tree trunks and branches in semi-shaded to semi-exposed situations.

Notes. This species is very similar to Lobariella subexornata (Yoshimura 1984, 1998; Yoshimura \& Arvidsson 1994) and agrees with the latter in general thallus morphology, including the flattened isidia. Without sequence data, we would have identified the material as that species, but results from the molecular studies prompted us to study potential morphological differences in more detail. Indeed, the isidia show various differences in their development and external morphology. In L. subexornata, they develop individually from the thallus surface, without any apparent relationship with pseudocyphellae; they are uniform in colour without a darkened tip, are flattened from the very beginning, and remain comparatively short with few branches usually from the base. In contrast, isidia in L. auriculata always develop from pseudocyphellae and form characteristic, irregular groups of 2-6 isidia oriented in different directions, and typically have dark tips. Isidia in older parts of the thallus become very long and richly branched, much more so than in L. subexornata. These differences correlate with a different medullary chemistry, since $L$. subexornata belongs to chemosyndrome $\mathrm{A} 1$, producing gyrophoric acid as a major substance (Yoshimura 1984; Yoshimura \& Arvidsson 1994). A similar species is L. spathulifera, which has isidia similar to those of L. auriculata, but it has a pale underside and an additional, unknown medullary substance which reacts patchily $\mathrm{C}+$ orange along some of the pseudocyphellae. Isidia with dark tips are also found in $L$. corallophora and L. isidiata; however, in those species, the isidia remain cylindrical except for the flattened base in branched isidia of $L$. corallophora. Another similar species is $L$. ecorticata, which can be distinguished by the lack of a cortex on the lower side of the isidia, as well as the medullary chemistry of chemosyndrome A2, which includes lecanoric acid as the major medullary substance. Both $L$. auriculata and $L$. ecorticata have a dark lower tomentum, in contrast to most other species in the genus which have a pale underside.

Additional specimens examined. Colombia: Boyacá: Villa de Leyva, Santuario de Fauna y Flora Iguaque, trail from administrative building to Villa de Leyva, 28002850 m, 2000, Moncada \& Dávila 832 (UDBC). Cundinamarca: Santa Fé, 2009, Rodríguez E Zárate 32 (UDBC). Norte de Santander: Parque Nacional Natural Tamá, Sector Orocué, 2800 m, 2000, Moncada E Dávila 1021b (UDBC); ibid., 2000, Moncada E Dávila 1112b, 1125 (UDBC).-Ecuador: Pichincha: Río Guajalito Protection Forest, along old road from Quito to Santo Domingo de los Colorados, 2400 m, 2008, Lücking 26215b (F, QCNE).-Peru: Cuzco: Urubamba, 4 viii 2009, Lücking s. n. (CUZ).

\section{Lobariella botryoides Yoshim. \& Arv.}

Acta Bot. Fenn. 150: 226 (1994); type: Ecuador, Arvidsson et al. 6072 (GB-holotype).

\section{(Fig. 7A \& B)}

Notes. For a detailed description of this species, see Yoshimura \& Arvidsson (1994). Lobariella botryoides is one of three species 

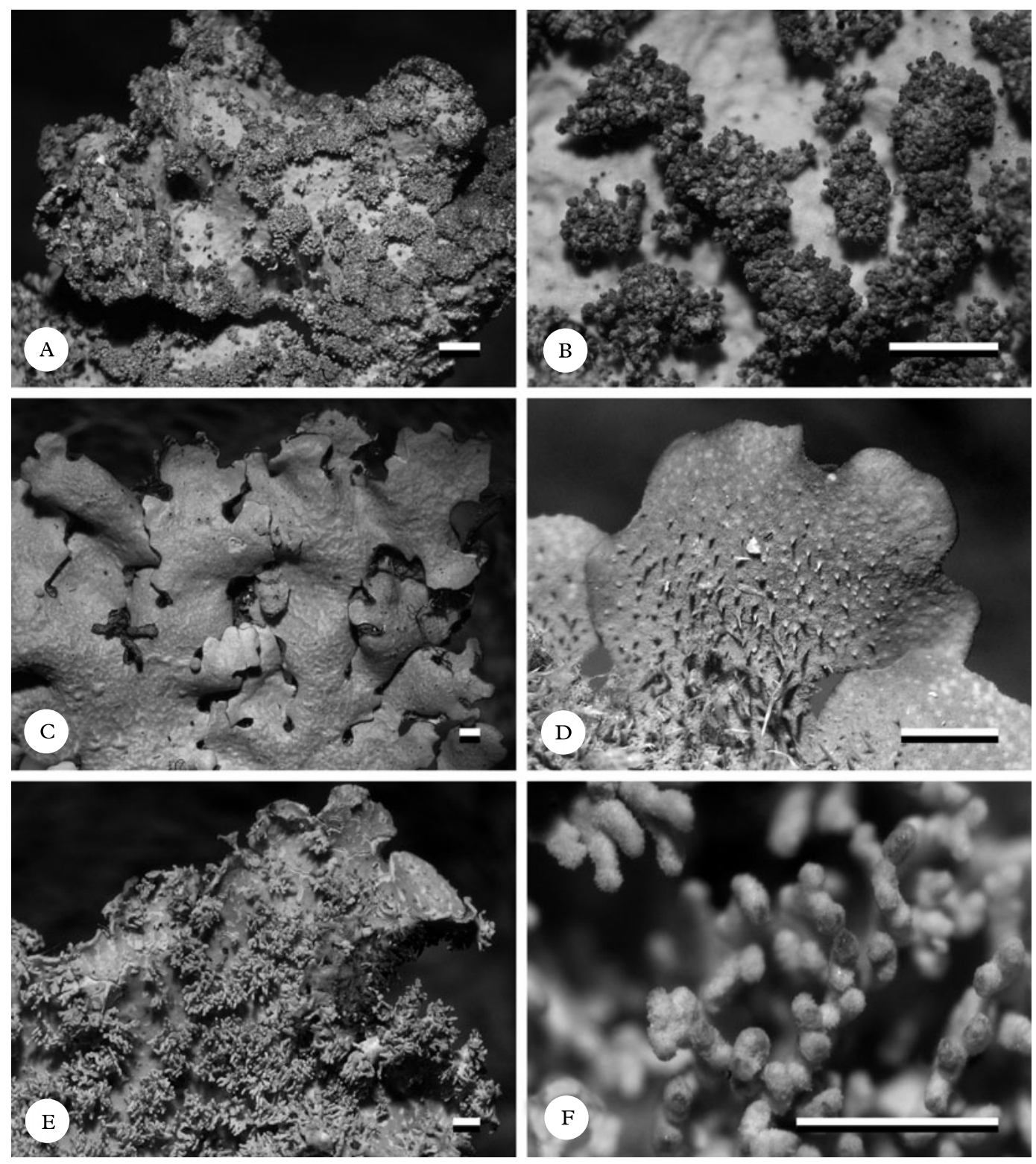

FIG. 7. Habit of Lobariella species. A \& B, L. botryoides (Moncada 4650), showing upper side with sorediate dactyls (A) and dactyls enlarged (B); C \& D, L. crenulata (C, Diáz Escandón \& Soto L9; D, Moncada 2084), showing upper (C) and lower (D) sides; E \& F, L. ecorticata (holotype), showing upper side with pseudocyphellae and phyllidia (E) and enlarged, partially ecorticate phyllidia with fuzzy surface $(F)$. Scale $=1 \mathrm{~mm}$.

with a cyanobacterial photobiont and is readily distinguished by its predominantly laminal soralia developing from polyisidiangia or dactyls with poorly developed cortex.
The species produces indistinct, reticulate pseudocyphellae at the lobe tips that soon develop into cracks, and the lobe tips are often darkened; in addition, the thallus sur- 
face is shallowly to distinctly scrobiculate. Lobariella soredians can be confused with $L$. botryoides, but is readily separated by the marginal, true soralia not developing from polyisidiangia, and the more or less even thallus surface; the two species do not appear to be closely related genetically. Lobariella sipmanii, the third cyanobacterial species, produces apothecia instead of soralia. All three have a similar chemistry of chemosyndrome A1 (a or b) with gyrophoric acid as the major medullary substance (medulla $\mathrm{C}+$ pink-red).

Lobariella botryoides is known from Colombia and Ecuador and occurs on twigs and thin stems of shrubs and treelets in the páramo and the immediately adjacent, subandine cloud (elfin) forest. It does not seem to be abundant but may be overlooked due to its generally small size and inconspicuous, grey colour.

Specimens examined. Colombia: Cundinamarca: Parque Nacional Natural Chingaza, 3100-3600 m, 2011, Moncada 4650 (UDBC); Parque Nacional Natural Sumapáz, 3500-3700 m, 2008, Ardila E Gómez 190 (UDBC); ibid., 2010, Moncada 4081 (UDBC); Zona de Amortiguación (Mundo Nuevo), Parque Nacional Natural Chingaza, 2900-3100 m, 2011, Moncada 4986 (UDBC); Reserva Natural Nacimiento del Río Bogotá, Páramo de Guacheneque, 3200 m, 2012, Moncada 5481 (F, UDBC).

\section{Lobariella corallophora (Yoshim.) B. Moncada \& Lücking comb. et stat. nov.}

\section{MycoBank No.: MB801883}

Lobaria exornata var. corallophora Yoshim., f. Hattori Bot. Lab. 57: 112 (1984); type: Costa Rica, Yoshimura 79816 (NICH-holotype, not seen).

Notes. For a description of this species (as a variety of $L$. exornata), see Yoshimura (1984). Unfortunately we have not been able to revise the type material, as it was not found in NICH or hb. Yoshimura (I. Yoshimura, pers. comm. 2012). According to its description, this is the only species known in the genus with partially flattened isidia with cylindrical terminal branches and a chemosyndrome A1 medullary chemistry. Pseudocyphellarin A was not detected in the type using TLC, although the material was described as having a $\mathrm{K}+$ yellow cortical reaction (Yoshimura 1984). Lobariella subcorallophora has similar isidia but a chemosyndrome B medullary chemistry.

This taxon is known only from the type from the Costa Rican subandine cloud (elfin) forest and páramo zone.

\section{Lobariella crenulata (Hook.) Yoshim.}

in Nash et al., Lichen Flora of the Greater Sonoran Desert Region 1: 271 (2002).—Parmelia crenulata Hook. in Kunth, Syn. Pl. Aequinoct. Otb. Nov. 1: 23 (1822).Sticta crenulata (Hook.) Delise, Hist. Lich. Sticta: 128 (1822).-Lobaria crenulata (Hook.) Trevis., Lichenoth. Veneta: 75 (1869).-Durietzia crenulata (Hook.) Yoshim. in Marcelli \& Ahti, Recollecting Edvard August Vainio: 91 (1998); type: South America, Humboldt 120 (BMholotype!; PC-isotype!).

(Fig. 7C \& D)

Notes. For a detailed description of this species, see Yoshimura (1984) and Yoshimura \& Arvidsson (1994). Based on the type and the material sequenced here, Lobariella crenulata is characterized by a more or less closely attached thallus with rather narrow lobes (5-10 $\mathrm{mm}$ wide) and more or less rounded to irregular lobe tips, discrete pseudocyphellae on the upper surface, apothecia with irregularly lobulate margins, with 15-30 lobules with crisp tips per apothecium, and a pale underside with long, irregular rhizines. The species does not form corticate maculae; instead, the pseudocyphellae, even if appearing as white spots at the lobe tips, are ecorticate from the beginning and soon open with fine, linear cracks. The chemistry is of chemosyndrome A1a, similar to that of L. pallida, including gyrophoric acid, methyl-gyrophorate, and pseudocyphellarin $\mathrm{A}$ as major substances (isotype in PC analyzed with TLC). There are five other species with green photobiont and apothecia, lacking vegetative propagules, and having a similar chemistry: L. flavomedullosa has a pale yellow, $\mathrm{K}+$ yellow turning slowly red medulla; L. pallida and $L$. reticulata have reticulate maculae and lack pseudocyphellae; L. pallidocrenulata has much broader lobes and the pseudocyphellae develop from marginal maculae; and $L$. parmelioides differs subtly by the truncate, Parmelia-like lobules 
and apothecia with less numerous, more regularly rounded lobules. With the exception of L. flavomedullosa, these species are closely related but are nevertheless specifically distinct, both phylogenetically and morphologically (Fig. 3).

Lobariella crenulata appears to be an upper montane to subandine species found in more or less semi-exposed microsites on branches and sometimes the trunk of trees. It does not seem to extend regularly into the páramo zone.

Specimens examined. Colombia: Cauca: Parque Nacional Natural Puracé, 3200-3500 m, 2011, Díaz E Soto L9 (F, UDBC). Cundinamarca: Choachí, Vereda El Verjón, Parque Ecológico Matarredonda, trail to andine forest, $4^{\circ} 34^{\prime} \mathrm{N}, 74^{\circ} 00^{\prime} \mathrm{W}, 3000 \mathrm{~m}, 2007$, Castro et al. 128 (UDBC); ibid., 2011, Moncada 4614b (UDBC). Norte de Santander: Parque Nacional Natural Tamá, Sector Orocué, 2800 m, 2000, Moncada E Dávila 1244 (UDBC). Risaralda: Pereira, Vereda La Suiza, Santuario de Fauna y Flora Otún Quimbaya, surroundings of visitor centre, $2300 \mathrm{~m}, 2003$, Moncada $\mathcal{E}$ Dávila 2084 (UDBC).

\section{Lobariella ecorticata B. Moncada \& Lücking sp. nov.}

\section{MycoBank No.: MB801884}

Differing from Lobariella corallophora in the coralloid phyllidia with flattened, broad base which are ecorticate on the underside, the dark lower tomentum, and the chemosyndrome A2 medullary chemistry with lecanoric instead of gyrophoric acid as the major compound.

Type: Colombia, Cundinamarca, Choachí, Vereda El Verjón, Parque Ecológico Matarredonda, trail to andine forest, $4^{\circ} 34^{\prime} \mathrm{N}, 74^{\circ} 00^{\prime} \mathrm{W}, 3000 \mathrm{~m}$, May 2010 , Moncada 3156 (UDBC-holotype; F-isotype).

\section{(Fig. 7E \& F)}

Thallus growing on trunks and stems, up to $12 \mathrm{~cm}$ diam., closely attached; photobiont green (Dictyochloropsis). Individual lobes up to $5 \mathrm{~cm}$ long, irregular with more or less truncate apices and irregularly incised margins, 5-10 $\mathrm{mm}$ wide, irregularly branched, forming a more or less irregular thallus. Upper surface bright green when hydrated, pale grey when dry and becoming pale yellowish brown in the herbarium, even or with cracks in older parts; maculae absent; pseudocyphellae present from the lobe tips, starting out as minute, irregular, white spots $0.10 \times 0.05 \mathrm{~mm}$ diam. but soon becoming elongate-linear, up to 1 $\mathrm{mm}$ long and $0 \cdot 1 \mathrm{~mm}$ wide and developing linear cracks in the centre. Phyllidia abundant, developing along the pseudocyphellae, at first forming irregular granules concolorous with the thallus, $0 \cdot 07-0 \cdot 10 \mathrm{~mm}$ diam., soon branching and becoming coralloid with flattened base and cylindrical to slightly flattened terminal branches, up to $2 \mathrm{~mm}$ long and $0.1 \mathrm{~mm}$ wide, the upper side corticate and concolorous with the thallus and the lower side ecorticate and white. Lower surface pale brown, becoming blackened towards the centre, with a very short, dense, dark brown tomentum formed of up to $25 \mu \mathrm{m}$ long hyphae composed of globose cells up to $5 \mu \mathrm{m}$ diam., and dense but discrete, up to $1 \mathrm{~mm}$ long and $0.1 \mathrm{~mm}$ wide, grey-black rhizines composed of strongly agglutinated, parallel hyphae; rhizines unbranched to irregularly branched and covered with tomentum. Upper cortex paraplectenchymatous, 30-40 $\mu \mathrm{m}$ thick with 3-5 $\mu \mathrm{m}$ thick epicortex, formed of 4-6 cell layers; algal layer 15-25 $\mu \mathrm{m}$ thick; medulla 100-150 $\mu \mathrm{m}$ thick; lower cortex paraplectenchymatous, $10-15 \mu \mathrm{m}$ thick, formed of 2-3 cell layers.

Apothecia and pycnidia not observed.

Secondary chemistry. Chemosyndrome A2: cortex with pseudocyphellarin A, K+ yellow; medulla with lecanoric acid (major), methyllecanorate (trace), and Lobariella unidentified 1 (major), $\mathrm{K}-$ or $\mathrm{K}+$ yellow-brown, $\mathrm{C}+$ red.

Ecology. This new species is only known from the type collection and therefore not much can be said about its ecology, other than it seems to be a transitional species between subandine cloud forest and andine páramo.

Notes. This species is unusual in producing flattened-coralloid phyllidia with an ecorticate underside. All other isidiate species in the genus have completely corticate isidia. The propagules of Lobariella ecorticata are classified as phyllidia but not as lobules, since their underside is anatomically different from the thallus underside. Another unusual feature is the blackened rhizines; in all other species, the rhizines are at least marginally pale but may become dark towards the thallus centre. Most similar in gross 
morphology are L. corallophora (Yoshimura 1984) and L. subcorallophora, which have coralloid isidia with flattened base, but their isidia are completely corticate and have dark tips and their medullary chemistry is different. A species with identical chemistry and lobe morphology is L. peltata, but this differs in the peltate, fully corticate isidia. Lobariella ecorticata is genetically quite distinct, representing the species with the longest branch in the genus, based on ITS data (Fig. 3).

\section{Lobariella exornata (Zahlbr.) Yoshim.}

in Nash et al., Lichen Flora of the Greater Sonoran Desert Region 1: 271 (2002).-Lobaria crenulata var. exornata Zahlbr., Ann. Mycol. 19: 235 (1921)._Lobaria exornata (Zahlbr.) Yoshim., f. Hattori Bot. Lab. 57: 109 (1984).Durietzia exornata (Zahlbr.) Yoshim. in Marcelli \& Ahti, Recollecting Edvard August Vainio: 91 (1998); type: Jamaica, Plitt 67 (W-holotype, not seen; US - isotype!).

(Fig. 8A-C)

Notes. For a detailed description of this species, see Yoshimura (1984) and Yoshimura \& Arvidsson (1994). Lobariella exornata is similar to L. crenulata in thallus morphology (including the lack of corticate maculae). Apothecia are very rare and the ascospores seem to be broader than in $L$. crenulata (about $90-105 \times 7-9 \mu \mathrm{m}$ vs $70-100 \times 5-6$ $\mu \mathrm{m})$. The main difference is the presence of rather large, cylindrical to rarely slightly flattened, unbranched to sparsely dichotomously branched isidia (branching often near the base); the isidia are up to $0.5 \mathrm{~mm}$ long and $0.1 \mathrm{~mm}$ wide and concolorous with the thallus. The chemistry conforms to L. crenulata and relatives (chemosyndrome A1b), with gyrophoric acid as the main medullary substance and additionally pseudocyphellarin A. The only other species with a green photobiont and cylindrical isidia is $L$. isidiata, which differs in the less robust thallus lobes with a ridged to scrobiculate surface and the isidia starting out as dark brown to blackened, globose initials and retaining the dark tips when mature, and also has a different medullary chemistry of chemosyndrome B, producing Lobariella unidentified 3 as the major compound. Lobariella corallophora might be confused with $L$. exornata, but its isidia become strongly branched with flattened base and retain dark tips. In the development, colour, and branching of the isidia, $L$. exornata is most similar to L. subexornata, except that in the latter, the isidia are flattened.

Lobariella exornata is a rather common and widespread species, mostly found in lower montane and montane rainforest on tree trunks and larger branches, in semi-shaded to semi-exposed situations.

Specimens examined. Costa Rica: Heredia: Valle Central, Carrizal, 1900 m, 2002, Lücking 15525a (F, INB). Puntarenas: La Amistad International Park, Cerro Biolley, Sabanas Esperanza, 1300-1400 m, 2002, Lücking 15298c (F, INB, USJ); ibid., Las Alturas, 1550 m, 2012, Moncada 5725 (F, UDBC).-Colombia: Boyacá: Gachantivá, Laguna Las Coloradas, 2450 m, 1999, Moncada E Dávila 414 (UDBC). Cauca: Parque Nacional Natural Puracé, 3200-3500 m, 2011, Díaz Eீ Soto L12 (F, UDBC). Norte de Santander: Parque Nacional Natural Tamá, Sector Orocué, 2800 m, 2000, Moncada \& Dávila 1021a, 1080, 1219 (UDBC). Quindío: Santa Rosa de Cabal, 2970 m, 2003, Moncada E Dávila 1982 (UDBC).-Bolivia: La Paz: Yungas, 2800 m, 2007, Lücking 23513 (F, LPB).-Brazil: Minas Gerais: Parque Nacional de Itatiaia, 2000 m, 1997, Stenroos 5088a (H).

\section{Lobariella flavomedullosa B. Moncada, Betancourt-Macuase \& Lücking sp. nov.}

\section{MycoBank No.: MB801885}

Differing from Lobariella angustata in the pale yellow medulla and the very narrow lobes $(1 \cdot 5-3 \cdot 0 \mathrm{~cm}$ vs $3-5$ $\mathrm{mm})$.

Type: Colombia, Cundinamarca, Choachí, Vereda El Verjón, Parque Ecológico Matarredonda, trail to andine forest, $4^{\circ} 34^{\prime} \mathrm{N}, 74^{\circ} 00^{\prime} \mathrm{W}, 3000 \mathrm{~m}, 23$ January 2011 , Moncada s.n. (UDBC-holotype; F-isotype).

\section{(Fig. 8D-F)}

Thallus growing on thin trunks, stems, and branches, up to $6 \mathrm{~cm}$ diam., closely attached; photobiont green (Dictyochloropsis). Individual lobes up to $2.5 \mathrm{~cm}$ long, irregular to dichotomous with more or less truncate apices and entire to shallowly incised margins, $1 \cdot 5-3 \cdot 0$ $\mathrm{mm}$ wide, irregularly branched, forming more or less circular thallus rosettes. Upper surface bright green when hydrated, grey when dry and becoming pale yellowish brown in the herbarium, uneven to shallowly ridged; maculae absent; pseudocyphellae present from the lobe tips, starting out as minute, irregular, white spots $0.10 \times 0.03 \mathrm{~mm}$ diam., remaining indistinct and becoming elongate-linear, up to $0.7 \mathrm{~mm}$ long and $0.05 \mathrm{~mm}$ wide, 

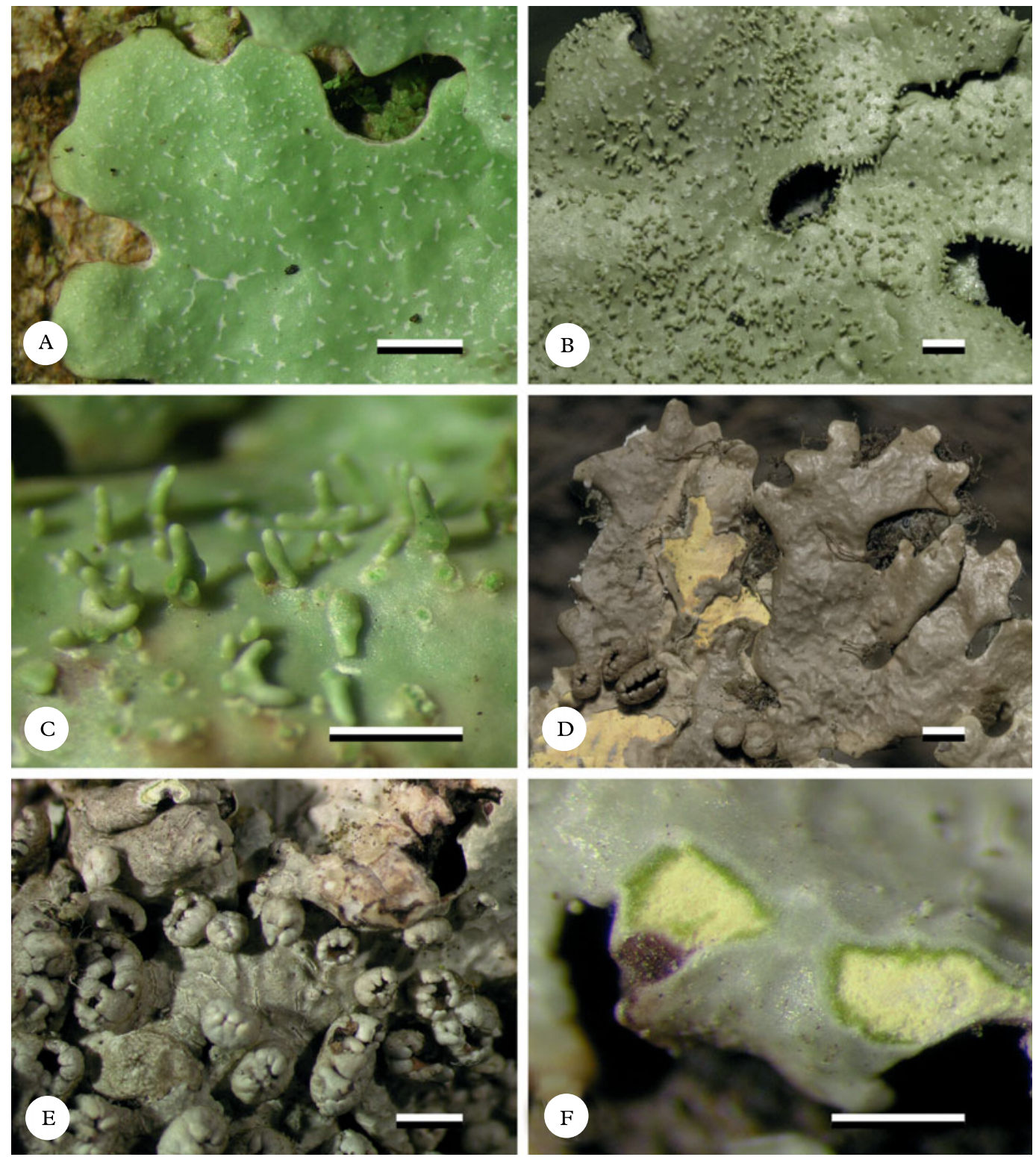

FIg. 8. Habit of Lobariella species. A-C, L. exornata (A, C, Lücking 15525a; B, Moncada 414), showing upper side with pseudocyphellae (A) and isidia (B) and isidia enlarged (C); D-F, L. flavomedullosa (D, Moncada 1802; E-F, holotype), showing upper side with exposed, pigmented medulla (D), apothecia (E), and close-up of pigmented medulla $(F)$. Scale $=1 \mathrm{~mm}$. In colour online.

developing indistinct linear cracks in the centre. Isidia absent. Lower surface creamcoloured to pale yellowish brown, with a very short to almost indistinct, pale yellowish brown tomentum formed of up to $20 \mu \mathrm{m}$ long hyphae composed of globose cells up to $5 \mu \mathrm{m}$ diam., and discrete, up to $1 \mathrm{~mm}$ long and $0 \cdot 1 \mathrm{~mm}$ wide, dirty yellowish brown rhi- 
zines composed of strongly agglutinated, parallel hyphae; rhizines unbranched to sparsely branched at the tips and covered with tomentum. Upper cortex paraplectenchymatous, $20-30 \mu \mathrm{m}$ thick with $4-5 \mu \mathrm{m}$ thick epicortex, formed of 3-5 cell layers; algal layer 15-20 $\mu \mathrm{m}$ thick; medulla $70-100$ $\mu \mathrm{m}$ thick, pale yellow; lower cortex paraplectenchymatous, $7-10 \mu \mathrm{m}$ thick, formed of 2 cell layers.

Apothecia abundant, cup-shaped, up to 2 $\mathrm{mm}$ diam., with thick, strongly prominent, lobulate, grey to cream-coloured margins; lobules 7-15 per apothecium, more or less regular with rounded or rarely bifurcate tips; disc concave, reddish brown. Excipulum composed of more or less parallel, partly branched hyphae with wide lumina resembling a paraplectenchyma, $40-60 \mu \mathrm{m}$ wide, hyaline; hypothecium formed of densely intricate hyphae partially resembling a paraplectenchyma, 20-30 $\mu \mathrm{m}$ high, pale yellowish. Hymenium 120-130 $\mu \mathrm{m}$ high, clear, with yellow-orange, strongly conglutinated, 10$20 \mu \mathrm{m}$ high epithecium; asci narrowly clavate, 100-120 $\times 9-12 \mu \mathrm{m}$. Ascospores narrowly fusiform, 60-80 × 3-4 $\mu \mathrm{m}, 7$-septate, hyaline.

Pycnidia not observed.

Secondary chemistry. Chemosyndrome B: cortex with pseudocyphellarin A, K+ yellow; medulla with Lobariella unidentified 3 (major), 4-O-methyl-gyrophoric acid (major), gyrophoric acid (minor), and Lobariella unidentified 2 (trace), $\mathrm{K}+$ sordid yellow slowly turning red, $\mathrm{C}+$ salmon-rose.

Ecology. This apparently rare, but possibly overlooked, small species is found on branches and twigs of trees in the upper montane to subandine cloud forest zone, in semi-shaded to semi-exposed microsites.

Notes. This new species resembles Lobariella crenulata but has narrow lobes $(1 \cdot 5-3 \cdot 0$ $\mathrm{mm}$ vs $5-10 \mathrm{~mm}$ ) and a different medullary chemistry including a pale yellow, $\mathrm{K}+$ red pigment. It also has a shallowly ridged thallus surface, as well as indistinct, scattered pseudocyphellae. The species is most similar to L. angustata and L. rugulosa, which have a white medulla and broader lobes $(3-5 \mathrm{~mm})$.
Lobariella flavomedullosa is thus far known only from Colombia.

Additional specimens examined. Colombia: Boyacá: Gachantivá, Vereda La Ciénaga, 2300 m, 2001, Moncada E Dávila 1802 (UDBC). Cundinamarca: Santa Fé, 2670 m, 2009, Rodríguez E Zárate 37 (F, UDBC).

\section{Lobariella isidiata B. Moncada \& Lücking sp. nov.}

\section{MycoBank No.: MB801886}

Differing from Lobariella exornata in the shallowly to distinctly scrobiculate to ridged thallus surface and the apically brown-black, initially globose isidia, as well as the chemosyndrome B medullary chemistry, with Lobariella unidentified 3 ( $\mathrm{K}+$ emerald green) instead of gyrophoric acid (C+ pink-red) as major compound.

Type: Colombia, Boyacá, Villa de Leyva, Santuario de Fauna y Flora Iguaque, trail from administrative building to Villa de Leyva, 2800-2850 m, October 2002, Moncada \& Dávila 1641 (UDBC-holotype; F-isotype).

\section{(Fig. 9A \& B)}

Thallus growing on trunks and stems, up to $8 \mathrm{~cm}$ diam., closely attached; photobiont green (Dictyochloropsis). Individual lobes up to $3 \mathrm{~cm} \mathrm{long,} \mathrm{irregular} \mathrm{with} \mathrm{more} \mathrm{or} \mathrm{less}$ truncate apices and shallowly crenulate margins, 3-6 $\mathrm{mm}$ wide, irregularly branched, forming more or less circular thallus rosettes. Upper surface bright green when hydrated, pale grey when dry and becoming pale yellowish brown in the herbarium with the tips darkened, shallowly to distinctly scrobiculate with foveolae $0.3-0.8 \mathrm{~mm}$ diam.; maculae absent; pseudocyphellae present from the lobe tips, starting out as minute, irregular, white spots $0.10 \times 0.03 \mathrm{~mm}$ diam. but soon becoming elongate-linear up to $2 \mathrm{~mm}$ long and $0.15 \mathrm{~mm}$ wide and developing distinct linear cracks in the centre. Isidia abundant, developing on the pseudocyphellae or bordering the foveolae, at first dark brown to brownblack and globose, 0.05-0.08 $\mathrm{mm}$ diam., becoming cylindrical towards the thallus centre, up to $0.8 \mathrm{~mm}$ long and $0.1 \mathrm{~mm}$ wide and retaining a dark brown to brown-black tip, remaining unbranched or becoming sparsely dichotomously branched. Lower surface cream-coloured to pale yellowish brown, with a very short, dense, pale yellowish brown tomentum formed of up to $25 \mu \mathrm{m}$ 

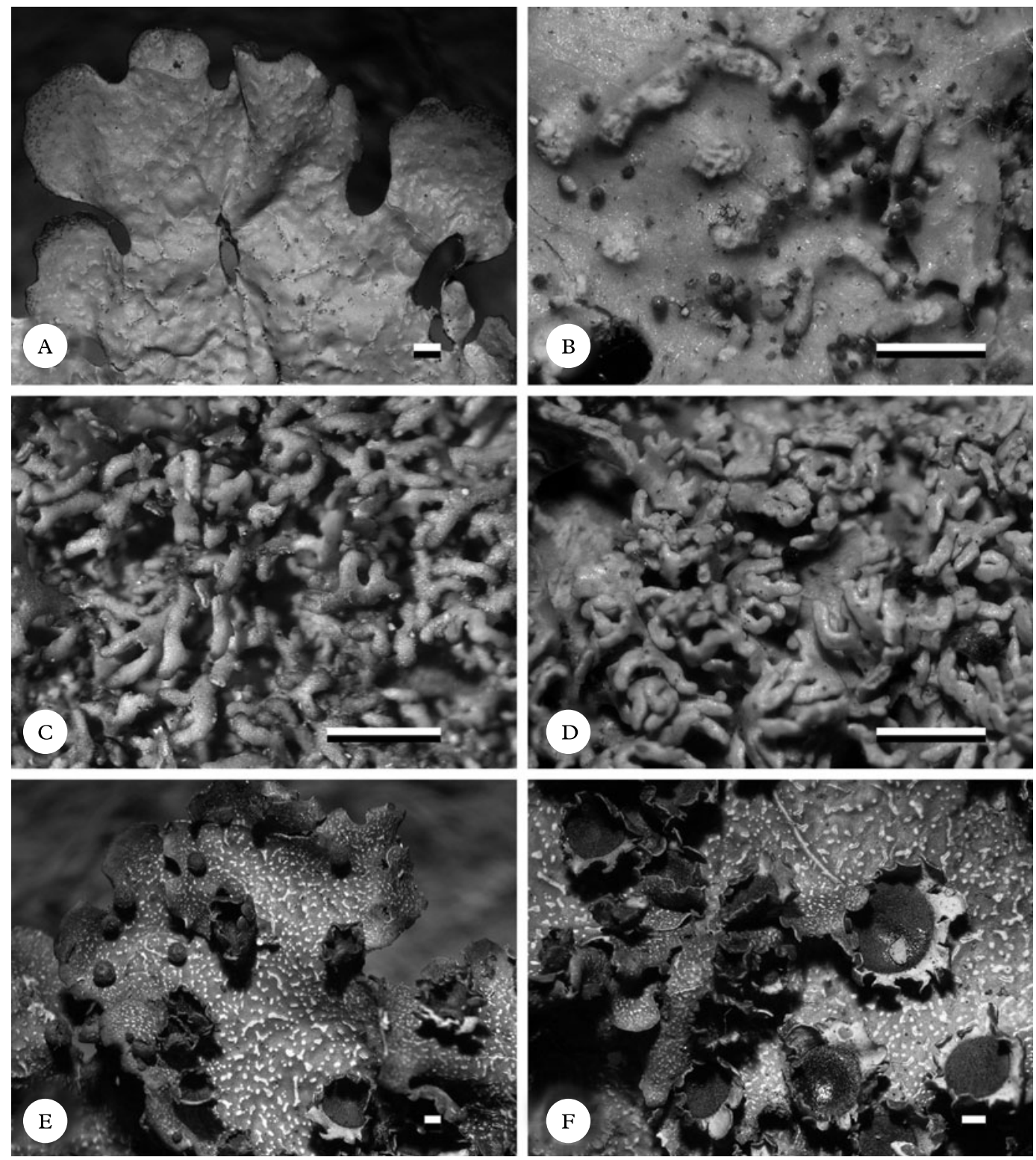

FIG. 9. Habit of Lobariella species. A \& B, L. isidiata (holotype), showing upper side (A) and isidia enlarged (B); C \& D, L. nashii (C, holotype; D, Moncada \& Dávila 1112b), showing phyllidia enlarged; E \& F, L. olivascens (holotype), showing upper side with maculae and pseudocyphellae (E) and apothecia (F). Scale $=1 \mathrm{~mm}$.

long hyphae composed of globose cells up to $5 \mu \mathrm{m}$ diam. and scattered, up to $0.7 \mathrm{~mm}$ long and $0.07 \mathrm{~mm}$ wide, white rhizines composed of strongly agglutinated, parallel hyphae; rhizines unbranched to sparsely branched at the tip and covered with tomentum towards the thallus centre. Upper cortex paraplectenchymatous, $20-30 \mu \mathrm{m}$ thick with $3-5 \mu \mathrm{m}$ thick epicortex, formed of 3-5 cell layers; algal layer 15-20 $\mu \mathrm{m}$ thick; medulla 80- 
$120 \mu \mathrm{m}$ thick; lower cortex paraplectenchymatous, $7-13 \mu \mathrm{m}$ thick, formed of $2(-3)$ cell layers.

Apothecia and pycnidia not observed.

Secondary chemistry. Chemosyndrome B: cortex with traces of pseudocyphellarin A, $\mathrm{K}+$ yellow; medulla with Lobariella unidentified 3 (major), 4-O-methyl-gyrophoric acid (major), gyrophoric acid (minor), and $\mathrm{Lo}^{-}$ bariella unidentified 2 (minor), $\mathrm{K}+$ emerald green to sordid yellow, C+ weakly salmonrose.

Ecology. Known only from the type collected in upper montane rainforest.

Notes. This species would key out as Lobariella exornata using the keys of Yoshimura (1984, 1998) and Yoshimura \& Arvidsson (1994). However, it differs from that species in the narrower lobes with darkened tips (5$10 \mathrm{~mm}$ wide in L. exornata) and the scrobiculate to ridged thallus surface (smooth and even in $L$. exornata, except for cracks and ridges in old thallus parts formed of the pseudocyphellae), as well as the medullary chemistry (chemosyndrome A1 in $L$. exornata). The isidia in L. isidiata develop as dark, globose initials and eventually become cylindrical with dark tips, whereas in L. exornata the isidia start out as irregular, ovoid to elongate initials of the same colour as the thallus, and only slightly darken at the tip with age. The combination of less robust thallus lobes, scrobiculate surface, and apically dark isidia developing from dark, globose initials therefore appear to be diagnostic characters for L. isidiata. Lobariella corallophora agrees with $L$. isidiata in many aspects, but the isidia eventually become much branched with distinctly flattened base, and the medullary chemistry is of chemosyndrome A 1 .

\section{Lobariella nashii B. Moncada \& Lücking sp. nov.}

\section{MycoBank No.: MB801887}

Differing from Lobariella stenroosiae in the narrow, regularly and abundantly branched phyllidia.

Type: Mexico, Hidalgo, El Chico National Park, La Estanzuela, $20^{\circ} 11^{\prime} \mathrm{N}, 98^{\circ} 43^{\prime} \mathrm{W}, 2960 \mathrm{~m}, 26$ October 1998, Nash 42486 (H-holotype; ASU, F-isotypes).

(Fig. 9C-D)
Thallus growing on trunks and stems, up to $20 \mathrm{~cm}$ diam., rather closely attached; photobiont green (Dictyochloropsis). Individual lobes up to $10 \mathrm{~cm}$ long, with rounded to irregular apices and irregularly incised margins, $10-20 \mathrm{~mm}$ wide, irregularly branched, forming more or less irregular thallus rosettes. Upper surface bright green when hydrated, pale grey when dry and becoming grey-green in the herbarium, uneven; maculae present at the very lobe tips, indistinct, irregular, 0.03$0.05 \mathrm{~mm}$ diam., white, soon developing into pseudocyphellae; pseudocyphellae indistinct, moderately dense (3-7 per $\mathrm{mm}^{2}$ ), starting out as irregular, white spots but soon becoming elongate-linear, up to $1 \mathrm{~mm}$ long and $0 \cdot 1-0 \cdot 2 \mathrm{~mm}$ wide. Phyllidia abundant, developing individually and independent of the pseudocyphellae or ridges, upper side more or less concolorous with the thallus, at first cylindrical but soon becoming flattened and dorsiventral and much branched in a single plane (often as if combed), up to $2 \mathrm{~mm}$ long and individual branches up to $0.2 \mathrm{~mm}$ wide. Lower surface cream-coloured to pale yellowish brown, with a short, dense, cream-coloured to pale brown tomentum formed of up to 30 $\mu \mathrm{m}$ long hyphae composed of globose cells up to $5 \mu \mathrm{m}$ diam. and scattered, up to $1 \mathrm{~mm}$ long and $0.15 \mathrm{~mm}$ wide, pale brown to brown rhizines composed of strongly agglutinated, parallel hyphae; rhizines unbranched to sparsely branched at the tip and covered with tomentum towards the thallus centre. Upper cortex paraplectenchymatous, 20-30 $\mu \mathrm{m}$ thick with 3-5 $\mu \mathrm{m}$ thick epicortex, formed of 3-5 cell layers; algal layer 15-25 $\mu \mathrm{m}$ thick; medulla 80-130 $\mu \mathrm{m}$ thick; lower cortex paraplectenchymatous, $7-15 \mu \mathrm{m}$ thick, formed of 2(-3) cell layers.

Apothecia abundant, cup-shaped, up to 5 $\mathrm{mm}$ diam., with thick, strongly prominent, irregularly lobulate and isidiate-phyllidiate, grey to cream-coloured margins; lobules 1020 per apothecium, irregular with abundant phyllidia; disc concave, dark reddish brown. Excipulum composed of more or less parallel, partly branched hyphae with wide lumina resembling a paraplectenchyma, 50-80 $\mu \mathrm{m}$ wide, hyaline, finely inspersed and externally with a layer of dense, grey crystals, both inspersion and crystals dissolving in $\mathrm{KOH}$; 
hypothecium formed of densely intricate hyphae partially resembling a paraplectenchyma, 20-30 $\mu \mathrm{m}$ high, pale yellowish. Hymenium 110-130 $\mu \mathrm{m}$ high, clear, with yellow-orange, strongly conglutinated, $15-25 \mu \mathrm{m}$ high epithecium; asci narrowly clavate, 100-120 × 9$12 \mu \mathrm{m}$. Ascospores narrowly fusiform, 60$80 \times 3-4 \mu \mathrm{m}, 7$-septate, hyaline.

Pycnidia not observed.

Secondary chemistry. Chemosyndrome B: cortex with pseudocyphellarin A, $\mathrm{K}+$ yellow; medulla with Lobariella unidentified 3 (major), 4-O-methyl-gyrophoric acid (major), gyrophoric acid (minor), and Lobariella unidentified 2 (minor), $\mathrm{K}+$ emerald green to sordid yellow, $\mathrm{C}+$ weakly salmon-rose.

Ecology. Known from two well-developed collections, apparently widespread in the Neotropics and probably an upper montane rainforest species.

Notes. This conspicuous new species was originally identified as Lobariella subexornata, with sequences of the mtSSU (EU558804), nuLSU (EU558770), and ITS (AF524902) available in GenBank. However, it differs from the latter in multiple details: the medullary chemistry is of chemosyndrome B (vs A1), the dorsiventral phyllidia (flattened isidia in L. subexornata) are richly and regularly branched and the individual branches are narrower, and the apothecial margins produce abundant phyllidia. The most similar species appears to be L. stenroosiae, which differs in phyllidia morphology; both are also genetically distinct (Fig. 3). Lobariella nashii appears to be widespread but rare in the Neotropics, with collections from Mexico and Colombia.

Additional specimen examined. Colombia: Norte de Santander: Parque Nacional Natural Tamá, Sector Orocué, 2800 m, 2000, Moncada E Dávila 1112 b (UBCD).

\section{Lobariella olivascens B. Moncada \& Lücking sp. nov.}

\section{MycoBank No.: MB801888}

Differing from Lobariella crenulata in the thallus becoming olive-brown in the herbarium and the pseudocyphellae developing from distinct, large maculae at the lobe tips, as well as the chemosyndrome B medullary chemistry, with Lobariella unidentified 3 ( $\mathrm{K}+$ emerald green) instead of gyrophoric acid (C+ pink-red) as the major compound.

Type: Colombia, Risaralda, Pereira, Vereda La Suiza, Santuario de Fauna y Flora Otún Quimbaya, surroundings of visitor centre, $2300 \mathrm{~m}$, September 2003, Moncada E Dávila 2087 (UDBC-holotype; F-isotype).

(Fig. 9E \& F)

Thallus growing on trunks and stems, up to $12 \mathrm{~cm}$ diam., closely attached; photobiont green (Dictyochloropsis). Individual lobes up to $5 \mathrm{~cm}$ long, irregular with more or less truncate apices and irregularly incised margins, 7-15(-20) $\mathrm{mm}$ wide, irregularly branched, forming more or less circular thallus rosettes. Upper surface bright (dark) green when hydrated, dark grey when dry and becoming (dark) olive-green to olive-brown in the herbarium, even; maculae present at the very lobe tips, irregular, $0.1-0.3 \times 0.01-$ $0.03 \mathrm{~mm}$, white, strongly contrasting with the surrounding thallus surface, soon developing into pseudocyphellae; pseudocyphellae becoming elongate-linear up to $2 \mathrm{~mm}$ long and $0.1 \mathrm{~mm}$ wide and developing distinct linear cracks in the centre. Isidia absent. Lower surface cream-coloured to yellowish brown becoming dark brown, with a very short, dense, yellowish brown tomentum formed of up to $30 \mu \mathrm{m}$ long hyphae composed of globose cells up to $5 \mu \mathrm{m}$ diam. and discrete, up to $1.5 \mathrm{~mm}$ long and $0.15 \mathrm{~mm}$ wide, yellowish brown to dark brown rhizines composed of strongly agglutinated, parallel hyphae; rhizines unbranched to sparsely branched at the tip and covered with tomentum. Upper cortex paraplectenchymatous, $30-40 \mu \mathrm{m}$ thick with $4-5 \mu \mathrm{m}$ thick epicortex, formed of 4-6 cell layers; algal layer $15-25 \mu \mathrm{m}$ thick; medulla 100-150 $\mu \mathrm{m}$ thick; lower cortex paraplectenchymatous, $10-15 \mu \mathrm{m}$ thick, formed of 2-3 cell layers.

Apothecia abundant, cup-shaped, up to $5 \mathrm{~mm}$ diam., with thick, strongly prominent, lobulate, cream-coloured to yellowish brown margins; lobules 7-15 per apothecium, more or less regular with rounded tips; disc plane to concave, brown-black with reddish to purplish tinge. Excipulum composed of more or less parallel, partly branched hyphae with wide lumina resembling a paraplectenchyma, 30-60 $\mu \mathrm{m}$ wide, hyaline; hypothecium formed 
of densely intricate hyphae partially resembling a paraplectenchyma, 20-30 $\mu \mathrm{m}$ high, pale yellowish. Hymenium 100-120 $\mu \mathrm{m}$ high, clear, with yellow-orange, strongly conglutinated, 10-20 $\mu \mathrm{m}$ high epithecium; asci narrowly clavate, $100-120 \times 10-13 \mu \mathrm{m}$. Ascospores narrowly fusiform, $80-100 \times 5-6 \mu \mathrm{m}$, 7-septate, hyaline.

Pycnidia not observed.

Secondary chemistry. Chemosyndrome B: cortex with pseudocyphellarin A, K+ yellow; medulla with Lobariella unidentified 3 (major), 4-O-methyl-gyrophoric acid (major), gyrophoric acid (minor), and Lobariella unidentified 2 (minor), $\mathrm{K}+$ emerald green to sordid yellow, C- or + weakly salmon-rose.

Ecology. An upper montane rainforest species growing on branches and twigs of trees in semi-exposed situations.

Notes. This new species is similar to Lobariella crenulata but shows several differences, in addition to the medullary chemistry (chemosyndrome B vs A1b). The lobes are more irregular in outline and develop a dark, olive tinge in the herbarium; this was observed in all specimens originating from three distant localities and does not appear to be caused by specimen handling. Also, while L. crenulata develops minute, ecorticate pseudocyphellae from the lobe margins, in L. olivascens the pseudocyphellae start out as larger, corticate maculae strongly contrasting with the surrounding, darker thallus surface. Such large maculae are otherwise known only from L. pallidocrenulata, which is distinguished by its medullary chemistry and the usually larger lobes. The new species is known from Colombia and appears to be especially common in the north-east.

Additional specimens examined. Colombia: Cundinamarca: Choachí, Vereda El Verjón, Parque Ecológico Matarredonda, trail to andine forest, $4^{\circ} 34^{\prime} \mathrm{N}, 74^{\circ} 00^{\prime} \mathrm{W}$, 3000 m, 2010, Moncada 3164b (UDBC); Parque Nacional Natural Chingaza, 3100-3600 m, 1999, Moncada Eo Dávila 332 (UDBC). Norte de Santander: Parque Nacional Natural Tamá, Sector Orocué, 2800 m, 2000, Moncada E Dávila 897b (UDBC); ibid., 2000, Moncada \& Dávila 1185, 1187, 1212, 1263 (UDBC).

\section{Lobariella pallida (Hook.) B. Moncada \& Lücking}

in Lumbsch et al., Phytotaxa 18: 82 (2011)._Sticta pallida Hook. in Kunth, Syn. Plant. Aequinoct. Orb. Novi 1: 28 (1822).-Lobaria pallida (Hook.) Trevis., Lichenotheca Veneta: no. 75 (1869).- Durietzia pallida (Hook.) Yoshim. in Marcelli \& Ahti, Recollecting Edvard August Vainio: 91 (1998); type: Ecuador, Hooker s. n. (BMholotype, not seen).

Parmelia fulvella Taylor in Hook., London F. Bot. 6: 168 (1847); type: Peru, Mathews s. n. (FH-holotype!).

(Fig. 10A-C)

Notes. For a detailed description of this species, see Yoshimura (1984) and Yoshimura \& Arvidsson (1994). Lobariella pallida is characterized by the combination of a very loosely attached thallus (with the periphery distant from the substratum) and a hypermaculate lobe surface, especially at the lobe margins: the maculae form a continous, dense network separating the darker areas containing photobiont cells and only in old thallus parts may develop into cracks, but not genuine pseudocyphellae. At the lobe margins the maculae become confluent to form a more or less algal-free zone. The term 'hypermaculate' was recently coined by Spielmann (2009) to describe this type of confluent maculae in Parmeliaceae (Parmotrema), but has also been used in entomology (Remane \& Holzinger 1995). Besides L. crenulata and L. soredians, L. pallida appears to be the only species with a regular presence of methyl-gyrophorate in addition to gyrophoric acid and pseudocyphellarin A (chemosyndrome A1a). Two further, related species with a green photobiont and apothecia that resemble $L$. pallida are now distinguished: L. pallidocrenulata forms discrete, distinct, slightly elevated maculae at the lobe tips which soon develop into pseudocyphellae, whereas $L$. reticulata has a reticulate network of maculae but is not hypermaculate, and the apothecial margins appear crisp due to numerous, small, irregular lobules. Both are phylogenetically distinct (Fig. 3). Other species with similar medullary chemistry and apothecia produce distinct cyphellae.

Material resembling Lobariella pallida but with a finely scrobiculate surface was found 

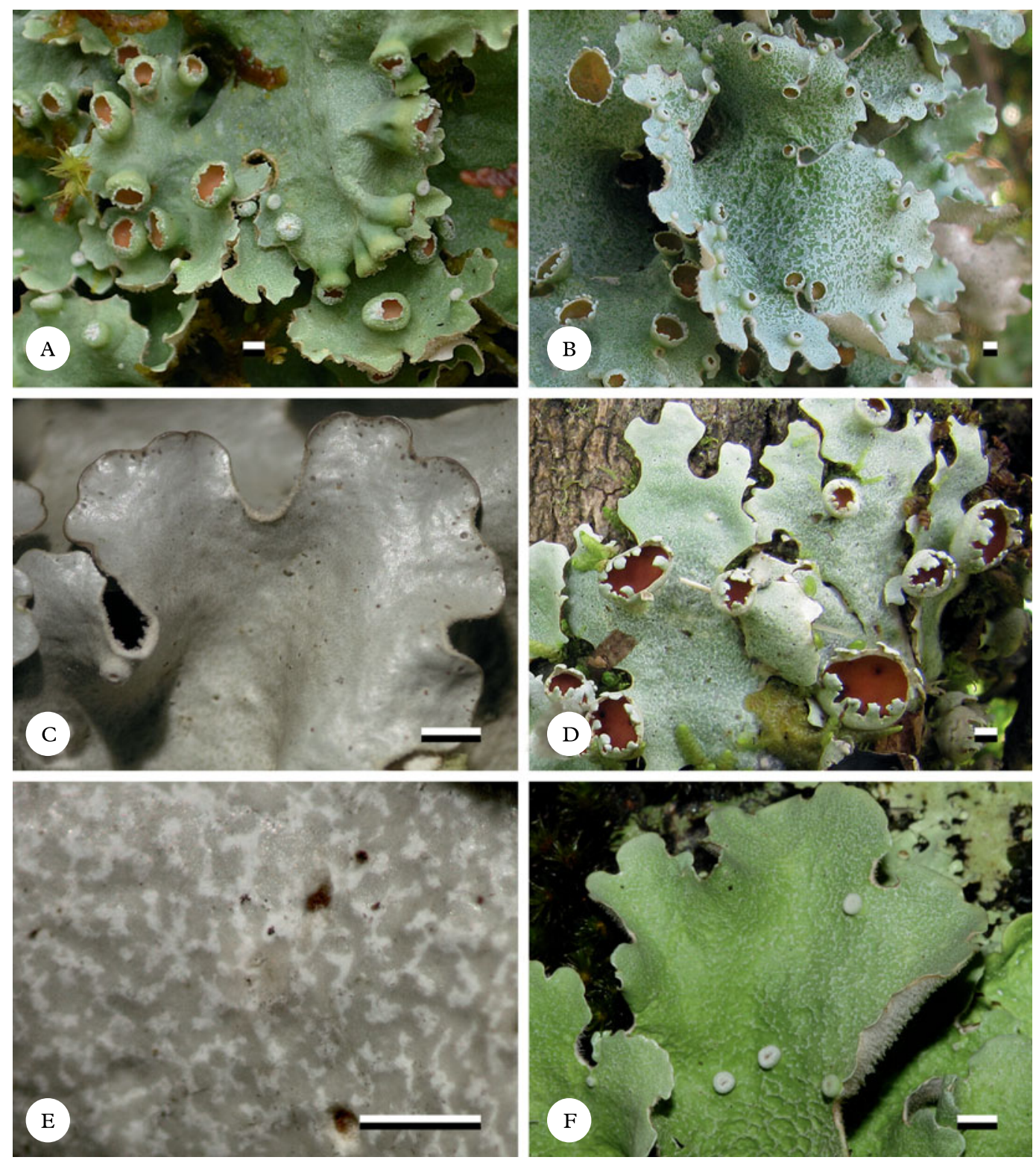

FIg. 10. Habit of Lobariella species. A-C, L. pallida (A, field image from Brazil; B, Lücking 34056; C, Moncada 4779), showing upper side with hypermaculae towards the margins (A, B) and close-up of hypermaculate margin (C); D \& E, L. pallidocrenulata (D, Lücking 33354; E, holotype), showing upper side with distinct maculae and pseudocyphellae (D) and marginal, discrete maculae enlarged (E); F, L. aff. pallidocrenulata (field image from Brazil by Adriano Spielmann), showing upper side with distinct, discrete maculae and central part becoming scrobiculate. Scale $=1 \mathrm{~mm}$. In colour online.

in Colombia (Boyacá: Municipio El Cocuy, Parque Nacional Natural El Cocuy, Alto de la Cueva, 3800 m, 21 April 2011, Fonseca $\mathcal{E}$
Martinez 41, UDBC). Unfortunately the material is too scanty to evaluate its taxonomic status. 
Lobariella pallida is by far the most common species of the genus and found abundantly on twigs and thin stems of shrubs and treelets in the páramo region. It usually grows in between other lichens and bryophytes but enjoys a competitive advantage due to its very loosely attached thallus which does not require much surface space. It is one of the most characteristic páramo lichens.

Specimens examined. Costa Rica: San fosé: Los Santos Forest Reserve, Cerro de la Muerte Biological Station, $83^{\circ} 45^{\prime} \mathrm{W}, 9^{\circ} 34^{\prime} \mathrm{N}, 3100-3400 \mathrm{~m}$, upper montane cloud forest, 2002, Lücking 15372 (F), 15404a (F, INB), 15404b (F), 15564 (F), 15566 (F, INB); ibid., 2012, Moncada 5684 (F, UDBC)._Colombia: Cauca: Parque Nacional Natural Puracé, 3220 m, 2000, Moncada \& Dávila 500 (UDBC). Cundinamarca: Choachí, Vereda El Verión, Parque Ecológico Matarredonda, trail to andine forest, $4^{\circ} 34^{\prime} \mathrm{N}, 74^{\circ} 00^{\prime} \mathrm{W}, 3000 \mathrm{~m}, 2007$, Carreño et al. 29 (UDBC); Parque Nacional Natural Chingaza, 3100-3600 m, 1999, Moncada E Dávila 265, 300 (UDBC); ibid., 2003, Moncada \& Dávila 1454, 1514 (UDBC); ibid., 2004, Moncada E Dávila 2161, 2171, 2239 (UDBC); Parque Natural Chicaque, 2200-2700 m, 1996, Moncada E Dávila 208 (UDBC); Santa Fé, 2009, Rodríguez \& Zárate 48 (UDBC); Vereda Marilandia, $2400 \mathrm{~m}, 2011$, Moncada 4774, 4779, 4780, 4781 (UDBC); Zona de Amortiguación (Mundo Nuevo), Parque Nacional Natural Chingaza, 2900-3100 m, 2011, Moncada 4905 (UDBC); Municipio de Villapinzón, Páramo de Guacheneque, Nacimiento del Río Bogotá, 3400 m, 2012, Moncada 5489, 5492, 5498 (F, UDBC). Norte de Santander: Parque Nacional Natural Tamá, Sector Orocué, 2800 m, 2000, Moncada \& Dávila 897a (UDBC); ibid., 2000, Moncada \& Dávila 1079 (UDBC); ibid., 2000, Moncada \& Dávila 1211, 1230, 1246, 1249, 1254, 1257, 1266 (UDBC). Risaralda: Pereira, Vereda La Suiza, Santuario de Fauna y Flora Otún Quimbaya, surroundings of visitor centre, $2300 \mathrm{~m}, 2003$, Moncada E Dávila 2106 (UDBC).

\section{Lobariella pallidocrenulata B. Moncada \& Lücking sp. nov.}

\section{MycoBank No.: MB801889}

Differing from Lobariella pallida in the discrete and conspicuous marginal maculae developing into pseudocyphellae.

Type: Colombia, Cundinamarca, Choachí, Vereda El Verjón, Parque Ecológico Matarredonda, trail to andine forest, $4^{\circ} 34^{\prime} \mathrm{N}, 74^{\circ} 00^{\prime} \mathrm{W}, 3000 \mathrm{~m}, 2010$, Moncada $3164 \mathrm{a}$ (UDBC-holotype).

(Fig. 10D \& E)

Thallus growing on thin trunks, stems, and branches, up to $10 \mathrm{~cm}$ diam., loosely to very loosely attached; photobiont green (Dictyochloropsis). Individual lobes up to $4 \mathrm{~cm}$ long, irregular with more or less truncate apices and irregularly to dichotomously incised margins, $10-20 \mathrm{~mm}$ wide, irregularly branched, forming more or less circular thallus rosettes. Upper surface pale green when hydrated, pale grey when dry and remaining pale grey or becoming pale yellowish grey in the herbarium, even at the lobe tips but becoming shallowly ridged towards the centre; maculae present at the very lobe tips, irregular, $0 \cdot 1-0.3 \times 0.01-$ $0.03 \mathrm{~mm}$, white, weakly contrasting with the surrounding thallus surface but often slightly elevated over the thallus level, soon developing into immersed to erumpent pseudocyphellae; pseudocyphellae developing from marginal maculae, becoming elongate-linear and forming shallow ridges, up to $1 \mathrm{~mm}$ long and $0.1 \mathrm{~mm}$ wide and developing distinct linear cracks in the centre. Isidia absent. Lower surface cream-coloured to pale yellowish brown, with a very short, dense, creamcoloured to pale yellowish brown tomentum formed of up to $30 \mu \mathrm{m}$ long hyphae composed of globose cells up to $5 \mu \mathrm{m}$ diam. and dense but discrete, up to $1.5 \mathrm{~mm}$ long and $0.15 \mathrm{~mm}$ wide, white to pale yellowish brown rhizines composed of strongly agglutinated, parallel hyphae; rhizines unbranched to occasionally branched at the tip and covered with tomentum at least two thirds up to the tip. Upper cortex paraplectenchymatous, 30$40 \mu \mathrm{m}$ thick with $4-5 \mu \mathrm{m}$ thick epicortex, formed of 4-6 cell layers; algal layer 15-25 $\mu \mathrm{m}$ thick; medulla 100-150 $\mu \mathrm{m}$ thick; lower cortex paraplectenchymatous, $10-15 \mu \mathrm{m}$ thick, formed of 2-3 cell layers.

Apothecia abundant, cup-shaped, up to $5 \mathrm{~mm}$ diam., with thick, strongly prominent, lobulate, pale grey to cream-coloured margins; lobules 7-15 per apothecium, more or less regular with rounded or bifurcate tips; disc concave, orange-brown. Excipulum composed of more or less parallel, partly branched hyphae with wide lumina resembling a paraplectenchyma, 40-60 $\mu \mathrm{m}$ wide, hyaline; hypothecium formed of densely intricate hyphae partially resembling a paraplectenchyma, 20-30 $\mu \mathrm{m}$ high, pale yellowish. Hymenium 120-140 $\mu \mathrm{m}$ high, clear, with 
yellow-orange, strongly conglutinated, 15-25 $\mu \mathrm{m}$ high epithecium; asci narrowly clavate, $110-130 \times 10-14 \mu \mathrm{m}$. Ascospores narrowly fusiform, $70-100 \times 4.5-5.5 \mu \mathrm{m}, 7$-septate, hyaline.

Pycnidia not observed.

Secondary chemistry. Chemosyndrome Alb: cortex with pseudocyphellarin A, K+ yellow; medulla with gyrophoric acid (major) and Lobariella unidentified 1 (major), $\mathrm{K}-, \mathrm{C}+$ pink-red.

Ecology. Like Lobariella pallida, L. pallidocrenulata is principally a páramo lichen found on treelets and shrubs in more or less exposed situations. Both species often grow side by side and only upon closer examination are recognized as distinct. Lobariella pallidocrenulata has a more appressed thallus and is more commonly found on the stems of small trees, but this difference has not been quantified.

Notes. This new species is very similar to Lobariella pallida and easily mistaken for that species in the field, due to the often very loosely attached thallus with similar colour. However, in contrast to Lobariella pallida, which has a marginally hypermaculate surface and lacks pseudocyphellae, the maculae in L. pallidocrenulata are large and discrete and soon develop into pseudocyphellae. This morphology is identical to that found in L. olivascens, which differs in the more closely attached thallus becoming olive in the herbarium, and also in its medullary chemistry (chemosyndrome B vs A1b). Molecular data show that L. pallidocrenulata is genetically distinct from L. pallida, although found in the same clade (Fig. 3). The species is common in Colombia and has also been found in Costa Rica.

A probably undescribed species is known only from a field image from Brazil (Fig. $10 \mathrm{~F}$ ) taken by A. Spielmann (pers. comm. 2012). It has the same kind of maculae as Lobariella pallidocrenulata but does not appear to form pseudocyphellae; in addition, it becomes scrobiculate towards the thallus centre.
Additional specimens examined. Costa Rica: Cartago: Irazú National Park, 3400 m, 2002, Lücking 15489 (F). San fosé: Los Santos Forest Reserve, Cerro de la Muerte Biological Station, $83^{\circ} 45^{\prime} \mathrm{W}, 9^{\circ} 34^{\prime} \mathrm{N}, 3100-3400 \mathrm{~m}$, upper montane cloud forest, 2012, Moncada 5659, 5703 (F, UDBC)._Colombia: Cauca: Parque Nacional Natural Puracé, 3200-3500 m, 2011, Díaz E Soto L10 (F, UDBC). Cundinamarca: Páramo de Guasca, 2011, Moncada 4709 (UDBC); Choachí, Vereda El Verjón, Parque Ecológico Matarredonda, trail to andine forest, $4^{\circ} 34^{\prime} \mathrm{N}, 74^{\circ} 00^{\prime} \mathrm{W}, 3000 \mathrm{~m}, 2007$, Carreño et al. 23 (UDBC); Parque Nacional Natural Chingaza, 3100-3600 m, 1999, Moncada et al. 62 (UDBC); ibid., 2002, Moncada \& Dávila 1432 (UDBC); ibid., 2003, Moncada \& Dávila 1548 (UDBC); Parque Nacional Natural Sumapáz, 3500-3700 m, 2004, Moncada $\mathcal{E}$ Dávila 2160, 2165, 2172, 2200, 2247, 2337 (UDBC); ibid., 2008, Beltrán-A. et al. 24 (UDBC); ibid., 2010, Moncada 4078, 4099 (UDBC); Santa Fé, 2009, Rodriguez \& Zárate 27, 37 (UDBC); Vereda El Verjón, 2007, Malaver et al. 153 (UDBC); Municipio de Villapinzón, Páramo de Guacheneque, Nacimiento del Río Bogotá, 3400 m, 2012, Moncada 5499 (F, UDBC). Norte de Santander: Parque Nacional Natural Tamá, Sector Orocué, 2800 m, 2000, Moncada E Dávila 1073 (UDBC); ibid., 2000, Moncada E Dávila 1232, 1250 (UDBC). Tolima: Parque Nacional Natural Los Nevados, 2008, Ardila 264 (UDBC).

\section{Lobariella papillifera B. Moncada \& Lücking sp. nov.}

\section{MycoBank No.: MB801890}

Differing from Lobariella subexornata in the short isidia growing predominantly from pseudocyphellae and having a papillose surface, as well as in the chemosyndrome B medullary chemistry, with Lobariella unidentified 3 $(\mathrm{K}+$ emerald green) instead of gyrophoric acid (C+ pink-red) as major compound.

Type: Costa Rica, Puntarenas, Parque Internacional La Amistad, Estación Altamira, $83^{\circ} 00^{\prime} \mathrm{W}, 9^{\circ} 02^{\prime} \mathrm{N}$, 1600-1800 m, 1 July 2002, Lücking 15248a (F-holotype).

\section{(Fig. 11A \& B)}

Thallus growing on trunks and stems, up to $10 \mathrm{~cm}$ diam., closely attached; photobiont green (Dictyochloropsis). Individual lobes up to $5 \mathrm{~cm}$ long, irregular with more or less truncate apices and dichotomously incised margins (Parmelia-like), 5-10 mm wide, irregularly branched, forming more or less irregular thallus rosettes. Upper surface bright green when hydrated, pale grey when dry and becoming pale yellowish brown in the herbarium, shallowly to distinctly ridged especially towards the centre; maculae absent; 

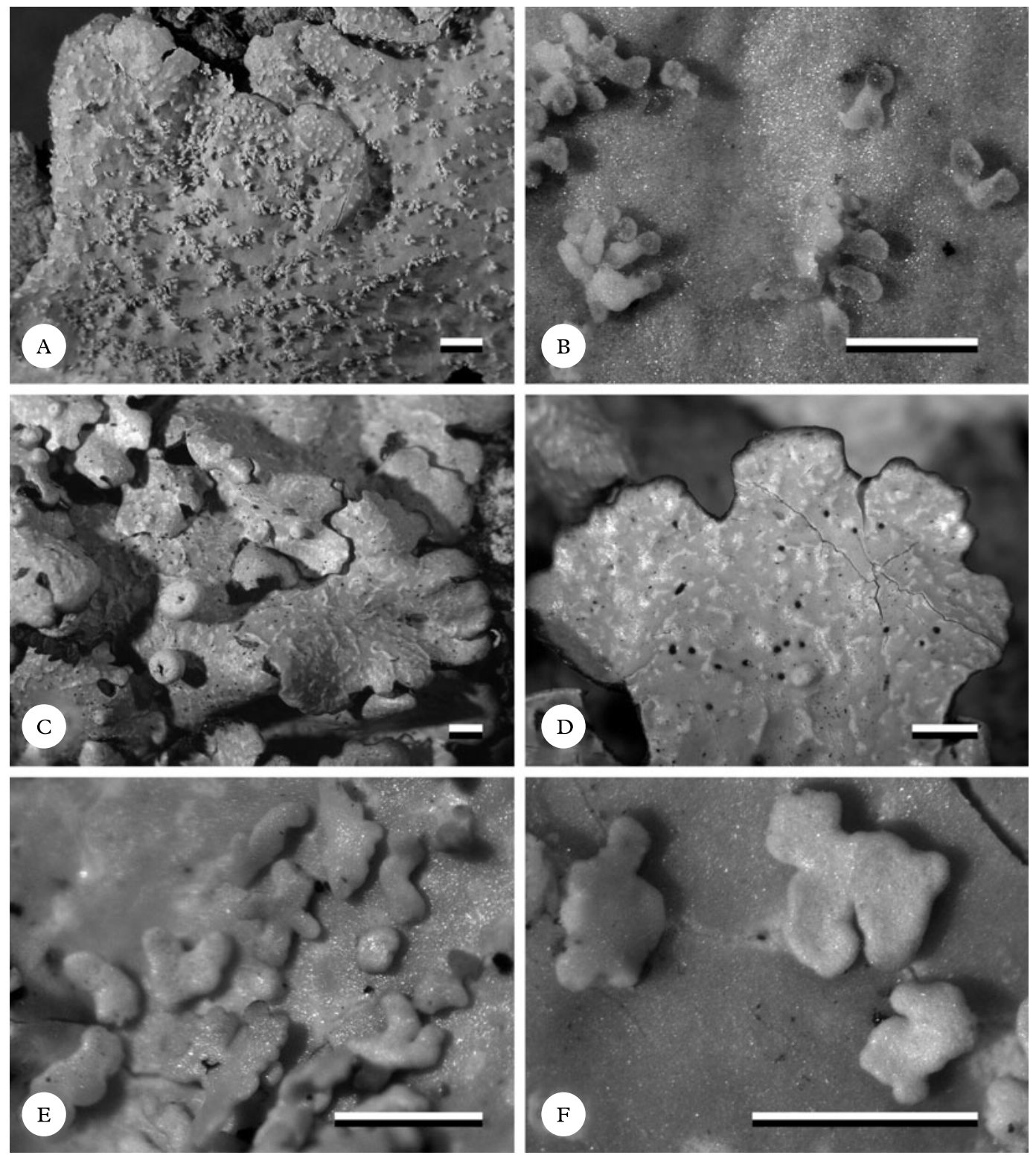

FIG. 11. Habit of Lobariella species. A \& B, L. papillifera (holotype), showing upper side with isidia (A) and isidia enlarged to show surface texture (B); C \& D, L. parmelioides (holotype), showing upper side with maculae and pseudocyphellae; E \& F, L. peltata (holotype), showing peltate phyllidia. Scale $=1 \mathrm{~mm}$.

pseudocyphellae present from the lobe tips, starting out as irregular, white lines $0.10 \times 0.05$ $\mathrm{mm}$ diam., becoming elongate-linear up to $1 \mathrm{~mm}$ long and $0 \cdot 1 \mathrm{~mm}$ wide. Isidia abundant, developing in groups on the pseu- docyphellae or ridges, becoming slightly flattened, concolorous with the thallus, remaining short and mostly unbranched, up to $0.03 \mathrm{~mm}$ high, appearing minutely pubescent (lens magnification); in microscopic 
section, the cortical cells have protruding papillae. Lower surface pale yellowish brown, with a short, dense, pale yellowish brown tomentum formed of up to $30 \mu \mathrm{m}$ long hyphae composed of globose cells up to $5 \mu \mathrm{m}$ diam. and discrete, up to $1 \mathrm{~mm}$ long and $0.15 \mathrm{~mm}$ wide, pale rhizines composed of strongly agglutinated, parallel hyphae; rhizines unbranched to sparsely branched at the tip and covered with tomentum towards the thallus centre. Upper cortex paraplectenchymatous, 20-30 $\mu \mathrm{m}$ thick with 3-5 $\mu \mathrm{m}$ thick epicortex, formed of 3-5 cell layers; algal layer 15-25 $\mu \mathrm{m}$ thick; medulla 80-130 $\mu \mathrm{m}$ thick; lower cortex paraplectenchymatous, $7-15 \mu \mathrm{m}$ thick, formed of 2(-3) cell layers.

Apothecia and pycnidia not observed.

Secondary chemistry. Chemosyndrome B: cortex with traces of pseudocyphellarin A, $\mathrm{K}+$ yellow; medulla with Lobariella unidentified 3 (major), 4-O-methyl-gyrophoric acid (major), gyrophoric acid (trace), and $\mathrm{Lo}^{-}$ bariella unidentified 2 (trace), $\mathrm{K}+$ emerald green, C-.

Ecology. Known only from the type locality and apparently a lower montane to montane rainforest lichen.

Notes. This new species resembles Lobariella subexornata in general morphology and the more or less flattened isidia, but the isidia are thicker, shorter, more irregular in shape and have a minutely papillate surface. The chemistry is shared with several other species in this group, but the papillate isidia are unique, which is why we are confident in describing this new species even if we were unable to extract DNA from the only available specimen.

\section{Lobariella parmelioides B. Moncada \& Lücking sp. nov.}

\section{MycoBank No.: MB801891}

Differing from Lobariella crenulata in the regularly truncate, Parmelia-like lobes and the apothecia having fewer marginal lobules (7-15 vs $15-30)$.

Type: Colombia, Cundinamarca, Choachí, Vereda El Verjón, Parque Ecológico Matarredonda, trail to andine forest, $4^{\circ} 34^{\prime} \mathrm{N}, 74^{\circ} 00^{\prime} \mathrm{W}, 3000 \mathrm{~m}, 10$ March 2012, Moncada 5355 (UDBC-holotype; F-isotype).

\section{(Fig. 11C \& D)}

Thallus growing on thin trunks, stems, and branches, up to $8 \mathrm{~cm}$ diam., loosely attached; photobiont green (Dictyochloropsis). Individual lobes up to $4 \mathrm{~cm}$ long, irregular with more or less truncate apices and irregularly to dichotomously incised margins, $5-10 \mathrm{~mm}$ wide, irregularly to dichotomously branched, forming more or less circular thallus rosettes. Upper surface pale green when hydrated, pale grey when dry and remaining pale grey or becoming pale yellowish grey in the herbarium, with a narrow dark brown line along the margin, even at the lobe tips but becoming shallowly ridged towards the centre; maculae absent or present at the very lobe tips, irregular, very soon developing into pseudocyphellae; pseudocyphellae becoming elongate-linear up to $2 \mathrm{~mm}$ long and $0 \cdot 1$ $\mathrm{mm}$ wide and developing distinct linear cracks towards the centre. Isidia absent. Lower surface cream-coloured to pale yellowish brown, with a very short, dense, creamcoloured to pale yellowish brown tomentum formed of up to $25 \mu \mathrm{m}$ long hyphae composed of globose cells up to $5 \mu \mathrm{m}$ diam. and dense but discrete, up to $1.5 \mathrm{~mm}$ long and $0.15 \mathrm{~mm}$ wide, white to pale yellowish brown rhizines composed of strongly agglutinated, parallel hyphae; rhizines unbranched to occasionally branched at the tip or becoming spongiose towards the thallus centre, covered with tomentum at least two thirds up to the tip. Upper cortex paraplectenchymatous, $25-35 \mu \mathrm{m}$ thick with 3-4 $\mu \mathrm{m}$ thick epicortex, formed of 3-5 cell layers; algal layer 15-25 $\mu \mathrm{m}$ thick; medulla 100-120 $\mu \mathrm{m}$ thick; lower cortex paraplectenchymatous, $10-15 \mu \mathrm{m}$ thick, formed of 2-3 cell layers.

Apothecia abundant, cup-shaped, up to $5 \mathrm{~mm}$ diam., with thick, strongly prominent, lobulate, pale grey to cream-coloured margins; lobules 10-20 per apothecium, more or less regular with rounded or bifurcate tips; disc concave, orange-brown. Excipulum composed of more or less parallel, partly branched hyphae with wide lumina resembling a paraplectenchyma, 30-50 $\mu \mathrm{m}$ wide, hyaline; hypothecium formed of densely intricate hyphae partially resembling a paraplec- 
tenchyma, 15-25 $\mu \mathrm{m}$ high, pale yellowish. Hymenium 100-110 $\mu \mathrm{m}$ high, clear, with yellow-orange, strongly conglutinated, 10$20 \mu \mathrm{m}$ high epithecium; asci narrowly clavate, 90-105 $\times 9-12 \mu \mathrm{m}$. Ascospores narrowly fusiform, $50-75 \times 3.5-4.5 \mu \mathrm{m}, 7$-septate, hyaline.

Pycnidia not observed.

Secondary chemistry. Chemosyndrome A1b: cortex with pseudocyphellarin A, K+ yellow; medulla with gyrophoric acid (major) and Lobariella unidentified 1 (major), $\mathrm{K}-, \mathrm{C}+$ pink-red.

Ecology. Lobariella parmelioides appears to be a páramo lichen, but with a much more restricted distribution than the common and widespread L. pallida. At the type locality, the species appears to be rather abundant, but it has not been found at most of the other páramos studied.

Notes. This new species at first glance resembles a Parmelia in colour, branching pattern and lobe configuration, and in the distinct pseudocyphellae. It is most similar to Lobariella crenulata, but the lobes are regularly truncate (irregular in L. crenulata) and the apothecia have fewer marginal lobules (7-15 vs $15-30)$. Both are phylogenetically distinct and can be considered to be a nearly cryptic species. Lobariella pallida, which appears to be sister to L. parmelioides (Fig. 3), differs in its much broader lobes with hypermaculate margins and lack of pseudocyphellae, and L. pallidocrenulata also has much broader lobes. Another similar species is L. olivascens, which turns dark olive in the herbarium with irregular, upturned lobules, and has a different medullary chemistry.

Additional specimens examined. Colombia: Cundinamarca: Choachí, Vereda El Verjón, 2012, Moncada 5351, 5356, 5357, 5358 (F, UDBC); Municipio de Villapinzón, Páramo de Guacheneque, Nacimiento del Río Bogotá, 3400 m, 2012, Moncada 5477 (F, UDBC).

\section{Lobariella peltata B. Moncada \& Lücking sp. nov.}

\section{MycoBank No.: MB801892}

Differing from Lobariella subexornata in the peltate isidia and dark lower tomentum, and the chemosyndrome A2 medullary chemistry with lecanoric instead of gyrophoric acid as major compound.
Type: Colombia, Cundinamarca, Parque Nacional Natural Chingaza, 3100-3600 m, 13 May 2003, Moncada \& Dávila 1530 (UDBC-holotype).

(Fig. 11E \& F)

Thallus growing on trunks and stems, up to $10 \mathrm{~cm}$ diam., rather loosely attached; photobiont green (Dictyochloropsis). Individual lobes up to $5 \mathrm{~cm}$ long, with rounded to irregular apices and irregularly incised margins, 3-7 mm wide, irregularly branched, forming more or less irregular thallus rosettes. Upper surface bright green when hydrated, pale grey when dry and becoming pale yellowish brown in the herbarium, more or less even; maculae absent; pseudocyphellae present from the lobe tips, moderately dense (1-3 per $\mathrm{mm}^{2}$ ), starting out as irregular, white spots but soon becoming elongate-linear, up to $1 \mathrm{~mm}$ long and $0 \cdot 1-0.2 \mathrm{~mm}$ wide and developing distinct linear cracks towards the centre. Phyllidia abundant, developing in groups, flattened from the beginning and becoming irregularly branched, peltate (i.e. branching from a central umbilicus but often asymmetrical), of the same colour as the thallus, up to $1 \mathrm{~mm}$ diam. and individual branches $0.1-0.3 \mathrm{~mm}$ wide. Lower surface pale yellowish brown to brown, with a short, dense, yellow-brown tomentum formed of up to $30 \mu \mathrm{m}$ long hyphae composed of globose cells up to $5 \mu \mathrm{m}$ diam. and discrete, up to $1 \mathrm{~mm}$ long and $0.15 \mathrm{~mm}$ wide, dark brown to blackened rhizines composed of strongly agglutinated, parallel hyphae; rhizines unbranched to sparsely branched at the tip and covered with tomentum towards the thallus centre. Upper cortex paraplectenchymatous, $20-25 \mu \mathrm{m}$ thick with $3-5 \mu \mathrm{m}$ thick epicortex, formed of 3-4 cell layers; algal layer 15-25 $\mu \mathrm{m}$ thick; medulla 80-100 $\mu \mathrm{m}$ thick; lower cortex paraplectenchymatous, $7-$ $15 \mu \mathrm{m}$ thick, formed of $2(-3)$ cell layers.

Apothecia not observed.

Pycnidia not observed.

Secondary chemistry. Chemosyndrome A2: cortex with pseudocyphellarin A, K+ yellow; medulla with lecanoric acid (major), methyllecanorate (trace), and Lobariella unidentified 1 (major), $\mathrm{K}-$ or $\mathrm{K}+$ faintly yellowbrown, $\mathrm{C}+$ red. 
Ecology. Known only from the type locality in the transitional zone between subandine cloud forest and páramo.

Notes. This species is described here formally although it is known only from a single collection. The morphological and chemical characteristics are unique: no other species in the genus has regularly peltate phyllidia (although the phyllidia in L. stenroosiae might become somewhat peltate), and the combination of lecanoric acid as the main medullary substance and a dark lower tomentum is otherwise unknown in Lobariella. Most similar is L. subexornata, in which the isidia are flattened but not peltate, gyrophoric acid is the main medullary substance, and the lower tomentum is not as dark as in L. peltata. A species with similar chemistry and dark lower tomentum is L. ecorticata, which, however, has erect phyllidia with ecorticate underside.

\section{Lobariella pseudocrenulata B. Moncada \& Lücking sp. nov.}

\section{MycoBank No.: MB801893}

Differing from Lobariella crenulata in the more loosely attached thallus and the medullary chemistry, containing Lobariella unidentified 3 ( $\mathrm{K}+$ emerald green) instead of gyrophoric acid ( $\mathrm{C}+$ pink-red) as the major compound.

Type: Colombia, Casanare, Chameza, 600-800 m, 24-31 January 2012, Vargas $\mathcal{E}$ Herrera 309b (UDBCholotype; F-isotype).

(Fig. 12A \& B)

Thallus growing on trunks and stems, up to $10 \mathrm{~cm}$ diam., more or less loosely attached; photobiont green (Dictyochloropsis). Individual lobes up to $5 \mathrm{~cm}$ long, with dichotomously branched, truncate apices and entire margins (Parmelia-like), 5-10 mm wide, regularly branched, forming more or less rounded thallus rosettes. Upper surface grey-green when hydrated, pale grey when dry and becoming pale yellowish brown in the herbarium, smooth to slightly uneven towards the centre; maculae present at the lobe tips, irregular, $0 \cdot 1-$ $0.3 \times 0.01-0.03 \mathrm{~mm}$, white, contrasting with the surrounding thallus surface and often slightly elevated over the thallus level, soon developing into pseudocyphellae; pseudo- cyphellae becoming elongate-linear up to $2 \mathrm{~mm}$ long and $0.2 \mathrm{~mm}$ wide towards the centre. Isidia absent. Lower surface creamcoloured to pale yellowish brown, with a short, dense, cream-coloured to pale brown tomentum formed of up to $30 \mu \mathrm{m}$ long hyphae composed of globose cells up to $5 \mu \mathrm{m}$ diam. and discrete, up to $1 \mathrm{~mm}$ long and $0.1 \mathrm{~mm}$ wide, cream-coloured to greybrown rhizines composed of strongly agglutinated, parallel hyphae; rhizines unbranched to sparsely branched at the tip and covered with tomentum towards the thallus centre. Upper cortex paraplectenchymatous, 20-30 $\mu \mathrm{m}$ thick with 3-5 $\mu \mathrm{m}$ thick epicortex, formed of 3-5 cell layers; algal layer 15-25 $\mu \mathrm{m}$ thick; medulla 80-140 $\mu \mathrm{m}$ thick; lower cortex paraplectenchymatous, $7-15 \mu \mathrm{m}$ thick, formed of 2(-3) cell layers.

Apothecia abundant, cup-shaped, up to $5 \mathrm{~mm}$ diam., with thick, strongly prominent, lobulate, grey to cream-coloured margins; lobules 7-15 per apothecium, more or less regular with rounded or rarely bifurcate tips; disc concave, orange-brown. Excipulum composed of more or less parallel, partly branched hyphae with wide lumina resembling a paraplectenchyma, 30-50 $\mu \mathrm{m}$ wide, hyaline; hypothecium formed of densely intricate hyphae partially resembling a paraplectenchyma, 15$25 \mu \mathrm{m}$ high, pale yellowish. Hymenium 100$120 \mu \mathrm{m}$ high, clear, with yellow-orange, strongly conglutinated, $10-20 \mu \mathrm{m}$ high epithecium; asci narrowly clavate, 95-110 × 9$13 \mu \mathrm{m}$. Ascospores narrowly fusiform, 60$75 \times 3-4 \mu \mathrm{m}, 7$-septate, hyaline.

Pycnidia not observed.

Secondary chemistry. Chemosyndrome B: cortex with traces of pseudocyphellarin A, $\mathrm{K}+$ yellow; medulla with Lobariella unidentified 3 (major), 4-O-methyl-gyrophoric acid (major), gyrophoric acid (trace), and Lobariella unidentified 2 (minor), $\mathrm{K}+$ emerald green to sordid yellow, C- or + weakly salmon-rose.

Ecology. Known only from the type locality in a lower montane rainforest.

Notes. This is another species that shares gross morphology with Lobariella crenulata 

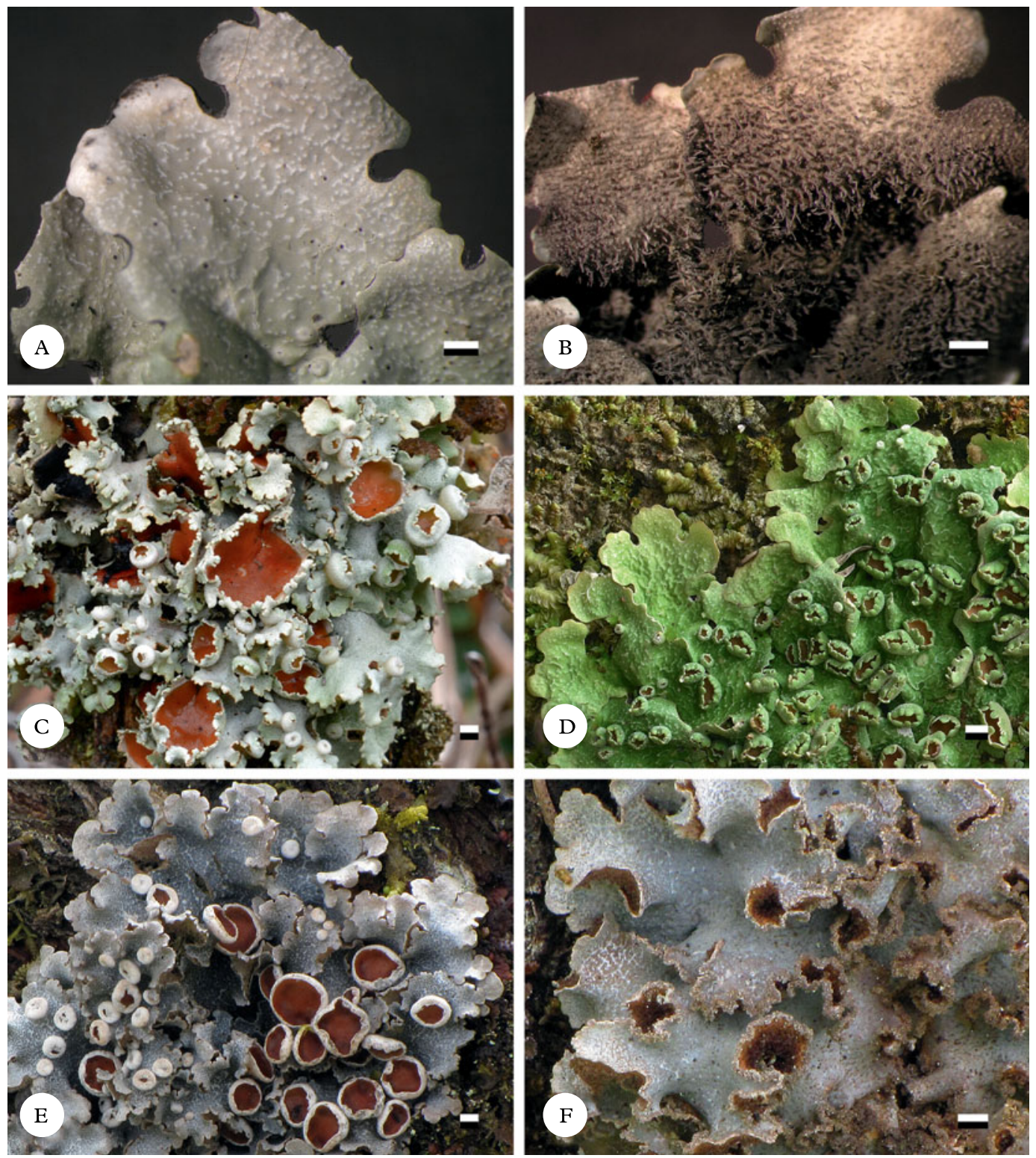

FIG. 12. Habit of Lobariella species. A \& B, L. pseudocrenulata (holotype), showing upper (A) and lower sides (B); C, L. reticulata (Lücking s. n.), showing upper side with crisp apothecial margins; D, L. rugulosa (holotype), showing upper side with rugulose surface; E, L. sipmanii (paratype), showing upper side with smooth apothecial margins; $\mathrm{F}$, L. soredians (holotype), showing upper side with marginal soralia. Scale $=1 \mathrm{~mm}$. In colour online.

but belongs in the group with chemosyndrome B medullary chemistry. Among the four species in this group with apothecia, including also $L$. angustata, L. olivascens, and $L$. subcrenulata, it is distinguished by the initial formation of marginal maculae that develop into pseudocyphellae. This character is shared in this group only by L. olivascens, 
which has broader, more irregular and ascending lobes that turn olive in the herbarium. Lobariella pallidocrenulata is externally similar but has a different medullary chemistry (chemosyndrome A1b vs B) and larger thalli with broader lobes $(10-20 \mathrm{~mm}$ vs 5$10 \mathrm{~mm}$ ). Phylogenetically, L. pseudocrenulata is sister to the isidiate L. auriculata (Fig. 3).

\section{Lobariella reticulata B. Moncada \& Lücking sp. nov.}

\section{MycoBank No.: MB801894}

Differing from Lobariella pallida in the more distinctly reticulate maculae and the crisp apothecial margins composed of numerous, irregular, small lobules.

Type: Colombia, Cundinamarca, La Calera, Mundo Nuevo, Zona de Amortiguación, 2900-3100 m, 7 November 2011, Moncada 4982 (UDBC-holotype).

(Fig. 12C)

Thallus growing on thin trunks, stems, and branches, up to $8 \mathrm{~cm}$ diam., loosely attached; photobiont green (Dictyochloropsis). Individual lobes up to $4 \mathrm{~cm}$ long, irregular with incised apices and irregularly incised margins, 5$10 \mathrm{~mm}$ wide, irregularly branched, forming more or less circular to irregular thallus rosettes. Upper surface pale green when hydrated, pale grey when dry and remaining pale grey or becoming pale yellowish grey in the herbarium, even; maculae dense from the margin, linear, forming a reticulate network, white, weakly contrasting with the surrounding thallus surface; pseudocyphellae absent but thallus often forming reticulate cracks towards the centre. Isidia absent. Lower surface creamcoloured to pale yellowish brown, with a very short, dense, cream-coloured to pale yellowish brown tomentum formed of up to $30 \mu \mathrm{m}$ long hyphae composed of globose cells up to $5 \mu \mathrm{m}$ diam. and dense but discrete, up to $1.5 \mathrm{~mm}$ long and $0 \cdot 15 \mathrm{~mm}$ wide, white to pale yellowish brown rhizines composed of strongly agglutinated, parallel hyphae, becoming darker towards the centre; rhizines unbranched to occasionally branched at the tip and covered with tomentum at least two thirds up to the tip. Upper cortex paraplectenchymatous, 25$35 \mu \mathrm{m}$ thick with 4-5 $\mu \mathrm{m}$ thick epicortex, formed of 3-5 cell layers; algal layer 15-25 $\mu \mathrm{m}$ thick; medulla 100-150 $\mu \mathrm{m}$ thick; lower cortex paraplectenchymatous, $10-15 \mu \mathrm{m}$ thick, formed of 2-3 cell layers.

Apothecia abundant, cup-shaped, up to $7 \mathrm{~mm}$ diam., with thick, strongly prominent, crisp, pale grey margins; lobules 15-30 per apothecium, very irregular and usually branched or incised, with irregular projections on the outside; disc concave, orangebrown. Excipulum composed of more or less parallel, partly branched hyphae with wide lumina resembling a paraplectenchyma, 30$70 \mu \mathrm{m}$ wide, hyaline; hypothecium formed of densely intricate hyphae partially resembling a paraplectenchyma, $20-30 \mu \mathrm{m}$ high, pale yellowish. Hymenium 120-130 $\mu \mathrm{m}$ high, clear, with yellow-orange, strongly conglutinated, 10-20 $\mu \mathrm{m}$ high epithecium; asci narrowly clavate, $100-120 \times 9-13 \mu \mathrm{m}$. Ascospores narrowly fusiform, $60-80 \times 4-5 \mu \mathrm{m}$, 7-septate, hyaline.

Pycnidia not observed.

Secondary chemistry. Chemosyndrome A1: cortex with pseudocyphellarin A, K+ yellow; medulla with gyrophoric acid (major) and Lobariella unidentified 1 (major), $\mathrm{K}-, \mathrm{C}+$ pink-red.

Ecology. Lobariella reticulata has been collected only in the páramo of Sumapáz near Bogotá, Colombia. Other than the collections cited below, it was further observed several times in the field in a small area and hence is probably rather abundant, considering the extension of this páramo region. It is easily mistaken for L. pallida and therefore its abundance and distributional range must be studied further by careful field observations.

Notes. This new species is most similar to Lobariella pallida, and the only visible differences are the more distinctly reticulate maculae and the very irregular, crisp apothecial margins; fortunately, apothecia appear to be almost always present in both species. Phylogenetically, the species is not closely related to L. pallida but is sister to the cyanobacterial L. sipmanii (Fig. 3). Apart from the different photobiont, these two species also differ morphologically in lobe configuration and 
the smooth apothecial margins in the latter. The only similarity is found in the distinctly reticulate maculae.

Additional specimens examined. Colombia: Cundinamarca: Parque Nacional Natural Sumapáz, 3500-3700 m, 2011, Lücking 34100, 34101, 34104 (F).

\section{Lobariella rugulosa B. Moncada \& Lücking sp. nov.}

\section{MycoBank No.: MB801895}

Differing from Lobariella angustata in the rugulose-ridged lobules.

Type: Costa Rica, Puntarenas, La Amistad Biosphere Reserve, Las Alturas Biological Station, 1530 m, May 2012, Lücking 34631 (INB-holotype; F-isotype).

(Fig. 12D)

Thallus growing on trunks of trees, up to $10 \mathrm{~cm}$ diam., very closely attached; photobiont green (Dictyochloropsis). Individual lobes up to $5 \mathrm{~cm}$ long, with polytomous, truncate apices and sinuose margins (Parmelia-like), 3-5 mm wide, irregularly branched, forming more or less rounded thallus rosettes. Upper surface bright green when hydrated, pale grey when dry and becoming pale yellowish brown in the herbarium, rugulose from the margin and soon becoming ridged; maculae absent; pseudocyphellae present from the lobe tips, developing on the ridges, moderately dense (about 3-8 per $\mathrm{mm}^{2}$ ), visible as elongate to linear pores, $0 \cdot 2-3.0 \mathrm{~mm}$ long and $0 \cdot 10_{-}$ $0.15 \mathrm{~mm}$ wide, eventually forming fine cracks. Isidia absent. Lower surface creamcoloured to pale yellowish brown, with a short, dense, cream-coloured to pale brown tomentum formed of up to $30 \mu \mathrm{m}$ long hyphae composed of globose cells up to $5 \mu \mathrm{m}$ diam. and discrete, up to $1.5 \mathrm{~mm}$ long and $0.1 \mathrm{~mm}$ wide, cream-coloured to pale brown rhizines composed of strongly agglutinated, parallel hyphae; rhizines unbranched to sparsely branched at the tip and covered with tomentum towards the thallus centre. Upper cortex paraplectenchymatous, 20-30 $\mu \mathrm{m}$ thick with 3-5 $\mu \mathrm{m}$ thick epicortex, formed of 3-5 cell layers; algal layer 15-25 $\mu \mathrm{m}$ thick; medulla 80-130 $\mu \mathrm{m}$ thick; lower cortex paraplectenchymatous, $7-15 \mu \mathrm{m}$ thick, formed of 2(-3) cell layers.
Apothecia abundant, cup-shaped, up to $3 \mathrm{~mm}$ diam., with thick, strongly prominent, lobulate, grey to cream-coloured margins; lobules 7-15 per apothecium, more or less regular with rounded or rarely bifurcate tips; disc concave, orange-brown. Excipulum composed of more or less parallel, partly branched hyphae with wide lumina resembling a paraplectenchyma, 30-50 $\mu \mathrm{m}$ wide, hyaline; hypothecium formed of densely intricate hyphae partially resembling a paraplectenchyma, 15-30 $\mu \mathrm{m}$ high, pale yellowish. Hymenium 100-120 $\mu \mathrm{m}$ high, clear, with yellow-orange, strongly conglutinated, 10$20 \mu \mathrm{m}$ high epithecium; asci narrowly clavate, 90-110 $\times 10-14 \mu \mathrm{m}$. Ascospores narrowly fusiform, $60-80 \times 4-5 \mu \mathrm{m}, 7$-septate, hyaline.

Pycnidia not observed.

Secondary chemistry. Chemosyndrome B: cortex with undetectable traces of pseudocyphellarin A, K+ yellow; medulla with Lobariella unidentified 3 (major), 4-O-methylgyrophoric acid (major), gyrophoric acid (trace), and Lobariella unidentified 2 (minor), $\mathrm{K}+$ emerald green to sordid yellow, $\mathrm{C}-$.

Ecology. This species is known only from southern Costa Rican lower montane rainforest where it grows abundantly on tree trunks in semi-exposed situations. It is one of the most common large foliose lichens in the area.

Notes. This new species belongs in the group of taxa with Lobariella crenulata-like morphology but chemosyndrome B medullary chemistry. Among these, it is readily characterized by the very narrow, closely adnate thallus lobes with rugose-ridged surface, by which it is distinguished from L. angustata. Another difference appears to be the vividly green colour of fresh specimens, whereas L. angustata is grey-green in the field. Thus far, L. rugulosa has been found only in a narrow range in Costa Rican lower montane rainforest.

Additional specimens examined. Costa Rica: Puntarenas: La Amistad Biosphere Reserve, Las Alturas Biological Station, 1530 m, 2012, Moncada 5728, 5755 (F, UDBC); La Amistad Biosphere Reserve, Altamira Station, 1450 m, 2002, Lücking 152391 (F, INB); La Amistad Biosphere Reserve, Altamira Station, Casa Coca trail, 1600-1800 m, 2002, Lücking 15250c (F, INB); 
Las Tablas Protection Zone, Los Portones, 1400 m, 2002, Lücking 15143c (INB).

\section{Lobariella sipmanii B. Moncada, Betancourt \& Lücking}

in Lumbsch et al., Phytotaxa 18: 82 (2011); type: Colombia, Lücking et al. s. n. (UDBC-holotype; F-isotype).

(Fig. 12E)

Notes. For a detailed description of this species, see Lumbsch et al. (2011). Lobariella sipmanii is unique in its combination of cyanobacterial photobiont and abundant apothecia, whereas isidia or soralia are lacking. In addition, it is the only species in the genus in which the apothecial margin is more or less entire, and the only species with a conspicuous network of reticulate maculae. Phylogenetically, it is sister to L. reticulata (Fig. 3) which, apart from its green photobiont, differs in having lobulate apothecial margins. Otherwise, the reticulate maculae and chemistry are shared between the two species, although the maculae are less contrasting with the thallus surface in L. reticulata.

Lobariella sipmanii is a characteristic páramo lichen, being locally abundant especially in the páramo of Sumapáz, but not as frequent as L. pallida. Like the latter, it mostly grows on twigs and branches of shrubs and treelets, in semi-exposed to exposed microsites.

Specimens examined. Colombia: Cauca: Parque Nacional Natural Puracé, 3200-3500 m, 2011, Diaz E Soto L11 (F, UDBC). Cundinamarca: Parque Nacional Natural Chingaza, 3100-3600 m, 2011, Moncada 4651 (UDBC); Parque Nacional Natural Sumapáz, 35003700 m, 2010, Moncada 4077, 4084, 4087, 4098 (UDBC).

\section{Lobariella soredians B. Moncada, Betancourt-Macuase \& Lücking sp. nov.}

\section{MycoBank No.: MB801896}

Differing from Lobariella botryoides in the predominantly marginal, linear, finely granular soralia.

Type: Colombia, Cundinamarca, Parque Nacional Natural Sumapáz, 3500-3700 m, 13 April 2011, Moncada 4652 (UDBC-holotype; F-isotype).

(Fig. 12F)

Thallus growing on thin trunks, stems, and branches, up to $5 \mathrm{~cm}$ diam., more or less closely attached but with undulate to ascending lobes; photobiont blue-green (Nostoc). Individual lobes up to $2 \mathrm{~cm}$ long, rounded with entire to shallowly incised margins, $5-8 \mathrm{~mm}$ wide, sparsely branched, forming more or less circular thallus rosettes. Upper surface bluish grey when hydrated, pale grey when dry and becoming pale yellowish grey in the herbarium, uneven but not ridged or scrobiculate; maculae indistict, white, forming a reticulate network at the very lobe tips; pseudocyphellae developing from marginal maculae, at first remaining indistinct but eventually forming a network of thin cracks $0 \cdot 05-0 \cdot 10$ $\mathrm{mm}$ wide. Soralia abundant, predominantly produced at the lobe margins but sometimes also along cracks in the surface, linear; soredia finely granular, granules blue-green to grey-brown. Lower surface cream-coloured to pale yellowish brown, with a very short, dense, pale yellowish brown tomentum formed of up to $25 \mu \mathrm{m}$ long hyphae composed of globose cells up to $5 \mu \mathrm{m}$ diam., and discrete, up to $0.5 \mathrm{~mm}$ long and $0.1 \mathrm{~mm}$ wide, pale yellowish brown rhizines composed of strongly agglutinated, parallel hyphae; rhizines unbranched to irregularly branched at the tip and covered with tomentum. Upper cortex paraplectenchymatous, $20-30 \mu \mathrm{m}$ thick with 3-5 $\mu \mathrm{m}$ thick epicortex, formed of 3-5 cell layers; algal layer $25-50 \mu \mathrm{m}$ thick; medulla 80-120 $\mu \mathrm{m}$ thick; lower cortex paraplectenchymatous, $10-15 \mu \mathrm{m}$ thick, formed of $2-3$ cell layers.

\section{Apothecia and pycnidia not observed.}

Secondary chemistry. Chemosyndrome A1: cortex with pseudocyphellarin A, K+ yellow; medulla with gyrophoric acid (major) and methyl-gyrophorate (major), $\mathrm{K}-, \mathrm{C}+$ pinkred.

Ecology. This species appears to be a characteristic páramo lichen, but is apparently rare. In contrast to Lobariella pallida, it grows more in semi-shaded microsites, often hidden between other lichens.

Notes. This new species would key out to Lobariella botryoides using the key of Yoshimura \& Arvidsson (1994), but it differs from the latter in several important aspects: the 
soralia are more finely granular and predominantly formed at the margin and not from polyisidiangia, the pseudocyphellae develop from a network of marginal, reticulate maculae, and the lobes are more regularly rounded and have an even to uneven but not scrobiculate or ridged surface. Lobariella soredians superficially resembles a species of Parmotrema when dry, both in lobe configuration, colour, and marginal soralia. However, a closer look immediately reveals the many morphological differences.

Specimens examined. Colombia: Boyacá: Municipio El Cocuy, Parque Nacional Natural El Cocuy, Alto de la Cueva, 3800 m, 2011, Fonseca \& Martinez 65, 152 (F, UDBC). Cundinamarca: Parque Nacional Natural Sumapáz, 3500-3700 m, 2008, Ardila 215 (UDBC); ibid., 2010, Moncada 4071 (UDBC).

\section{Lobariella spathulifera B. Moncada \& Lücking sp. nov.}

\section{MycoBank No.: MB801897}

Differing from Lobariella auriculata in the apically broadened, spatulate isidia and the $\mathrm{C}+$ orange medullary reaction along the pseudocyphellae.

Type: Costa Rica, San José, Los Santos Forest Reserve, Cerro de la Muerte Biological Station, $83^{\circ} 45^{\prime} \mathrm{W}$, $9^{\circ} 34^{\prime} \mathrm{N}, 3100-3400 \mathrm{~m}$, upper montane cloud forest, 3 July 2002, Lücking 15355 (F-holotype).

(Fig. 13A)

Thallus growing on trunks and stems, up to $10 \mathrm{~cm}$ diam., rather loosely attached; photobiont green (Dictyochloropsis). Individual lobes up to $5 \mathrm{~cm}$ long, irregular with rounded apices and more or less entire margins, 7-15 mm wide, irregularly branched, forming more or less irregular thallus rosettes. Upper surface bright green when hydrated, pale grey when dry and becoming pale yellowish brown in the herbarium, shallowly to distinctly ridged especially towards the centre; maculae absent; pseudocyphellae present from the lobe tips, starting out as irregular, white lines $0.10 \times 0.05 \mathrm{~mm}$ diam. but soon becoming elongate, up to $2 \mathrm{~mm}$ long and $0.2 \mathrm{~mm}$ wide and developing cracks towards the centre. Isidia abundant, developing in groups on the pseudocyphellae or ridges, at first dark brown to brown-black and globose but soon becoming flattened with darkened and broadened tip, resem- bling the apothecial appendages of the crustose lichen Auriculora Kalb, then up to 0.07 $\mathrm{mm}$ thick and $0.2-0.3 \mathrm{~mm}$ wide and high, eventually in older thallus parts up to $2 \mathrm{~mm}$ long and much branched, always remaining completely flattened and retaining dark tips, broadened towards the tips and appearing spatulate. Lower surface pale yellowish brown, with a short, dense, pale brown tomentum formed of up to $30 \mu \mathrm{m}$ long hyphae composed of globose cells up to $5 \mu \mathrm{m}$ diam. and discrete, up to $1 \mathrm{~mm}$ long and $0.15 \mathrm{~mm}$ wide, pale rhizines composed of strongly agglutinated, parallel hyphae; rhizines unbranched to sparsely branched at the tip and covered with tomentum towards the thallus centre. Upper cortex paraplectenchymatous, 20-30 $\mu \mathrm{m}$ thick with 3-5 $\mu \mathrm{m}$ thick epicortex, formed of 3-5 cell layers; algal layer 15-25 $\mu \mathrm{m}$ thick; medulla 80-130 $\mu \mathrm{m}$ thick; lower cortex paraplectenchymatous, $7-15 \mu \mathrm{m}$ thick, formed of 2(-3) cell layers.

Apothecia and pycnidia not observed.

Secondary chemistry. Chemosyndrome B: cortex with pseudocyphellarin A, K+ yellow; medulla with Lobariella unidentified 3 (major), 4-O-methyl-gyrophoric acid (major), gyrophoric acid (minor), and Lobariella unidentified 2 (minor), $\mathrm{K}+$ emerald green to sordid yellow, C+ weakly salmon-rose or patchily bright orange along pseudocyphellae.

Ecology. Known only from the type locality in the transitional zone between subandine cloud forest and páramo.

Notes. This new species is known only from one collection and is very close to $\mathrm{Lo}$ bariella auriculata. The development of the isidia is slightly different, with mature isidia becoming broadened towards the apex, resembling a spatula; also, the lower tomentum is pale, while it is dark in L. auriculata. The other significant difference, and a character not known from any other species in the genus, is the patchily $\mathrm{C}+$ bright orange reaction of the upper medulla bordering the pseudocyphellae. It is not known which substance causes this reaction, since the TLC profile was found to be identical to that of $L$. auriculata, which lacks such a reaction. 

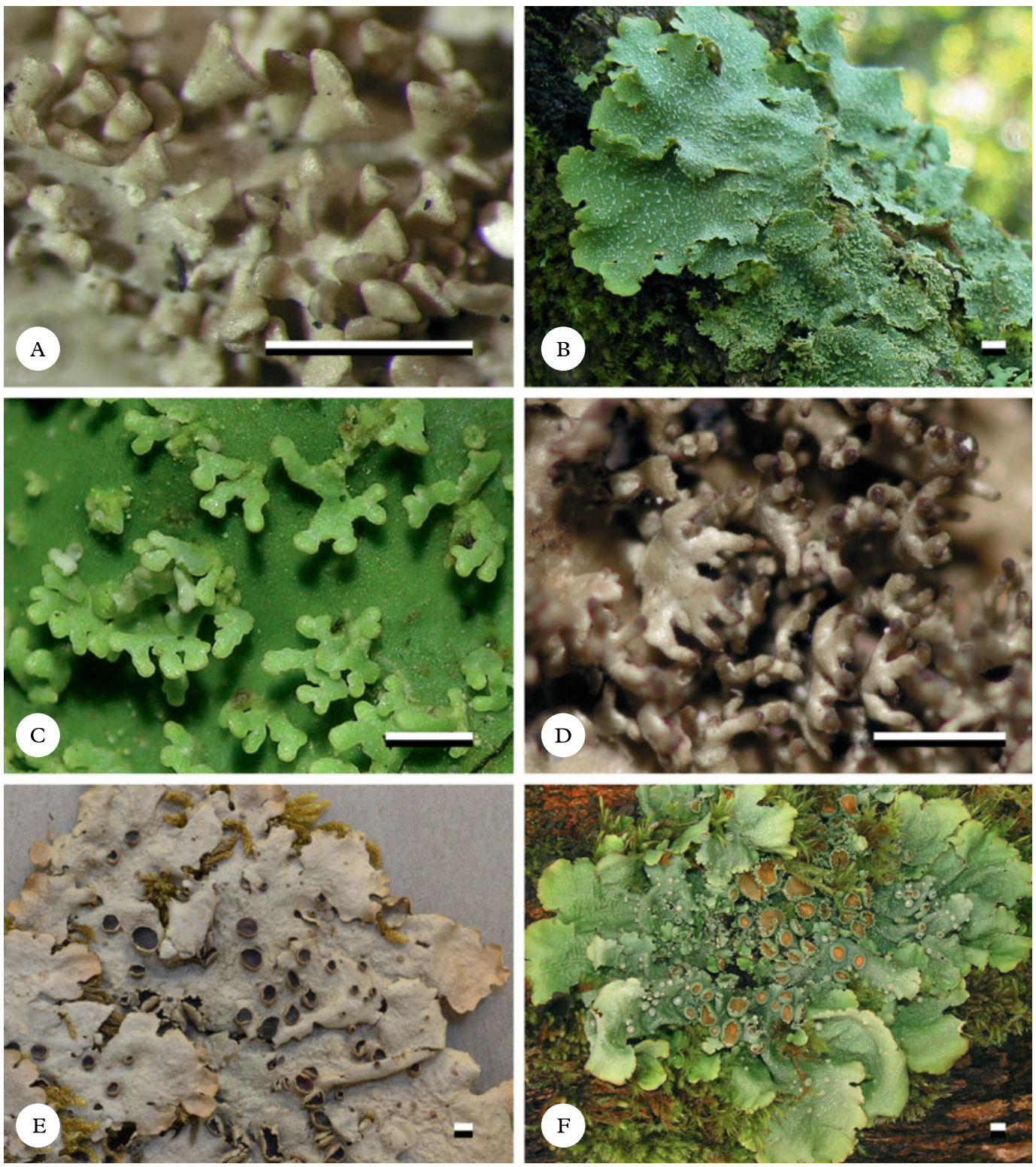

FIG. 13. Habit of Lobariella species. A, L. spathulifera (holotype), showing enlarged isidia; B \& C, L. stenroosiae (Lücking 30121), showing upper side with pseudocyphellae and isidia (B) and isidia enlarged (C); D, L. subcorallophora (holotype), showing enlarged isidia; E \& F, L. subcrenulata (E, holotype; F, Lücking 15515b), showing upper side with apothecia. Scale $=1 \mathrm{~mm}$. In colour online.

\section{Lobariella stenroosiae B. Moncada \& Lücking sp. nov.}

\section{MycoBank No.: MB801898}

Differing from Lobariella nashii in the sparsely branched, more irregular phyllidia.
Type: Brazil, Minas Gerais, Parque Nacional de Itatiaia, 2000 m, 1997, Stenroos 5088b (H-holotype).

(Fig. 13B \& C)

Thallus growing on trunks and stems, up to $15 \mathrm{~cm}$ diam., rather closely attached; pho- 
tobiont green (Dictyochloropsis). Individual lobes up to $7 \mathrm{~cm}$ long, with rounded to irregular apices and irregularly incised margins, 7-15 mm wide, irregularly branched, forming more or less irregular thallus rosettes. Upper surface bright green when hydrated, pale grey when dry and becoming pale yellowish brown in the herbarium, uneven to shallowly ridged towards the centre; maculae absent; pseudocyphellae present from the lobe tips, usually on the ridges, moderately dense (3-7 per $\mathrm{mm}^{2}$ ) starting out as irregular, white spots but soon becoming elongate-linear, up to $2 \mathrm{~mm}$ long and $0.2 \mathrm{~mm}$ wide and developing distinct linear cracks towards the centre. Phyllidia abundant, usually developing from pseudocyphellae or ridges, concolorous with the thallus, flattened and phyllidiate from the beginning, rarely becoming peltate, irregularly branched, up to $2 \mathrm{~mm}$ long and individual branches $0 \cdot 2-0 \cdot 3 \mathrm{~mm}$ wide. Lower surface cream-coloured to pale yellowish brown, with a short, dense, cream-coloured to pale brown tomentum formed of up to $30 \mu \mathrm{m}$ long hyphae composed of globose cells up to $5 \mu \mathrm{m}$ diam. and discrete, up to $1 \mathrm{~mm}$ long and $0.15 \mathrm{~mm}$ wide, creamcoloured to pale brown rhizines composed of strongly agglutinated, parallel hyphae; rhizines unbranched to sparsely branched at the tip and covered with tomentum towards the thallus centre. Upper cortex paraplectenchymatous, $20-30 \mu \mathrm{m}$ thick with $3-5 \mu \mathrm{m}$ thick epicortex, formed of 3-5 cell layers; algal layer $15-25 \mu \mathrm{m}$ thick; medulla $80-130$ $\mu \mathrm{m}$ thick; lower cortex paraplectenchymatous, $7-15 \mu \mathrm{m}$ thick, formed of 2(-3) cell layers.

Apothecia and pycnidia not observed.

Secondary chemistry. Chemosyndrome B: cortex with traces of pseudocyphellarin A, $\mathrm{K}+$ yellow; medulla with Lobariella unidentified 3 (major), 4-O-methyl-gyrophoric acid (major), gyrophoric acid (minor), and Lobariella unidentified 2 (minor), $\mathrm{K}+$ emerald green to sordid yellow, C+ weakly salmonrose.

Ecology. This appears to be a relatively widespread species in montane rainforests in South America, found on tree trunks in semi-shaded situations.
Notes. This species agrees in most features with Lobariella subexornata (Yoshimura 1984, 1998; Yoshimura \& Arvidsson 1994), but the medullary chemistry is different (chemosyndrome B vs A1). Lobariella stenroosiae was originally identified as $L$. crenulata, with an ITS sequence available in GenBank (AF524922). The material actually contains two different species with different morphology and chemistry, the other being $L$. exornata (see above), and the two are here separated as Stenroos 5088a and 5088b; the latter, representing the type of L. stenroosiae, is the one that was sequenced (S. Stenroos, pers. comm. 2012). Lobariella nashii is similar in most features but has more regularly and abundantly branched phyllidia with narrower branches $(0.2$ vs $0.3 \mathrm{~mm})$; both species are phylogenetically distinct (Fig. 3).

Additional specimens examined. Colombia: Boyacá: Villa de Leyva, Santuario de Fauna y Flora Iguaque, trail from administrative building to Villa de Leyva, 2800 2850 m, 2002, Moncada \& Dávila 1699, 1780 (UDBC).-Brazil: Minas Gerais: Parque Nacional de Itatiaia, 2000 m, 2009, Lücking 30121 (F, SP).

\section{Lobariella subcorallophora B. Moncada \& Lücking sp. nov.}

\section{MycoBank No.: MB801899}

Differing from Lobariella corallophora in the medullary chemistry, with Lobariella unidentified 3 as the main substance $(\mathrm{K}+$ emerald green) and lacking gyrophoric acid.

Type: Colombia, Norte de Santander, Parque Nacional Natural Tamá, Sector Orocué, 2800 m, 2000, Moncada E Dávila 1032 (UDBC-holotype).

\section{(Fig. 13D)}

Thallus growing on trunks and stems, up to $10 \mathrm{~cm}$ diam., rather loosely attached; photobiont green (Dictyochloropsis). Individual lobes up to $5 \mathrm{~cm}$ long, irregular with rounded to more or less truncate apices and irregularly incised margins, 7-15 mm wide, irregularly branched, forming more or less irregular thallus rosettes. Upper surface bright green when hydrated, pale grey when dry and becoming pale yellowish brown in the herbarium, shallowly to distinctly ridged especially towards the centre; maculae absent; pseudocyphellae present from the lobe tips, starting out as irregular, white lines $0.10 \times 0.05 \mathrm{~mm}$ 
diam. but soon becoming elongate-linear up to $3 \mathrm{~mm}$ long and $0.3 \mathrm{~mm}$ wide and developing distinct linear cracks towards the centre. Isidia abundant, developing in groups on the pseudocyphellae or ridges, at first dark brown to brown-black and globose, remaining mostly cylindrical but soon branched and becoming coralloid, then with the base distinctly flattened, then up to $0.1 \mathrm{~mm}$ thick and the base $0 \cdot 2-0.3 \mathrm{~mm}$ wide, when mature up to $2 \mathrm{~mm}$ long, retaining dark tips. Lower surface pale yellowish brown to brown, with a short, dense, pale to dark brown tomentum formed of up to $30 \mu \mathrm{m}$ long hyphae composed of globose cells up to $5 \mu \mathrm{m}$ diam. and discrete, up to $1 \mathrm{~mm}$ long and $0.15 \mathrm{~mm}$ wide, pale to dark brown rhizines composed of strongly agglutinated, parallel hyphae; rhizines unbranched to sparsely branched at the tip and covered with tomentum towards the thallus centre. Upper cortex paraplectenchymatous, $20-30 \mu \mathrm{m}$ thick with $3-5 \mu \mathrm{m}$ thick epicortex, formed of 3-5 cell layers; algal layer 15-25 $\mu \mathrm{m}$ thick; medulla 80-130 $\mu \mathrm{m}$ thick; lower cortex paraplectenchymatous, 7-15 $\mu \mathrm{m}$ thick, formed of 2(-3) cell layers.

Apothecia and pycnidia not observed.

Secondary chemistry. Chemosyndrome B: cortex with pseudocyphellarin A, K+ yellow; medulla with Lobariella unidentified 3 (major), 4-O-methyl-gyrophoric acid (major), gyrophoric acid (minor), and Lobariella unidentified 2 (minor), $\mathrm{K}+$ emerald green to sordid yellow, C+ weakly salmon-rose.

Ecology. Known only from two collections in the transitional zone between subandine cloud forest and páramo.

Notes. This new species was at first identified as Lobaria corallophora, but the medullary chemistry is distinct, since the latter has gyrophoric acid as the main medullary substance (C+ pink-red) and lacks Lobariella unidentified 3. The species is otherwise most similar to L. auriculata both in morphology and chemistry, but the isidia in the latter are flattened from the beginning and retain flattened instead of cylindrical terminal branches.

Specimens examined. Colombia: Cundinamarca: Parque Nacional Natural Chingaza, 3100-3600 m, 2003, Moncada \& Dávila 1484 (UDBC).

\section{Lobariella subcrenulata B. Moncada \& Lücking sp. nov.}

MycoBank No.: MB801900

Differing from Lobariella crenulata in the broader (7-15 vs $5-10 \mathrm{~mm}$ ), rounded lobes and the medullary chemistry, containing Lobariella unidentified 3 ( $\mathrm{K}+$ emerald green) instead of gyrophoric acid (C+ pink-red) as the major substance.

Type: Costa Rica, Cartago, Irazú National Park, 3300 m, 22 March 2003, Lutzoni et al. 03.22.03-11\#2 (DUKE-holotype).

(Fig. 13E \& F)

Thallus growing on trunks and stems, up to $12 \mathrm{~cm}$ diam., more or less closely attached; photobiont green (Dictyochloropsis). Individual lobes up to $6 \mathrm{~cm}$ long, with rounded apices and entire margins, $7-15 \mathrm{~mm}$ wide, regularly branched, forming more or less rounded thallus rosettes. Upper surface bright green when hydrated, pale grey when dry and becoming pale yellowish brown in the herbarium, smooth to slightly uneven towards the centre; maculae absent; pseudocyphellae present from the lobe tips, visible as irregular, white lines $0.10 \times 0.05 \mathrm{~mm}$ diam., becoming elongate-linear up to $2 \mathrm{~mm}$ long and $0.2 \mathrm{~mm}$ wide towards the centre. Isidia absent. Lower surface cream-coloured to pale yellowish brown, with a short, dense, creamcoloured to pale brown tomentum formed of up to $30 \mu \mathrm{m}$ long hyphae composed of globose cells up to $5 \mu \mathrm{m}$ diam. and discrete, up to $1 \mathrm{~mm}$ long and $0.1 \mathrm{~mm}$ wide, creamcoloured to pale brown rhizines composed of strongly agglutinated, parallel hyphae; rhizines unbranched to sparsely branched at the tip and covered with tomentum towards the thallus centre. Upper cortex paraplectenchymatous, $20-30 \mu \mathrm{m}$ thick with 3-5 $\mu \mathrm{m}$ thick epicortex, formed of 3-5 cell layers; algal layer 15-25 $\mu \mathrm{m}$ thick; medulla 80-140 $\mu \mathrm{m}$ thick; lower cortex paraplectenchymatous, 7-15 $\mu \mathrm{m}$ thick, formed of 2(-3) cell layers.

Apothecia abundant, cup-shaped, up to $5 \mathrm{~mm}$ diam., with thick, strongly prominent, lobulate, grey to cream-coloured margins; lobules 7-15 per apothecium, more or less regular with rounded or rarely bifurcate tips; disc concave, orange-brown. Excipulum composed of more or less parallel, partly branched hyphae with wide lumina resembling a para- 
plectenchyma, 40-60 $\mu \mathrm{m}$ wide, hyaline; $h y$ pothecium formed of densely intricate hyphae partially resembling a paraplectenchyma, 20$30 \mu \mathrm{m}$ high, pale yellowish. Hymenium 120$140 \mu \mathrm{m}$ high, clear, with yellow-orange, strongly conglutinated, $10-20 \mu \mathrm{m}$ high epithecium; asci narrowly clavate, 110-130 × 10$13 \mu \mathrm{m}$. Ascospores narrowly fusiform, 65$80 \times 3.5-4.5 \mu \mathrm{m}, 7$-septate, hyaline.

Pycnidia not observed.

Secondary chemistry. Chemosyndrome B: cortex with undetectable traces of pseudocyphellarin A, K+ yellow; medulla with Lobariella unidentified 3 (major), 4-O-methylgyrophoric acid (major), gyrophoric acid (trace), and Lobariella unidentified 2 (minor), $\mathrm{K}+$ emerald green to sordid yellow, $\mathrm{C}-$.

Ecology. This appears to be a subandine cloud forest species, thus far known only from the type locality, growing in semiexposed situations on the trunks of trees.

Notes. This is another species that shares its gross morphology with Lobariella crenulata but belongs in the group having chemosyndrome B with regard to medullary chemistry. Among the four species in this group with apothecia, including $L$. angustata, L. olivascens, and L. pseudocrenulata, it is distinguished by the combination of rather broad, rounded lobes and the lack of marginal maculae. This species was identified as L. pallida in GenBank (AFTOL ID 314: DQ883740, DQ883753, DQ883772, DQ883788, DQ883797, DQ912297, HQ650696), but differs from the latter in morphology (pseudocyphellate instead of hypermaculate) and medullary chemistry (chemosyndrome B instead of A1a).

Additional specimens examined. Costa Rica: Cartago: Irazú National Park, 3400 m, 2002, Lücking 15480, 15515b (F).

\section{Lobariella subexornata (Yoshim.) Yoshim.}

in Nash et al., Lichen Flora of the Greater Sonoran Desert Region 1: 272 (2002).-Lobaria subexornata Yoshim. in Yoshimura \& Arvidsson, Acta Bot. Fenn. 150: 233 (1994); type: Costa Rica, Yoshimura 79930a (NICHholotype, not seen).
Notes. For a detailed description of this species, see Yoshimura (1984) and Yoshimura \& Arvidsson (1994). Lobariella subexornata is similar to L. crenulata and L. exornata in thallus morphology (including the lack of corticate maculae) and medullary chemistry. It is distinguished by the flattened isidia that are unbranched or often sparsely dichotomously branched. Also, in contrast to $L$. exornata, the apothecial margin is usually densely isidiate and appearing as if formed of numerous, delicate lobules. Most similar is L. stenroosiae, which differs in the medullary chemistry (chemosyndrome B vs A1). Lobariella corallophora and L. ecorticata both have branched isidia with flattened base; however, in L. subexornata, the terminal branches are also distinctly flattened whereas in the other two species they are more or less cylindrical. In addition, L. corallophora differs in having isidia with dark tips, and the pseudocyphellae develop from marginal maculae, whereas L. ecorticata has isidia with ecorticate undersides. The latter species also has a slightly different medullary chemistry, with lecanoric instead of gyrophoric acid as the main compound.

This study was supported by two grants from the National Science Foundation: TICOLICHEN (DEB 0206125 to The Field Museum; PI Robert Lücking), and Neotropical Epiphytic Microlichens - An Innovative Inventory of a Highly Diverse yet Little Known Group of Symbiotic Organisms (DEB 715660 to The Field Museum; PI R. Lücking). The Caterpillar ${ }^{\circledR}$ Company and Field Museum donor and board member Robert $\mathrm{H}$. Gordon provided additional funds for the molecular studies. All molecular work was carried out by the first author in the Pritzker Laboratory of Molecular Systematics and Evolution at the Field Museum, and Thorsten Lumbsch and Sittiporn Parnmen are thanked for assistance. The Universidad Distrital Francisco José de Caldas is thanked for the support to the lichen herbarium and the curatorial work of the UDBC collections, and we especially acknowledge the invaluable help of laboratory assistant Alejandra Suárez. We greatly appreciate the support of the Sistema Nacional de Áreas de Conservación (SINAC) and the Ministerio de Ambiente y Energía (MINAE) in receiving collection and work permits for Costa Rica, and the assistance of Álvaro Herrera and Milagros Mata from INBio in obtaining these permits. The curators of the herbaria cited in this monograph, in particular Carlos Parra (COL), Michaela Schmull $(\mathrm{FH})$, Soili Stenroos $(\mathrm{H})$, Bruno Dennetière (PC), and Holger Thüs (BM), were extremely helpful in providing access to type material and other relevant 
collections and data. Adriano Spielmann and Luciana Cañez are thanked for providing additional collections and field images from Brazil, and Leidy Vargas, Leidy Herrera, Luis Fernando Coca, David Díaz Escandón, and Edier Soto for providing additional collections from Colombia. David J. Galloway and an anonymous reviewer helped to improve this manuscript considerably.

\section{REFERENCES}

Acharius, E. (1803) Methodus qua omnes detectos lichenes secundum organa carpomorpha ad genera, species et varietates redigere atque observationibus illustrare tentavit Erik Acharius (Methodus Lichenum). Cum tab. aen. Stockholm: Ulrich.

Acharius, E. (1810) Lichenographia Universalis. Cum tab. aen. color. Göttingen: Danckwerts.

Argüello, A., Del Prado, R., Cubas, P. \& Crespo, A. (2007) Parmelia quercina (Parmeliaceae, Lecanorales) includes four phylogenetically supported morphospecies. Biological fournal of the Linnean Society 91: 455-467.

Awasthi, D. D. (2007) A Compendium of the Macrolichens from India, Nepal and Sri Lanka. Dehra-Dun, India: Bishen Singh Mahendra Pal Singh.

Cannon, P. F. \& Kirk, P. M. (2007) Fungal Families of the World. Wallingford: CAB International.

Chen, J.-B. (1993) Chemical notes on three species of Sticta from China. Lichenologist 25: 455-458.

Chen, J., Wang, Z. \& Wang, L. (1994) The lichen genus Sticta from Yunnan of China. Acta Mycologica Sinica 13: 29-33.

Clements, F. E. (1909) The Genera of Fungi. Minneapolis: H. W. Wilson.

Cornejo, C. \& Scheidegger, C. (2010) Lobaria macaronesica sp. nov., and the phylogeny of Lobaria sect. Lobaria (Lobariaceae) in Macaronesia. Bryologist 113: 590-604.

Crespo, A. \& Lumbsch, H. T. (2010) Cryptic species in lichen-forming fungi. IMA Fungus 1: 167-170.

Crespo, A. \& Pérez-Ortega, S. (2009) Cryptic species and species pairs in lichens: a discussion on the relationship between molecular phylogenetics and morphological characters. Anales del fardín Botánico de Madrid 66S1: 71-81.

Crespo, A., Molina, M. C., Blanco, O., Schroeter, B., Sancho, L. G. \& Hawksworth, D. L. (2002) rDNA ITS and -tubulin gene sequence analyses reveal two monophyletic groups within the cosmopolitan lichen Parmelia saxatilis. Mycological Research 106: 788-795.

Culberson, C. F., Culberson, W. L. \& Johnson, A. (1977) Second Supplement to 'Chemical and Botanical Guide to Lichen Products'. Missouri Botanical Garden, St. Louis: American Bryological and Lichenological Society.

Delise, D. (1822) Histoire de Lichens. Genre Sticta. Caen: Chalopin.

Divakar, P. K., Blanco, O., Hawksworth, D. L. \& Crespo, A. (2005) Molecular phylogenetic studies on the Parmotrema reticulatum (syn. Rimelia reticulata) complex, including the confirmation of $P$. pseudoreticulatum. Lichenologist 37: 55-65.
Drummond, A. J. \& Rambaut, A. (2007) BEAST: Bayesian evolutionary analysis by sampling trees. $B M C$ Evolutionary Biology 7: 214.

Elix, J. A. \& Tønsberg, T. (2006) Notes on the chemistry of Scandinavian Lobaria species. Graphis Scripta 18: $27-28$.

Galloway, D. J. (1988) Studies in Pseudocyphellaria (lichens) I. The New Zealand species. Bulletin of the British Museum (Natural History), Botany Series 17: 1-267.

Galloway, D. J. (1992) Studies in Pseudocyphellaria (lichens) III. The South American species. Bibliotheca Lichenologica 46: 1-275.

Galloway, D. J. (1994) Studies in Pseudocyphellaria (lichens) IV. Palaeotropical species (excluding Australia). Bulletin of the Natural History Museum, London 24: 115-159.

Galloway, D. J. (1995) The extra-European lichen collections of Archibald Menzies MD, FLS (17541842). Edinburgh fournal of Botany 52: 95-139.

Galloway, D. J. (1997) Studies on the lichen genus Sticta (Schreber) Ach. IV. New Zealand species. Lichenologist 29: 105-168.

Galloway, D. J. (2007) Flora of New Zealand Lichens. Revised Second Edition Including Lichen-Forming and Lichenicolous Fungi. Volumes 1 and 2. Lincoln, New Zealand: Manaaki Whenua Press.

Galloway, D. J. \& Arvidsson, L. (1990) Studies in Pseudocyphellaria (lichens) II. Ecuadorean species. Lichenologist 22: 103-135.

Galloway, D. J. \& Laundon, J. R. (1988) Proposal to conserve Pseudocyphellaria against several names (Ascomycotina, Lobariaceae). Taxon 37: 480-482.

Galloway, D. J., James, P. W. \& Wilkins, A. L. (1983) Further nomenclatural and chemical notes on Pseudocyphellaria in New Zealand. Lichenologist 15: 135145.

Gardes, M. \& Bruns, T. D. (1993) ITS primers with enhanced specificity for basidiomycetes - application to the identification of mycorrhizae and rust. Molecular Ecology 2: 113-118.

Goffinet, B. \& Goward, T. (1998) Is Nephroma silvaeveteris the cyanomorph of Lobaria oregana? Insights from molecular, chemical and morphological characters. In Lichenographia Thomsoniana: North American Lichenology in Honor of fohn W. Thomson (M. G. Glenn, R. C. Harris, R. Dirig \& M. S. Cole, eds): 41-52. Ithaca, New York: Mycotaxon Ltd.

Goward, T., McCune, B. \& Meidinger, D. (1994) The Lichens of British Columbia. Illustrated Keys. Part 1 Foliose and Squamulose Species. Special Report Series, 8, Research Program, B.C. Ministry of Forests. Victoria, Canada: Crown Publications.

Gyelnik, V. (1935) De familia Heppiacearum, II. Feddes Repertorium Specierum Novarum Regni Vegetabilis 38: 307-313.

Hall, T. A. (1999) BioEdit: a user-friendly biological sequence alignment editor and analysis program for Windows 95/98/NT. Nucleic Acids Symposium Series 41: 95-98.

Harris, R. A. (1979) A glossary of surface sculpturing. California Department of Food and Agriculture, Bureau of Entomology 28: 1-31. 
Högnabba, F., Stenroos, S. \& Thell, A. (2009) Phylogenetic relationship and evolution of photobiont associations in the Lobariaceae (Peltigerales, Lecanoromycetes, Ascomycota). Bibliotheca Lichenologica 100: 157-187.

Jørgensen, P. M. \& Galloway, D. J. (2011) Proposal to conserve Pseudocyphellaria, nom. cons (Lobariaceae: Ascomycota) with a conserved type. Taxon 60: 1770-1771.

Katoh, K., Misawa, K., Kuma, K. \& Miyata, T. (2002) MAFFT: a novel method for rapid multiple sequence alignment based on fast Fourier transform. Nucleic Acids Research 30: 3059-3066.

Katoh, K., Asimenos, G. \& Toh, H. (2009) Multiple alignment of DNA sequences with MAFFT. Methods in Molecular Biology 537: 39-64.

Kauff, F. \& Lutzoni, F. (2002) Phylogeny of Gyalectales and Ostropales (Ascomycota, Fungi): among and within order relationships based on nuclear ribosomal RNA small and large subunits. Molecular Phylogeny and Evolution 25: 138-156.

Kirk, P. M., Cannon, P. F., Minter, D. W. \& Stalpers, J. A. (2008) Dictionary of the Fungi. 10th edn. Wallingford: CAB International.

Kondratyuk, S. Y. \& Galloway, D. J. (1995) Lichenicolous fungi and chemical patterns in Pseudocyphellaria. Bibliotheca Lichenologica 57: 327-345.

Link, H. F. (1833) Handbuch zur Erkennung der Nutzbarsten und am Häufigsten Vorkommenden Gewächse. Berlin: Haude und Spener.

Lücking, R., Rivas Plata, E., Chaves, J. L., Umaña, L. \& Sipman, H. J. M. (2009). How many tropical lichens are there... really? Bibliotheca Lichenologica 100: $399-418$.

Lücking, R., Hodkinson, B. P., Stamatakis, A. \& Cartwright, R. A. (2011) PICS-Ord: unlimited coding of ambiguous regions by Pairwise Identity and Cost Scores Ordination. BMC Bioinformatics 12: 10.

Lumbsch, H. T. (2002). Analysis of phenolic products in lichens for identification and taxonomy. In Protocols in Lichenology. Culturing, Biochemistry, Ecophysiology and Use in Biomonitoring (I. Kranner, R. P. Beckett \& A. K. Varma, eds): 281-295. Berlin: Springer.

Lumbsch, H. T., Ahti, T., Altermann, S., Amo De Paz, G., Aptroot, A., Arup, U., Bárcenas Peña, A., Bawingan, P. A., Benatti, M. N., Betancourt, L. et al. (2011) One hundred new species of lichenized fungi: a signature of undiscovered global diversity. Phytotaxa 18: 1-127.

Magnusson, A. H. (1940) Studies in species of Pseudocyphellaria - the crocata group. Acta Horti Gothoburgensis 14: 1-36.

Mangold, A., Martín, M. A., Lücking, R. \& Lumbsch, H. T. (2008). Molecular phylogeny suggests synonymy of Thelotremataceae within Graphidaceae (Ascomycota: Ostropales). Taxon 57: 476-486.

Mason-Gamer, R. J. \& Kellogg, E. A. (1997) Testing for phylogenetic conflict among molecular data sets in the tribe Triticeae (Gramineae). Systematic Biology 45: 524-545.

Miądlikowska, J. \& Lutzoni, F. (2000) Phylogenetic revision of the genus Peltigera (lichen-forming Asco- mycota) based on morphological, chemical and large subunit nuclear ribosomal DNA data. International Fournal of Plant Science 161: 925-968.

Miądlikowska, J. \& Lutzoni, F. (2004) Phylogenetic classification of Peltigeralean fungi (Peltigerales, Ascomycota). American fournal of Botany 91: 449464.

Miądlikowska, J., McCune, B. \& Lutzoni, F. (2002) Pseudocyphellaria perpetua, a new lichen from western North America. Bryologist 105: 1-10.

Moncada, B. (2012) Diversity, ecogeography, and systematics of the lichen genus Sticta in Colombia. In Abstracts of the 7th IAL Symposium, 9-13 fanuary 2012, Bangkok, Thailand, p. 127.

Moncada, B. \& Lücking, R. (2012) Ten new species of Sticta and counting: Colombia as a hot spot for unrecognized diversification in a conspicuous macrolichen genus. Phytotaxa 74: 1-29.

Moncada, B., Betancourt, L. \& Lücking, R. (2012a) Diversity and phylogeny of the genus Lobariella ( $L O-$ bariaceae). In Abstracts of the 7th IAL Symposium, 913 fanuary 2012, Bangkok, Thailand, p. 160.

Moncada, B., Lücking, R., Parmnen, S. \& Lumbsch, H. T. (2012b) Sticta fuliginosa (Lobariaceae): species or morphotype? In Abstracts of the 7th IAL Symposium, 9-13 fanuary 2012, Bangkok, Thailand, p. 159.

Nylander, W. (1860) Synopsis Methodica Lichenum Omnium Hucusque Cognitorum Praemissa Introductione Lingua Gallica Tractata. Paris: Martinet.

Nylander, W. (1875) Addenda nova ad Lichenographiam Europaeam. Continuatio secunda et vicesima. Flora 58: 358-365.

Orange, A., James, P. W. \& White, F. J. (2001) Microchemical Methods for the Identification of Lichens. London: British Lichen Society.

Penn, O., Privman, E., Ashkenazy, H., Landan, G., Graur, D. \& Pupko, T. (2010a) GUIDANCE: a web server for assessing alignment confidence scores. Nucleic Acids Research 38: W23-W28.

Penn, O., Privman, E., Landan, G., Graur, D. \& Pupko, T. (2010b) An alignment confidence score capturing robustness to guide-tree uncertainty. Molecular Biology and Evolution 27: 1759-1767.

Remane, R. \& Holzinger, W. (1995) Zygina hypermaculata nov. spec., eine neue Zwergzikade aus dem Ostalpenraum (Homoptera, Auchenorrhyncha: $\mathrm{Ci}$ cadellidae). Carinthia II 185/105: 713-721.

Ryan, B. D. \& Galloway, D. J. (2002) Pseudocyphellaria. In Lichen Flora of the Greater Sonoran Desert Region, Volume I (T. H. Nash III, B. D. Ryan, C. Gries \& F. Bungartz, eds): 413-415. Tempe, Arizona: Lichens Unlimited, Arizona State University.

Sato, H., Kawakami, H., Hara, H., Komine, M., Takahashi, Y., Yamamoto, Y. \& Yoshimura, I. (2011) Materials for the study of distributions of lichenized fungi (27). Lobaria sachalinensis. Lichenology 10: 6770.

Schumm, F. (2003) Die Flechtengattung Lobaria auf Madeira. Herzogia 16: 91-112.

Spielmann, A. A. (2009) Estudos Taxonômicos em Parmotrema s. l. (Parmeliaceae, Ascomycota Liquenizados) com Ácido Salazínico. São Paulo: Instituto de Botânica da Secretaria de Estado do Meio Ambiente. 
Stamatakis, A. (2006) RAxML-VI-HPC: maximum likelihood-based phylogenetic analyses with thousands of taxa and mixed models. Bioinformatics 22: 2688-2690.

Stamatakis, A., Hoover, P. \& Rougemont, J. (2008) A fast bootstrapping algorithm for the RAxML webServers. Systematic Biology 57: 758-771.

Stenroos, S., Stocker-Wörgötter, E., Yoshimura, I., Myllys, L., Thell, A. \& Hyvönen, J. (2003) Culture experiments and DNA sequence data confirm the identity of Lobaria photomorphs. Canadian fournal of Botany 81: 232-247.

Suárez, A. \& Lücking, R. (2013) Sticta viviana (lichenized Ascomycota: Peltigerales: Lobariaceae), a new species from Colombian paramos. Lichenologist 45 (in press).

Takahashi, K., Wang, L.-S., Tsubota, H. \& Deguchi, H. (2006) Photosymbiodemes Sticta wrightii and Dendriscocaulon sp. (lichenized Ascomycota) from Yunnan, China. Fournal of the Hattori Botanical Laboratory 100: 783-796.

Thomas, M. A., Ryan, D. J., Farnden, K. J. F. \& Galloway, D. J. (2002) Observations on phylogenetic relationships within Lobariaceae Chevall. (Lecanorales, Ascomycota) in New Zealand, based on ITS-5.8s molecular sequence data. Bibliotheca Lichenologica 82: 123-138.

Thompson, J. D., Higgins, D. G. \& Gibson, T. J. (1994) Clustal W: improving the sensitivity of progressive multiple sequence alignment through sequence weighting, position-specific gap penalties and weight matrix choice. Nucleic Acids Research 22: 4673-4680.

Tønsberg, T. \& Goward, T. (2001) Sticta oroborealis sp. nov. and other Pacific North American lichens forming dendriscocauloid cyanotypes. Bryologist 104: 12-23.

Vainio, E. A. (1890) Etude sur la classification et la morphologie des lichens du Brésil, I. Acta Societatis pro Fauna et Flora Fennica 7: V-XXIX, 1-247.

Vilgalys, R. \& Hester, M. (1990) Rapid genetic identification and mapping of enzymatically amplified ribosomal DNA from several Cryptococcus species. Fournal of Bacteriology 172: 4238-4246.

White, T. J., Bruns, T. D., Lee, S. \& Taylor, J. (1990) Amplification and direct sequencing of fungal ribosomal RNA genes for phylogenetics. In PCR Protocols (M. A. Innis, D. H. Gelfand, J. J. Sninsky \& T. J. White, eds): 315-322. San Diego: Academic Press.

Wiklund, E. \& Wedin, M. (2003) The phylogenetic relationships of the cyanobacterial lichens in the Leca- norales suborder Peltigerineae. Cladistics 19: 419431.

Wilkins, A. L. (1993) The distribution, biosynthetic and possible evolutionary inter-relationship of triterpenoids in New Zealand Pseudocyphellaria species. Bibliotheca Lichenologica 53: 277-288.

Yamamoto, Y., Hara, K., Komine, M. \& Yoshimura, I. (2005) Materials for the study of distributions of lichenized fungi (12). Lobaria kurokawae, Lobaria isidiosa and Lobaria retigera. Lichenology 4: 105-111.

Yoshimura, I. (1969) Taxonomy of Lobaria subdissecta and its allies. Fournal of the Hattori Botanical Laboratory 32: $57-66$.

Yoshimura, I. (1971) The genus Lobaria of eastern Asia. Fournal of the Hattori Botanical Laboratory 34: 231364.

Yoshimura, I. (1984) Taxonomic studies on Lobaria crenulata and its allies. Fournal of the Hattori Botanical Laboratory 57: 97-126.

Yoshimura, I. (1998a) Vainio and Lobaria, old and modern concepts. In Recollecting Edvard August Vainio (M. P. Marcelli \& T. Ahti, eds): 85-94. São Paulo, Brazil: CETESB - Companhia de Tecnologia de Saneamento Ambiental.

Yoshimura, I. (1998b) Lobaria in Latin America: taxonomic, geographic and evolutionary aspects. In Lichenology in Latin America: History, Current Knowledge and Applications (M. P. Marcelli \& M. R. D. Seaward, eds): 129-134. São Paulo, Brazil: CETESB - Companhia de Tecnologia de Saneamento Ambiental.

Yoshimura, I. (2002) Lobariella. In Lichen Flora of the Greater Sonoran Desert Region, Volume 1 (T. H. Nash III, B. D. Ryan, C. Gries \& F. Bungartz, eds): 270-272. Tempe, Arizona: Lichens Unlimited, Arizona State University.

Yoshimura, I. (2004) Lobaria. In Lichen Flora of the Greater Sonoran Desert Region, Volume 2 (T. H. Nash III, B. D. Ryan, C. Gries \& F. Bungartz, eds): 351-352. Tempe, Arizona: Lichens Unlimited, Arizona State University.

Yoshimura, I. \& Arvidsson, L. (1994) Taxonomy and chemistry of the Lobaria crenulata group in Ecuador. Acta Botanica Fennica 150: 223-333.

Zhou, S. \& Stanosz, G. R. (2001) Primers for amplification of mt SSU rDNA, and a phylogenetic study of Botryosphaeria and associated anamorphic fungi. Mycological Research 105: 1033-1044.

Zoller, S., Scheidegger, C. \& Sperisen, C. (1999) PCR primers for the amplification of mitochondrial small subunit ribosomal DNA of lichen-forming ascomycetes. Lichenologist 31: 511-516. 